\author{
UNIVERSIDADE DE SÃO PAULO \\ FACULDADE DE ECONOMIA, ADMINISTRAÇÃO E CONTABILIDADE \\ DEPARTAMENTO DE ADMINISTRAÇÃO \\ PROGRAMA DE MESTRADO PROFISSIONAL EM EMPREENDEDORISMO
}

ROGERIO MEIRELLES

GERENCIAMENTO DE RISCO CORPORATIVO E AVALIAÇÃO DA MATURIDADE EMPRESARIAL EM GERENCIAMENTO DE RISCO CORPORATIVO:

UM ESTUDO DE CASO NA AKZONOBEL.

SÃO PAULO

2018 
Prof. Dr. Vahan Agopyan

Reitor da Universidade de São Paulo

Prof. Dr. Adalberto Américo Fischmann

Diretor da Faculdade de Economia, Administração e Contabilidade

Prof. Dr. Moacir de Miranda Oliveira J'unior

Chefe do Departamento de Administração

Prof. Dr. Marcelo Caldeira Pedroso

Coordenador do Programa de Mestrado Profissional em Empreendedorismo 


\title{
ROGERIO MEIRELLES
}

\section{GERENCIAMENTO DE RISCO CORPORATIVO E AVALIAÇÃO DA MATURIDADE EMPRESARIAL EM GERENCIAMENTO DE RISCO CORPORATIVO: \\ UM ESTUDO DE CASO NA AKZONOBEL.}

\begin{abstract}
Dissertação apresentada à coordenação do Programa de Mestrado Profissional em Empreendedorismo da Faculdade de Economia, Administração e Contabilidade FEA da Universidade de São Paulo - USP para obtenção do título de Mestre em Ciências.
\end{abstract}

Área de Concentração: Empreendedorismo Orientador: Prof. Dr. Fábio Lotti Oliva

Versão Corrigida

São Paulo - SP

2018 
FICHA CATALOGRÁFICA

Elaborada por Rafael Mielli Rodrigues - CRB-8/7286

Seção de Processamento Técnico do SBD/FEA/USP

\section{Meirelles, Rogério}

Gerenciamento de risco corporativo e avaliação da maturidade empresarial em gerenciamento de risco corporativo: um estudo de caso na AkzoNobel / Rogério Meirelles. - São Paulo, 2018

$117 p$

Dissertação (Mestrado) - Universidade de São Paulo, 2018.

Orientador: Fábio Lotti Oliva.

1. Administração de risco 2. Gerenciamento de risco corporativo 3. Risco 4. Cadeia de suprimentos 5. Celulose I. Universidade de São Paulo. Faculdade de Economia, Administração e Contabilidade. II. Título. 


\section{DEDICATÓRIA}

À minha amada esposa Andréia e aos meus amados filhos Heloise, Lorenzo e Marina. Foram as mãos firmes que seguraram as lanternas, iluminando essa minha trilha desconhecida.

Aos meus pais. 



\section{AGRADECIMENTOS}

Ao Senhor Deus, pelo desenho de minha vida até esse momento e pelo amparo incondicional, e aos queridos Santos que aceitaram minha devoção.

Ao caro Prof. Dr. Fabio Lotti Oliva, que leva ao pé da letra a função de orientador, sempre referente, presente e disponível.

Aos meus amigos e familiares incentivadores dessa jornada, e em especial ao amigo Ayrton

Britto (in memorian).

À Profa ${ }^{\mathrm{a}}$. Dra . Adriana Marotti Ribeiro pelas orientações iniciais.

À AkzoNobel pela permissão concedida e pelo suporte oferecido.

Aos participantes desse estudo, que puderam compartilhar comigo seus conhecimentos.

Ninguém vence sozinho ... obrigado a todos !!! 



\section{RESUMO}

MEIRELLES, R. Gerenciamento de Risco Corporativo e Avaliação da Maturidade Empresarial em Gerenciamento de Risco Corporativo: Um Estudo de Caso na AkzoNobel. 2018. 102 p. Dissertação (Mestrado) - Faculdade de Economia, Administração e Contabilidade (FEA) da Universidade de São Paulo (USP), São Paulo, 2018.

Esse estudo de caso reflete uma situação percebida pelo autor, alcançada durante a pesquisa para composição dessa dissertação, de que no Brasil o gerenciamento de risco corporativo ainda é pouco incorporado à cultura empresarial, sendo mais utilizado nas grandes empresas, nacionais ou multinacionais. Também é iniciante o reconhecimento da necessidade de o risco ser identificado, monitorado e mitigado, permeando todos os níveis da organização, incluindo o ambiente externo à montante e à jusante do processo. Nesse trabalho, o Supply Chain é o foco da atenção, com todos os seus componentes. Ainda que se adote um método de gerenciamento de risco corporativo, o nível de maturidade das empresas brasileiras em gerenciar o risco de sua atividade econômica ainda é relativamente baixo. Considerando a atuação profissional do autor como colaborador da empresa, essa dissertação propôs-se a analisar o gerenciamento de risco corporativo praticado na AkzoNobel, multinacional holandesa estabelecida no Brasil desde os anos 1960, em seu negócio local de Celulose, identificar os principais riscos de sua cadeia de valor, com foco no Supply Chain, e avaliar seu nível de maturidade no gerenciamento dos riscos aos quais está submetida.

Gerenciamento de Risco Corporativo e Avaliação de Maturidade Empresarial foram as bases conceituais acessadas, a primeira especialmente baseada em COSO, e a segunda em Oliva. O autor utilizou pesquisa bibliográfica, aplicação de questionários e estudo de caso através da análise qualitativa das respostas e da validação dos dados. Os resultados apresentados foram a análise do gerenciamento de risco corporativo praticado pela organização, a identificação dos principais riscos aos quais se submete e a avaliação da maturidade empresarial da organização.

As conclusões obtidas foram a avaliação do gerenciamento de risco corporativo praticado pela empresa e a avaliação do grau de maturidade empresarial da organização em gerenciamento de risco corporativo.

Palavras-chave: Administração de Risco, Gerenciamento de Risco Corporativo, Risco, Maturidade Empresarial, Supply Chain, Celulose. 


\begin{abstract}
MEIRELLES, R. Corporate Risk Management and Business Maturity Evaluation in Corporate Risk Management: A Case Study in AkzoNobel. 2018. 102 p. Dissertation (Master Degree) - School of Economy, Administration and Accounting in São Paulo University (USP - Universidade de São Paulo), São Paulo, 2018.
\end{abstract}

This case study reflects a situation perceived by the author, during the research for the composition of this dissertation, that in Brazil corporate risk management is still barely incorporated into the corporate culture, being more used in large companies, national or multinational. The recognition of the need for identify, monitore and mitigate risk, permeating all levels of the organization, including the external environment upstream and downstream of the process, is also in its first steps. In this work, the Supply Chain is the focus of attention, with all its components. Even if a method for corporate risk management is in place, the maturity level of Brazilian companies in managing the risk of their economic activity is still relatively low. Considering the professional acting of the author as a collaborator of the company, this dissertation proposed to analyze the corporate risk management practiced in AkzoNobel, a Dutch multinational established in Brazil since the 1960s in its local business of Cellulose, to identify the main risks of its supply chain, and evaluate its maturity level in the management of the risks to which it is submitted.

Corporate Risk Management and Business Maturity Assessment were the conceptual bases accessed, the first especially based on COSO, and the second on Oliva. The author used bibliographic research, application of questionnaires and case study through the qualitative analysis of the answers and the validation of the data. The results presented were the analysis of corporate risk management practiced by the organization and the evaluation of the organization business maturity level.

The conclusions obtained were the evaluation of the corporate risk management model practiced by the company and the assessment of corporate maturity in corporate risk management. The conclusions obtained resulted in the evaluation of risk management practiced by the company and in the evaluation of organization business maturity level.

Keywords: Risk Management, Corporate Risk Management, Risk, Business Maturity, Supply Chain, Cellulose. 


\section{SUMÁRIO}

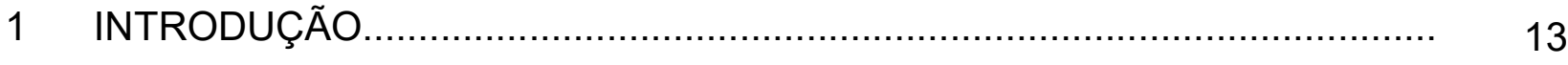

1.1 Definição da Situação Problema ………………………….............. 15

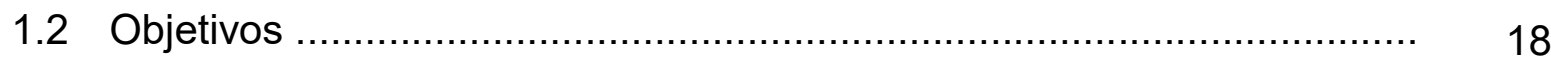

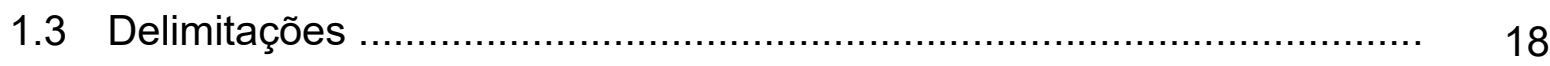

1.4 Justificativas e Contribuições ....................................................... 19

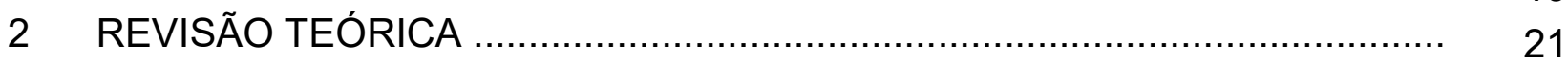

2.1 Análise e Caracterização do Risco …………................................... 21

2.2 Avaliação do Risco Corporativo .................................................... 25

2.3 Gerenciamento de Risco Corporativo ……........................................ 27

2.3.1 Abordagem COSO - Comittee of Sponsoring Organizations of Treadway Commission (Comitê das Organizações Patrocinadoras da Comissão Treadway) ......

2.3.2 Abordagem ABNT - Associação Brasileira de Normas Técnicas (2009), através da ISO:31.000 ................................. 31

2.3.3 Abordagem Nohara et al. (2005) …….................................... 33

2.3.4 Comparação das Abordagens COSO (2013) x ABNT ISO (2009) x Nohara et al. (2005) e Justificativa da Adoção de Gerenciamento de Risco Corporativo Proposto para o Caso.....

2.4 Avaliação de Maturidade em Gerenciamento de Risco Corporativo .......

2.4.1 Abordagem de Poltronieri (2014) ....................................... 37

2.4.2 Abordagem de Oliva (2016) ............................................. 40

2.4.3 Abordagem de Hillson (1997) ............................................ 44

2.4.4 Comparação das Abordagens Poltronieri (2014) x Oliva (2016) x Hillson (1997) e Justificativa da Adoção de Modelo de Avaliação de Maturidade Proposto para o Caso

3.1 A empresa estudada: A AkzoNobel no Brasil..................................... 53

3.2 Cadeia de Valor da Indústria de Celulose ........................................ 55

3.2.1 Fatores de Risco para Monitoramento na Cadeia de Valor da Celulose

3.3 O negócio de Celulose no Brasil .................................................... 58

4 MÉTODOS E TÉCNICAS .................................................................. 61

4.1 Justificativa para a Escolha pelo Método de Pesquisa Qualitativa.......... 62

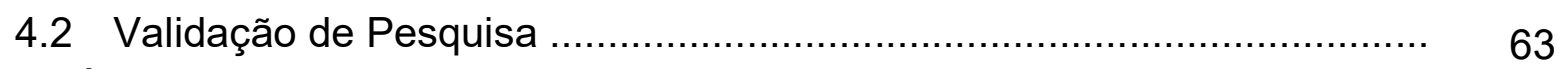

$5 \quad$ ANÁLISE DOS DADOS .................................................................... 67

5.1 Gerenciamento do Risco Corporativo e Avaliação de Maturidade na AkzoNobel

5.1.1 Gerenciamento de Risco Corporativo na AkzoNobel ................... 67

5.1.1.1 Avaliação de Risco ................................................. 68

5.1.1.2 Plano de Ação de Mitigação de Riscos ...................... 69

5.1.1.3 Análise de Portfólio ............................................... 70

5.1.2 Principais Tipos de Risco aos Quais a AkzoNobel Está Exposta 
5.2 Gerenciamento de Risco Corporativo - Análise das Respostas aos Questionários $\quad$ - $\quad$ Parte 1 .

5.2.1 Gerenciamento de Risco Corporativo - Comparativo com a parametrização COSO (2013) …………………………...... 76

5.2.1.1 Ambiente de Controle ……........................................ 76

5.2.1.2 Avaliação de Riscos ............................................ 77

5.2.1.3 Atividades de Controle ......................................... 77

5.2.1.4 Informação e Comunicação ...................................... 78

5.3 Avaliação de Maturidade Empresarial - Análise das Respostas aos Questionários $\quad$ - $\quad$ Parte 2

5.4 Gerenciamento de Risco Corporativo e Avaliação de Maturidade Empresarial - Análise dos Dados Conclusões

5.4.1 Gerenciamento de Risco Corporativo

5.4.2 Avaliação de Maturidade

6 FIGURA DA ORGANIZAÇÃO

7 CONCLUSÃO

7.1 Objetivos

7.1.1 Objetivo Geral

7.1.2 Objetivos Específicos

7.2 Implicações Gerenciais

7.3 Processo Metodológico 90

7.4 Delimitações 90

7.5 Aplicações Futuras 91

7.6 Considerações Finais .

REFERÊNCIAS

91

92

93

CRONOGRAMA 99

GLOSSÁRIO

ANEXOS

01 Figura llustrativa do Conceito de llha Química

102

02 coso Internal Controls - Integrated Framework Principles - One Page ......................................

03 Modelo de Hillson (1997) - Atributos dos 4 Níveis de Maturidade de Risco (Tradução livre do autor) ....

04 Enterprise Risks In The Environment Of Value - Oliva (2016) - $\quad$ Figura $\quad$ Original

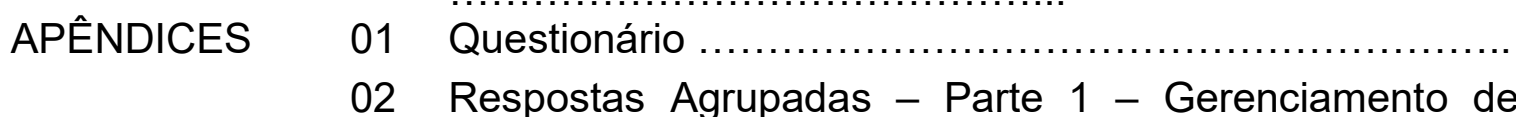
Risco Corporativo

03 Respostas Agrupadas - Parte 2 - Avaliação de Maturidade 


\section{LISTA DE FIGURAS E TABELAS}

Figura 01..... Classificação dos 29 Destruidores de Valor

Figura 02...... Antídoto para os Destruidores de Valor

Figura 03..... Exemplo de Caracterização de Riscos

Figura 04..... Exemplo de Caracterização de Riscos - Matriz Adaptada

Figura 05..... Avaliação de Risco Corporativo - Matriz de Probabilidade $\mathrm{x}$ Impacto Adaptada

Figura $06 \ldots . .$.

Relação entre Objetivos e Componentes - Cubo COSO ................

Figura $07 \ldots . .$.

coso Internal Controls - Integrated Framework Principles

Figura $08 \ldots . .$.

Relacionamento entre os Princípios, Estrutura e Processo de Gestão de Riscos

Figura $09 \ldots . .$. Modelo de Gerenciamento de Risco Integrado

Figura $10 \ldots . .$. Comparativo entre as Abordagens COSO (2013) x ABNT ISO (2009) x Nohara et al. (2005)

Figura 11..... Sumário do Modelo de Avaliação de Maturidade proposto em Poltronieri (2014)

Figura 12..... Riscos Empresariais no Ambiente de Valor - Tradução Livre do Autor

Figura 13..... Nível de Maturidade no Gerenciamento de Risco Empresarial .......

Figura 14..... Demonstrativo de Agrupamento de Risco - Poltronieri (2014) x Oliva (2016) x Hillson (1997)

Figura 15..... Comparação de Escalas para Avaliação do Grau de Maturidade Poltronieri (2014) x Oliva (2016) x Hillson (1997) ..........................

Figura $16 \ldots . .$.

Figura $17 \ldots . .$.

Figura $18 \ldots . . .$.

Estrutura Comercial da AkzoNobel no Brasil

Cadeia de Valor da Indústria de Celulose

Cadeia de Valor da Celulose - Composição de Custo - Fatores de Risco para Monitoramento

Figura $19 \ldots . .$.

Celulose no Brasil - Exportação e Produção ...

Figura $20 .$. Fluxo de Gerenciamento de Risco Corporativo da AkzoNobel ......

Análise de Portfólio

Figura 22..... Riscos Empresariais no Ambiente de Valor - Grupos Respondentes do Questionário

Figura 23..... Avaliação de Maturidade da Organização conforme Oliva (2016) .

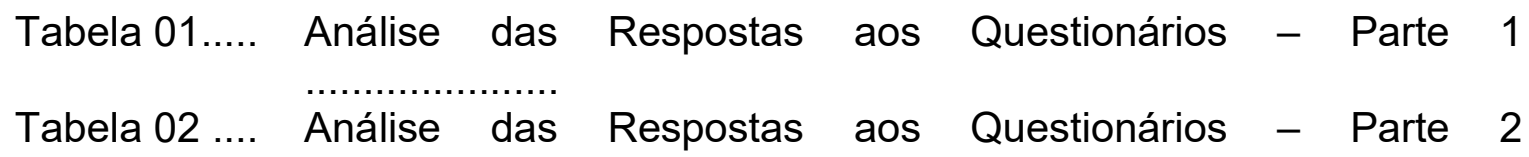





\section{INTRODUÇÃO}

Organizações de todos os tipos e tamanhos enfrentam influências e fatores internos e externos que tornam incerta a estimativa do momento em que elas atingirão seus objetivos. O efeito que essa incerteza tem sobre os objetivos da organização é chamado de "risco". (ABNT ISO:31.000, 2009).

Além das obrigações legais de estabelecer procedimentos precisos e rigorosos de controle dos riscos inerentes às suas atividades, criadas a partir de 2007 e 2008, quando mundialmente revelaram-se fraudes em empresas financeiras e não financeiras (Ferro, 2015), gerenciar e mitigar o risco e zelar pela maturidade empresarial são práticas que podem garantir a continuidade do negócio e a própria perenidade da empresa. A adoção de uma metodologia garante a uniformidade das ações e um trabalho contínuo e evolutivo nessas áreas. Consultorias como Deloitte (2005) possuem expertise nesse mercado, e pesquisadores acadêmicos e profissionais de mercado tem se debruçado ao longo dos anos sobre esse campo do conhecimento, destacadamente no campo de finanças, mas aos poucos estendendo os estudos a outras áreas como a industrial. Baseado no estudo da Deloitte (2005), em seu artigo Risks and strategies in a Brazilian innovation - flexfuel technology, Oliva et al. (2014 p.919) aponta os 15 principais riscos aos quais estão expostas as corporações, divididos em 4 categorias. No campo de Riscos Estratégicos, aponta: redução de demanda; problemas com clientes e insolvência, problemas com fusões e aquisições; pressões por preços e riscos de regulamentação. Na categoria de Riscos Operacionais identifica custos operacionais não controlados; problemas contábeis; problemas de logística; não conformidade com regulamentos e elevação de custos. Na categoria de Riscos Financeiros identifica altas taxas de endividamento e taxas de juros e estratégias financeiras fracas. Por fim, na categoria de Riscos Externos aponta crises no setor da empresa; problemas econômicos no país-sede e exposição a vulnerabilidades legais. ${ }^{1}$

\footnotetext{
${ }^{1}$ Tradução livre: “...(1) strategic risks: 1, demand reduction; 2, problems with clients and insolvency; 3, problems with mergers and acquisitions; 4, pressures by price; 5, regulatory; (2) operational risks: 6, uncontrolled operating costs; 7 , accounting problems; 8 , problems of logistics; 9, non-conformity with regulations; 10, elevation of costs; (3) financial risks: 11, high rates of indebtedness and interest rates; 12, financial strategies weak; and (4) external risks: 13, crises in the sector of the company; 14, economic problems inthe host country; 15, vulnerabilities legal."
} 
COSO (Committe of Sponsoring Organizations) of the Treadway Comission (2007) entrega um importante material ao mercado, assim como a ABNT (Associação Brasileira de Normas Técnicas) através da ABNT ISO:31.000 - Gestão de Riscos Princípios e Diretrizes (2009). Caracterizada portanto a importância do Gerenciamento de Risco, ao qual se pode acrescentar a definição do IBGC (2017, p.14) : "O gerenciamento de riscos corporativos (GRCorp) pode ser entendido como um sistema intrínseco ao planejamento estratégico de negócios, composto por processos contínuos e estruturados - desenhados para identificar e responder a eventos que possam afetar os objetivos da organização - e por uma estrutura de governança corporativa responsável por manter esse sistema vivo e em funcionamento. Por meio desses processos, a organização pode mapear oportunidades de ganhos e reduzir a probabilidade e o impacto de perdas. Trata-se, portanto, de um sistema integrado para conduzir o apetite à tomada de riscos no ambiente de negócios, a fim de alcançar os objetivos definidos."; esse estudo aborda também a Avaliação da Maturidade Empresarial.

Tão importante quanto gerenciar os riscos é evoluir no modelo adotado, através de revisões cíclicas e avaliação da maturidade empresarial em gerenciamento de risco corporativo. Assim, esse estudo visitou diferentes abordagens como Poltronieri (2014), Oliva (2016) e Hillson (1997), nas quais a Avaliação de Maturidade Empresarial é utilizada como medida de evolução do Gerenciamento de Risco Corporativo de uma organização.

O setor de Celulose depara-se, em toda sua cadeia, com questões desse tipo, que precisam do suporte geral das teorias e metodologias, mas que também demandam respostas direcionadas aos riscos do setor. Esse trabalho propõe analisar, como estudo de caso, o gerenciamento de risco corporativo da AkzoNobel em seus negócios no setor de Celulose, e avaliar seu grau de maturidade empresarial em gerenciamento de risco corporativo. 


\subsection{Definição da Situação Problema}

"O Risco, como medida de incerteza, inclui fatores que podem facilitar ou prevenir o atingimento das metas organizacionais." (Oliva, 2016, p. 68)2.

Oliva (2016) cita o estudo "Destruidores de Valor" da Deloitte (2005), pontuando importantes considerações. O acesso direto ao estudo permite mais contato com essas análises, realizadas no período de 1994 a 2003, quando quase metade das 1.000 maiores empresas mundiais perdeu valor de ações, em casos que chegaram à ordem de $20 \%$ de perda, conforme medição do Morgan Stanley Capital Internacional (MSCI). Embora as circunstâncias causadoras pudessem ser peculiares a cada uma das empresas avaliadas, há razões comuns e constantes que explicam esses episódios, associados a fatores de risco que incidiram negativamente sobre essas empresas na atração de investimentos. Nesse grupo, das 100 empresas que sofreram as maiores perdas no período, $80 \%$ foram expostas a mais de um tipo de risco. Numa abrangente análise que incluiu documentos públicos, notícias veiculadas pela imprensa e relatórios analíticos sobre as empresas, a Deloitte (2005) identificou 29 fatores de risco, que chamou de "Destruidores de Valor". Classificou os 29 fatores em 4 categorias, utilizando uma estrutura de riscos empregada no mercado, a estrutura COSO (Committe of Sponsoring Organizations) of the Treadway Comission - (Comitê das Organizações Patrocinadoras) da Comissão Treadway (2007). Os riscos foram divididos em:

- Estratégicos (8 riscos);

- Operacionais (8 riscos);

- Financeiros (4 riscos);

- Externos (9 riscos), conforme detalhado na figura a seguir.

2 Tradução livre: " ... risk is considered to be a measure of uncertainty and includes factors that may facilitate or prevent the achievement of the organizational goals." - 
Figura 01: Classificação dos 29 Destruidores de Valor

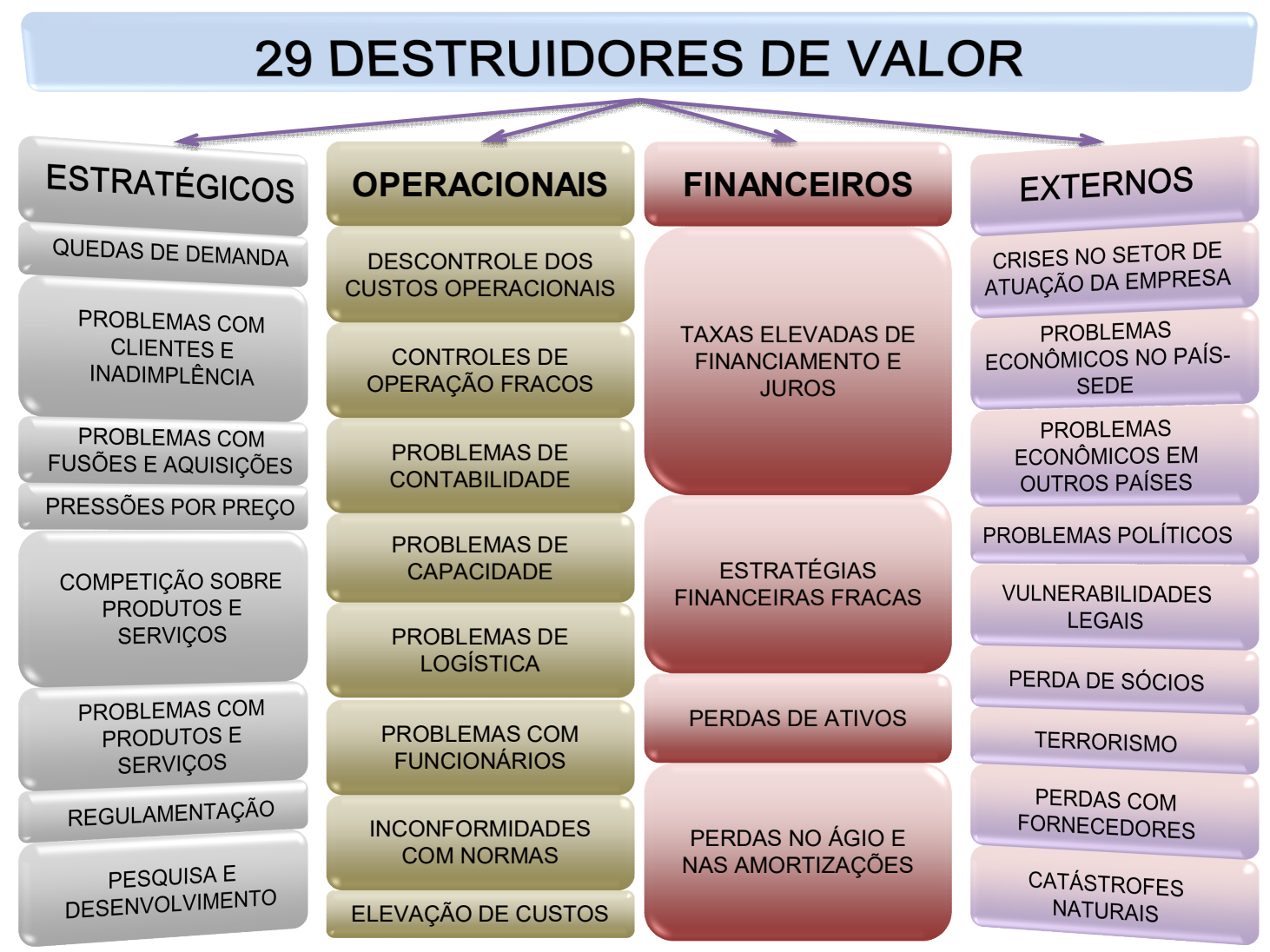

Fonte: adaptado de Deloitte (2005)

Como se vê na Figura 01, os Riscos Estratégicos são ocorrências como baixas de demanda do mercado por produtos e serviços da empresa, falhas ou atraso na reação ao movimento dos concorrentes ou problemas relacionados a fusões e aquisições. Os Riscos Operacionais são ocorrências como aumentos dos custos ou problemas na contabilidade, causados por falhas em controles internos e na logística. Os Riscos Financeiros dizem respeito a ocorrências como endividamento elevado, reservas inadequadas para controlar aumentos nas taxas de juros, administração financeira fraca e perdas nas negociações; e os Riscos Externos são crises vivenciadas pelo setor de atuação da empresa, conjunturas política e econômica, atos pontuais (como terrorismo, por exemplo) e problemas de saúde pública.

Algumas empresas estabelecidas no Brasil adotam modelos de avaliação de risco corporativo, mas essa não é a prática mais comum. A depender de seu porte, a avaliação de risco corporativo é desestruturada, e muitas vezes intuitiva ou empírica. $O$ conhecimento teórico disponível é muito mais direcionado a empresas financeiras. 
O estudo da Deloitte (2005) aponta também medidas que são "antídotos" para os riscos (ou destruidores de valor), com ações sugeridas para mitigação dos riscos.

Figura 02: Antídoto para os Destruidores de Valor

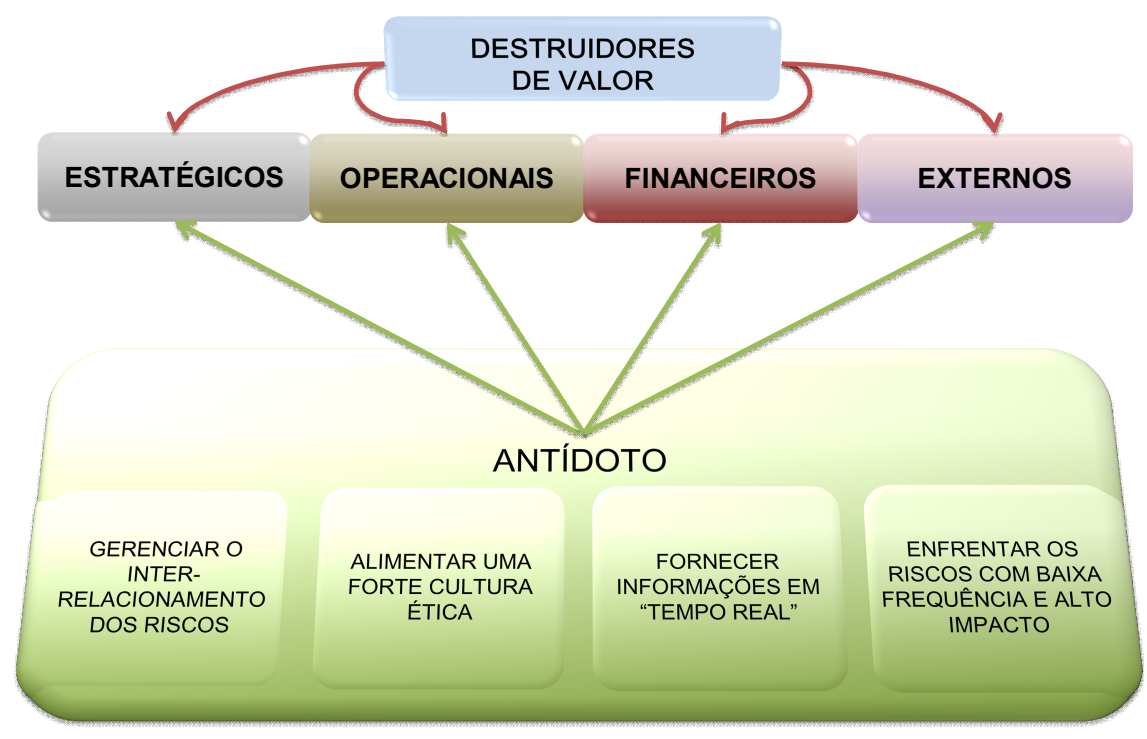

Fonte: adaptado de Deloitte (2005)

Conforme demonstrado na Figura 02, ao Gerenciar o Inter-Relacionamento dos Riscos, a empresa precisa adotar uma gestão integrada para identificar e administrar as correlações entre todos os riscos aos quais ela está exposta. Ao Alimentar uma Forte Cultura Ética, a administração da empresa tem que criar uma cultura que enfatize sua importância como organização, o controle de qualidade e o gerenciamento de risco corporativo. Incentivos de remuneração devem ser alinhados com a criação de valores em longo prazo e com a proteção à marca. Fornecer Informações em "Tempo Real" determina que a empresa precisa implantar sistemas de informações internos e mecanismos de comunicação para assegurar que a Diretoria Executiva e o Conselho de Administração recebam informações corretas, em tempo adequado, sobre as causas e os impactos financeiros, bem como as possíveis soluções para os problemas. Por fim, Enfrentar os Riscos com Baixa Frequência e Alto Impacto direciona a empresa a empregar "testes de estresse" para assegurar que os controles internos e os planos para a continuidade dos negócios possam resistir a um evento de alto impacto ou, pelo menos, dar flexibilidade para responder rapidamente a cenários adversos. 
Assim, o problema resume-se à existência dos riscos e à não adoção de um método adequado para gerenciá-los. O problema é extensivo à AkzoNobel, no seu negócio de Celulose, que possui gerenciamento de riscos não ancorado metodologicamente e não possui modelo de avaliação de maturidade.

\subsection{Objetivos}

Esse trabalho é voltado para uma compreensão ampla do gerenciamento de risco corporativo e para o estudo de caso em uma organização específica e em negócio específico, aos quais o autor, como colaborador da empresa, tem acesso.

O objetivo geral do estudo é analisar o gerenciamento de risco corporativo praticado na empresa AkzoNobel, em seu negócio de Celulose no Brasil, e os objetivos específicos são identificar os principais riscos corporativos na cadeia de valor, com foco em Supply Chain e avaliar o nível de maturidade da empresa no gerenciamento de risco corporativo.

\subsection{Delimitações}

Os riscos estudados dizem respeito ao Supply Chain, e a análise foi restrita à AkzoNobel Brasil, em seu negócio de Celulose. Supply Chain compreende os processos de Venda, Planejamento, Compras, Operações e Logística. A sequência considerada é: (a) A ocorrência de uma Venda; (b) A entrada dessa venda no Planejamento, com a sequente explosão em necessidades de Produção e Compras; (c) A colocação de um Pedido de Compra para aquisição das necessidades detectadas e a colocação de uma Ordem de Produção para produção das necessidades detectadas; (d) Realização da Compra conforme Pedidos Colocados; (e) Realização da Produção conforme Ordens colocadas; (f) Transporte inbound das Compras realizadas e transporte outbound da Produção realizada.

A análise resultante poderá vir a ser utilizado por empresas brasileiras do ramo químico, de produção contínua e de grande porte, de modo a amparar estudos similares. 


\subsection{Justificativas e Contribuições}

"As consequências negativas, sob o ponto de vista das perdas causadas às empresas, à sociedade e ao poder público, decorrentes da ausência de uma visão proativa e preventiva de riscos, e a possibilidade de modificar essa situação, por intermédio de um modelo estruturado, que senão elimine, pelo menos atenue de forma substancial os efeitos adversos dos riscos, são os grandes fatores motivadores e justificadores para se estudar riscos. Os benefícios provenientes de uma abordagem metodologicamente estruturada através de um modelo de gerenciamento de risco corporativo é o maior agente motivador, justificador e incentivador para tal empreitada." (Rovai, 2005, p. 24). Quando se fala em Gerenciamento de Risco Corporativo e Avaliação de Maturidade, percebe-se que o desenvolvimento de tais atividades no mercado brasileiro ainda é incipiente. Em seu estudo o autor identificou sólida literatura direcionada às áreas financeira e de projetos, mas pouca literatura voltada para a cadeia industrial. O foco de uma organização é produzir e vender sua produção, mas a exposição ao risco pode comprometer irremediavelmente a continuidade de uma empresa. No contexto organizacional, portanto, faz sentido dizer, como citado em Risks and strategies in a Brazilian innovation - flexfuel technology, que "o gerenciamento de risco permite compreender as incertezas e, consequentemente, desenvolver estratégias para prevenir ameaças e aproveitar oportunidades." (Oliva et al., 2014, p. 919. $)^{3}$

A importância de abordar o tema é a constatação de que riscos existem, e que as empresas muitas vezes não adotam métodos adequados para gerenciá-lo. Tal situação está no mercado e reflete-se na organização.

O autor realiza sua atividade profissional nas áreas fabris química e petroquímica há aproximadamente 30 anos, com foco em Supply Chain. Sua experiência é especialmente voltada para as áreas de Planejamento e Compras de produtivos e materiais e serviços não relacionados à produção. Em sua atuação na AkzoNobel notou pontos de melhoria na atividade de gerenciamento de risco corporativo na organização, bem como a ausência de avaliação de maturidade empresarial como complemento natural ao processo de gerenciamento de risco corporativo. Na orientação acadêmica recebida, identificou tais pontos como oportunidade para desenvolver um estudo que pudesse favorecer não somente à empresa em que atua, como outras que eventualmente venham a acessar esse

\footnotetext{
3 Tradução livre: "the risk management allows understanding the uncertainties and, consequently,
} developing strategies to preventthreats and seize opportunities." 
trabalho, ajudando-as a encarar o Gerenciamento de Risco Corporativo e a Avaliação de Maturidade Empresarial como parte integrante de seu modelo de gestão. Como contribuição, analisar o gerenciamento de risco corporativo realizado pela empresa resulta em que, ao acessar o estudo, empresas similares no ramo e em tamanho possam aprimorar seu gerenciamento de risco corporativo e sua avaliação de maturidade empresarial, colaborando com seu crescimento e com sua competitividade. Ainda como contribuição à literatura da área, e ao mesmo tempo destacando sua originalidade, apresenta dados com foco local, direcionados ao ramo de negócio e que acomodam questões específicas do Brasil. O autor contribui também com a avaliação de maturidade da empresa em gerenciamento de risco corporativo, disponibilizando análise comparativa e abordando métodos que podem ser aplicados a outras empresas.

A viabilidade do estudo foi alcançada através da metodologia utilizada, primeiro através da revisão bibliográfica dos temas Gerenciamento de Risco Corporativo e Avaliação de Maturidade Empresarial. Em seguida, a comparação entre as diversas abordagens para os dois temas, com a escolha da abordagem COSO (2013) para o Gerenciamento de Risco Corporativo e da abordagem de Oliva (2016) para a Avaliação de Maturidade Empresarial como benchmarks. As abordagens escolhidas foram utilizadas como comparativos na análise da organização, contrapondo seus parâmetros às respostas dadas pelos principais agentes do processo na cadeia de valor da organização, em resposta aos questionários aplicados em pesquisa qualitativa.

Em suma, o estudo se justifica por contemplar um estudo de caso numa grande empresa há décadas presente e adaptada à realidade brasileira, intensificar o estudo do risco corporativo e suas atividades de desdobramento num ramo da atividade industrial que se inicia nessa área, e colaborar com a literatura como fonte de conhecimento. 


\section{REVISÃO TEÓRICA}

A fundamentação baseia-se em Métodos de Gerenciamento de Risco Corporativo e Análise de Risco Corporativo em Supply Chain.

No Gerenciamento de Risco Corporativo o foco foi principalmente em Riscos Estratégicos, Operacionais, Financeiros e Externos, no estudo da ABNT ISO:31.000 (Gestão de Riscos - Princípios e Diretrizes, 2009) e na metodologia COSO (2013). Ainda, considerando a necessidade de avaliação do grau de maturidade do gerenciamento de risco adotado, foram verificados os modelos de Poltronieri (2014), a Avaliação de Risco em 4 Estágios de Hillson (1997) e o modelo de Avaliação de Maturidade de Oliva (2016).

\subsection{Análise e Caracterização do Risco}

O IBGC - Instituto Brasileiro de Governança Corporativa (2007), em estreito alinhamento com COSO (2007), traça diretrizes para Análise e Caracterização dos Riscos. Antes de mais nada a empresa deve posicionar-se quanto ao seu perfil em relação à exposição ao risco, ou, conforme a publicação, definir seu nível de apetite e tolerância a riscos, ainda que qualitativamente. Recomenda ainda, fortemente, que haja reflexo desse perfil na cultura da organização e, ainda, que "cabe ao conselho de administração outorgar um mandato claro para a diretoria administrá-lo." (IBGC, 2007, p. 16).

$\mathrm{Na}$ caracterização do risco, há dois componentes que se relacionam: "Pessoas (principalmente como causas) e Reputação (principalmente como consequência) do bom ou mau gerenciamento dos riscos" (IBGC, 2007, p.16). O componente Pessoas traz complexidade, pois está presente em todos os setores da organização. A falta de clareza na definição dos objetivos e a falha em conseguir montar um time engajado em todos os níveis prejudicam a sinergia e podem acarretar em perda do valor empresarial. Por seu lado, o componente Reputação tem maior preponderância no momento em que a consequência de um mau gerenciamento de risco se torna pública, trazendo danos reputacionais ou de imagem.

Ainda conforme o IBGC (2007), o risco precisa ser caracterizado. Pode-se partir de premissas para uma caracterização básica, que posteriormente pode vir a ser adaptada 
ao negócio. Partindo das origens dos eventos, o IBGC (2007) propõe, como exemplo, a matriz de caracterização de riscos verificada na Figura 03:

Figura 03: Exemplo de Caracterização de Riscos

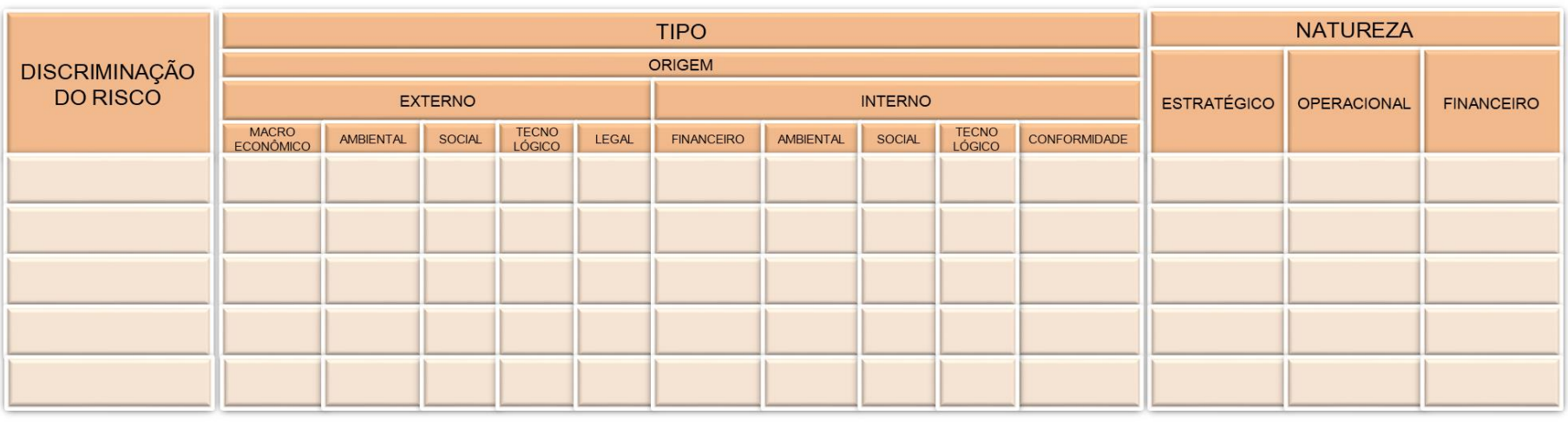

Fonte: IBGC (2007)

Na coluna Discriminação do Risco deve-se descrever o risco analisado. A Origem dos eventos (Externo ou Interno) deve ser explicitada, já que a abordagem de risco pode mudar por parte da organização. Os Riscos Externos são associados ao ambiente que rodeia a organização, produzindo necessariamente efeitos sobre sua condução, uma vez que dizem respeito ao ambiente de negócio no qual ela se insere. A organização não consegue, normalmente, intervir prontamente. Os Riscos Internos estão intramuros, restritos à organização, e a organização pode e deve intervir pró-ativamente.

Os Riscos também devem ser classificados quanto à sua Natureza. Esse cuidado permite agregá-los e tratá-los com ações organizadas. IBGC (2007) salienta que alguns riscos podem pertencer a uma ou mais categorias, ou até a todas, cabendo assim tratar com atenção esse agrupamento. Riscos Estratégicos são ligados a ações e direções da Alta Administração, mais distantes do dia-a-dia, mas potencialmente prejudiciais nos campos de finanças, mercado (incluindo fusões e aquisições), tecnologia e compliance. Os Riscos Operacionais são bem mais conectados ao dia-a dia da empresa, e dizem respeito a perdas operacionais (produção, mercado, clientes), geralmente impactando em perda de produtividade e/ou receita. Eventos externos, em determinadas circunstâncias, também podem causar impactos operacionais. Poderíamos citar catástrofes naturais, terrorismo, greves, etc. Riscos operacionais mal geridos podem impactar negativamente no rendimento das atividades e serem potenciais de danos à 
imagem ou na geração de passivos, contratuais, regulatórios e ambientais. Ainda na ótica do IBGC (2007), existem os Riscos Financeiros, conectados a mercado, crédito e liquidez. Seus impactos em caso de má gestão são sobre o fluxo de caixa da organização e das atividades a ele ligadas, como caixa operacional, retornos de transações financeiras e investimentos. A má gestão desse risco expõe a organização a endividamento elevado, juros altos e baixo retorno, podendo impactar fortemente à perenidade da companhia. Na mesma natureza financeira, a gestão temerária pode fragilizar o processo e expor a organização a fraudes.

O Risco Tecnológico pode ser de origem interna ou externa, impactando o fluxo de atividades regulares da organização, prejudicando produtividade (fisicamente) e controles de informações. Também o Risco Ambiental pode ter dupla origem, e sua má gestão pode inclusive, a depender da gravidade do descumprimento da legislação, comprometer à própria continuidade operacional. Existe ainda a hipótese de forte impacto em custos, por poder ser obrigada a arcar com remediações ambientais, além de potencial gigantesco de dano à imagem da organização. Caracteristicamente de origem interna, o Risco de Conformidade impacta à empresa quando, mal gerido, expõe a organização às regulamentações aplicáveis especificamente ao seu tipo de negócio e, ainda, permite que procedimentos internos sejam descumpridos, tornando os processos inseguros.

O autor contribui com alguns complementos. No caso de origem de risco externa, o autor acrescenta que a intervenção da empresa usualmente não é proativa, mas reativa, devido ao seu limitado poder, mesmo posicionando-se como uma das maiores empresas do mundo, no ambiente externo. Sendo uma forte influenciadora de seu segmento, pode, sim, orquestrar ações conjuntas, mas isso não ocorre sempre. Já no tocante à abrangência dos riscos de origem interna acrescenta que eles podem estar atingindo à organização como um todo, mas também podem afetar somente a subdivisões da organização, que podem ser departamentos específicos, locais específicos, etc.

Em relação a classificar os riscos quanto à sua natureza, a atitude permite um tratamento menos individualizado, portanto mais eficiente e mais abrangente. 
No tocante a Tipos, embora IBGC (2007) não se estenda detalhando os restantes, o autor gostaria de fazê-lo. Assim, o Risco Macroeconômico diz respeito ao ambiente econômico no qual a organização se insere, e não somente à sua gestão financeira. Dessa forma, crises no país sede ou nos países de instalação podem impactar suas operações financeiras. Com origem interna e externa, o Risco Social é aquele que pode impactar à organização, quando mal gerido, através de agravamentos ao contexto social existente externamente e internamente à companhia. São relativos à infraestrutura da região, incluindo aí nível de escolaridade, segurança e saneamento, e seus reflexos ao contexto interno da companhia, uma vez que seus colaboradores importam as características do ambiente. De origem externa, o Risco Legal relaciona-se à legitimidade da existência da organização como entidade, bem como o correto cumprimento de suas obrigações. Mal gerido expõe a organização a penalidades legais e pode comprometer a própria continuidade de seu funcionamento, global ou localmente.

Assim, os campos em branco da Matriz verificada na Figura 03 podem ser preenchidos de forma adaptada à realidade da organização e do momento. Pode ser um simples " $X$ " assinalando a que Natureza cada Tipo pertence, pode ser preenchido com probabilidade de impacto (Alto, Médio, Baixo), etc. O autor sugere ainda uma pequena alteração na tabela incluindo a origem "Híbrida", mesclando as origens Interna e Externa quando aplicável, como segue nessa demonstração (Figura 04). Além disso, ainda dentro da origem Híbrida, pode-se considerar a inclusão dos Riscos Microeconômico e Mercado, caso a organização em análise julgue pertinente.

Figura 04: Exemplo de Caracterização de Riscos - Matriz Adaptada 

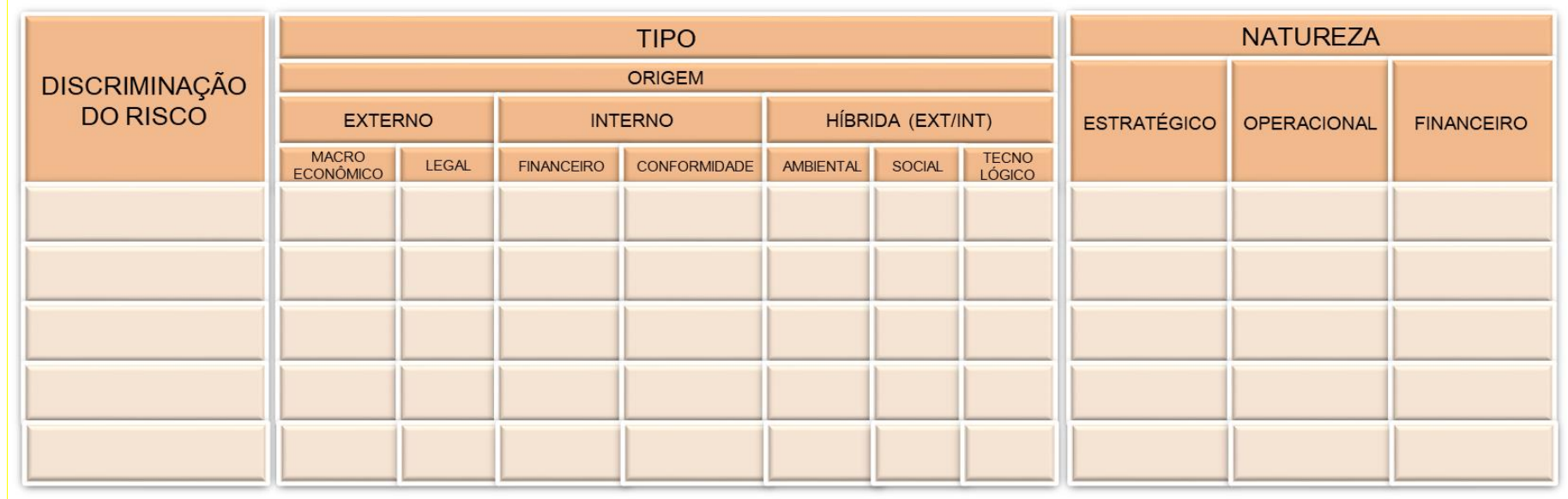

Fonte: adaptado de IBGC (2007)

\subsection{Avaliação do Risco Corporativo}

Uma vez identificado, analisado e caracterizado, o risco corporativo precisa ser avaliado. O primeiro passo deverá ser a determinação do grau de exposição da empresa ao risco. A literatura consultada direciona essa análise para dois vetores: Probabilidade de Ocorrência e Impacto da Ocorrência sobre a organização, caso se verifique. IBGC (2007) alerta para que se atente a uma possível interdependência entre um ou mais riscos, e que se avalie se um risco pode gerar não apenas um único impacto, mas múltiplos, ou seja, efeitos diferentes em diversas áreas.

Como não existe um modelo unicamente aceito, mas vários similares, o autor apresenta aqui uma Matriz de Probabilidade baseada nas várias referências consultadas. Verificar Figura 05: 
Figura 05: Avaliação de Risco Corporativo - Matriz de Probabilidade x Impacto Adaptada

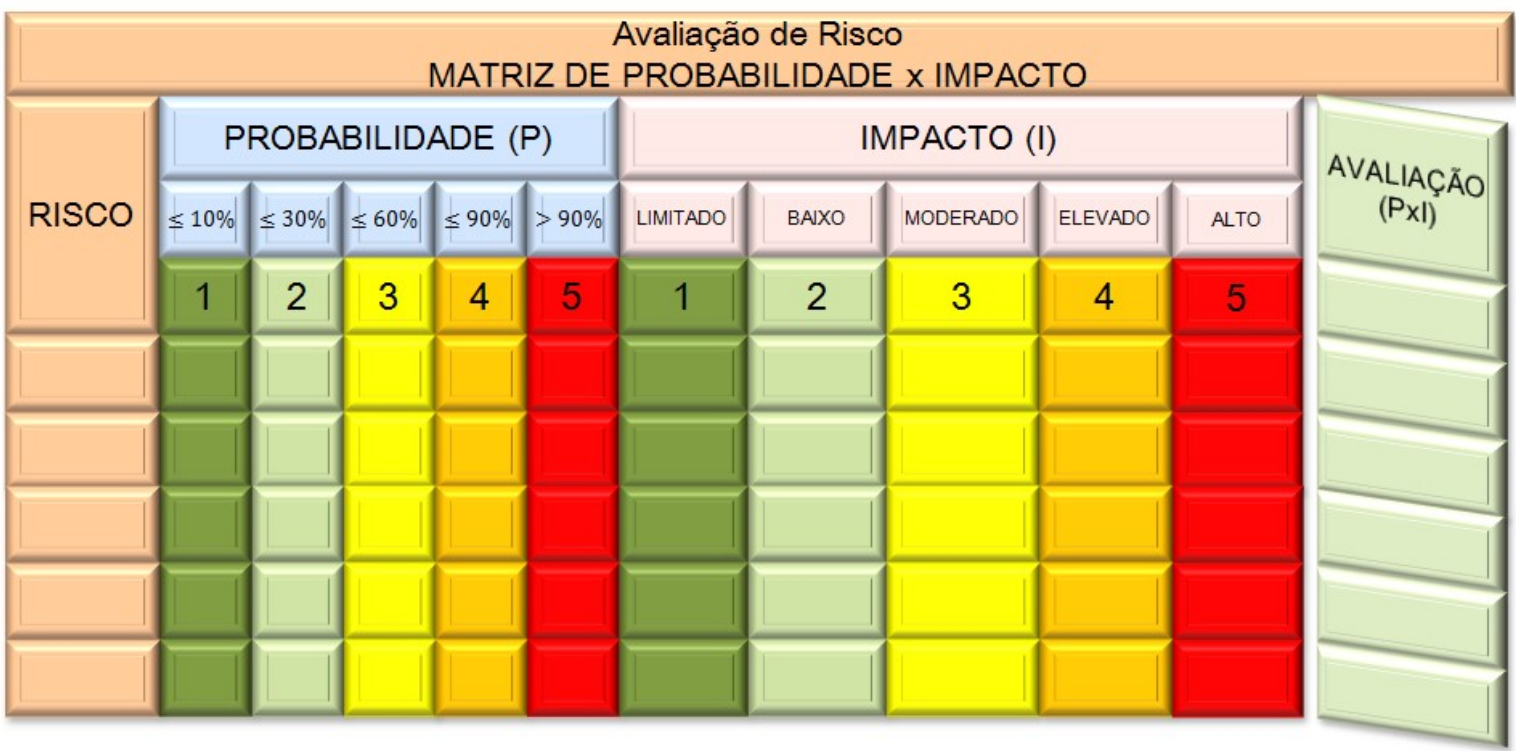

Fonte: autoria própria (2018), com base em IBGC (2007) e Project Management Institute (2014)

Tal figura pode, e deve, ser adaptada à necessidade da organização. Para cada estimativa de Probabilidade (P) e Impacto (I) dá-se um valor de 1 a 5, considerando 1 o menor índice de P/I e 5 o maior índice de P/I. Realizada a avaliação, multiplica-se P x I na coluna Avaliação, e prioriza-se o ataque aos riscos conforme os resultados obtidos. No caso de Probabilidade, a estimativa $\leq 10 \%$, deve ser atribuída a evento que somente ocorrerá em circunstâncias específicas, geralmente fora da operação normal. A estimativa de $\leq 30 \%$, a eventos difíceis de ocorrer, mas prováveis. A estimativa de $\leq$ $60 \%$ a eventos que podem ocorrer, a de $\leq 90 \%$ que podem ocorrer sob a maioria das circunstâncias e a de $>90 \%$ deve ser atribuída a eventos que certamente ocorrerão em ocasião próxima. Quanto ao Impacto, a estimativa Limitado deve ser atribuída a impactos sobre as operações, geralmente infringindo ou contrariando leis ou normas, mas sem grandes consequências para a operação da organização como um todo. A estimativa Baixo deve ser atribuída a impactos sobre algumas atividades, incluindo aí os impactos advindos de controles internos mal realizados ou inexistentes. Limitado e Baixo, geralmente, exigem intervenção somente das camadas operacionais de decisão para serem mitigados ou resolvidos. A estimativa Moderado já deve abranger impactos sobre operações financeiras, projetos e orçamentos, e passa a demandar intervenção gerencial. A estimativa Elevado tem impactos mais significativos sobre operações 
financeiras, projetos e investimentos, impactos sobre a imagem da organização, e passam a incluir decisões da alta direção em suas mitigações ou soluções. Por fim, a estimativa Alto deve ser atribuída a impactos significativos em decisões estratégicas, financeiras, imagem, causar sanções regulatórias governamentais de alto valor e pode impedir fortemente a continuidade operacional, exigindo a intervenção do mais alto comitê diretivo da organização para solucioná-los.

\subsection{Gerenciamento de Risco Corporativo}

Identificado, analisado e avaliado, o risco corporativo precisa ser gerenciado. Há várias abordagens para o eficiente gerenciamento de risco corporativo. Considerando a abrangência internacional e o fato de que praticamente toda a literatura visitada fundamenta-se em COSO, em suas várias edições, com mais ou menos liberdade, o autor decidiu adotá-la como referencial teórico desse tema. Complementarmente, o autor também referenciou a abordagem ABNT ISO:31.000 (2009) e de Nohara et al. (2005). A primeira devido à oportuna adaptação para a realidade brasileira, e ambas devido à aderência a abordagem COSO (2013).

\subsubsection{Abordagem COSO - Comittee of Sponsoring Organizations of Treadway Commission (Comitê das Organizações Patrocinadoras da Comissão Treadway)}

É uma organização privada e independente, que busca ser leading thinking no desenvolvimento de estruturas abrangentes e no desenvolvimento de diretrizes para gerenciamento de risco corporativo, detecção e mitigação de fraudes e controles internos, para aprimorar o desempenho e governança organizacional e reduzir o alcance de ações fraudulentas nas organizações (COSO, 2013).

COSO (2013) sugere procedimentos para que se estabeleçam controles internos de riscos corporativos visando o atingimento dos objetivos organizacionais, através de conteúdo que fortalece o modelo conceitual, e que vem sendo publicado desde 1992. Trata-se de uma entidade privada formada pelas seguintes associações: American Accounting Association, American Institute of Certified Public Accountants, Financial Executives Internacional, Institute of Managements Accountants e Institute of Internal Auditors, ao qual está ligado a AUDIBRA - Instituto dos Auditores Internos do Brasil, 
através da FLAI - Federação Latino-Americana de Auditores Internos. Na página de Introdução à Edição Brasileira declara-se que "Essa publicação tem o objetivo de ser considerada como um modelo conceitual para o gerenciamento de riscos corporativos, proporcionando as diretrizes para a evolução e aprimoramento do gerenciamento de riscos e dos procedimentos para sua análise."

A publicação é rica em oferta de material, recomendando-se a leitura inicial do relatório Controle Interno - Estrutura Integrada.

A metodologia pode ser resumida na conhecida figura do cubo e no esquema OnePage que resume os princípios defendidos, como se verifica nas Figuras 06 e 07.

Figura 06: Relação entre Objetivos e Componentes - Cubo COSO

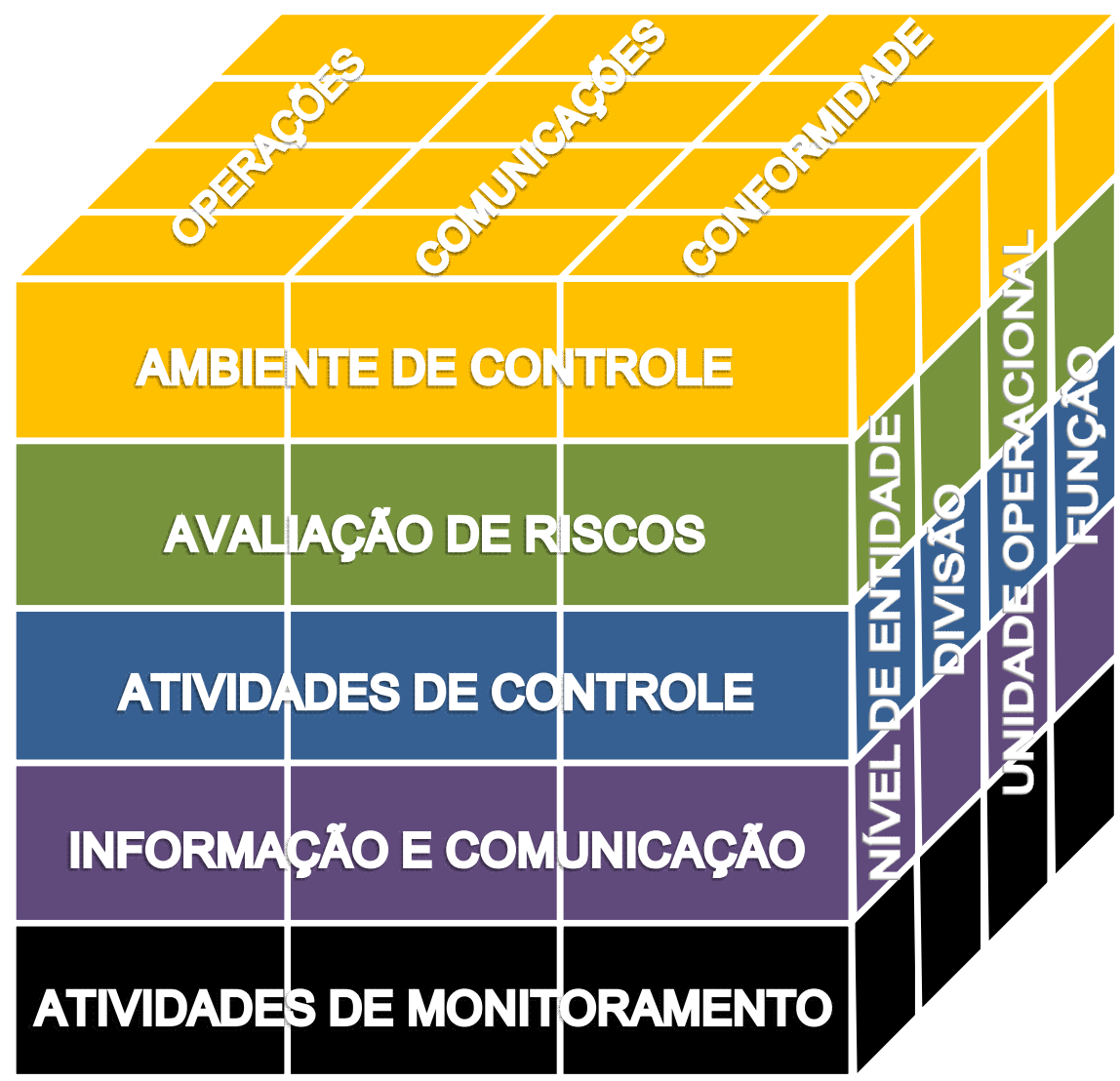

Fonte: COSO (2013)

A Figura 06 esquematiza a permeabilidade entre os Objetivos, Componentes e a estrutura organizacional da entidade. O conteúdo é muito claro quando coloca a gestão 
do risco corporativo como parte integrante das atividades da companhia em todos os seus níveis.

A face de Objetivos traz o Ambiente de Controle, que contém o detalhamento da estrutura de gerenciamento de riscos adotada pela organização; a Avaliação de Riscos, que é a forma como a organização estrutura seu gerenciamento de risco corporativo através de seus objetivos e da identificação dos riscos e seus impactos; as Atividades de Controle, que é o seu arcabouço mitigatório; Informação \& Comunicação, que é o estabelecimento de uma estrutura de coleta e organização de informações e sua correta divulgação no ambiente da empresa, e por fim traz as Atividades de Monitoramento, que é a sua estrutura de controle e melhoria contínua do processo de gerenciamento de risco corporativo.

Essa face relaciona-se com a face de Componentes, na qual Operações abrange os aspectos cotidianos da organização, realizadores da estratégia e buscadores das metas de desempenho e lucro; Comunicação abrange a coleta e organização de informações que se transformarão em instrumentos de comunicação com instâncias internas e externas, em diversas formas e mídias, dentre elas relatórios financeiros e não financeiros; e Conformidade, que abrange o alinhamento da organização às leis e regulamentos vigentes para o setor e para as localizações geográficas.

A última face, que é a estrutura organizacional da entidade, simboliza como Objetivos e Componentes são aplicados a cada uma de suas instâncias físicas (Nível de Entidade > Divisão -> Unidade Operacional -> Função).

O esquema One-Page (Figura 07), sumariza graficamente o conteúdo da metodologia. 
Figura 07: COSO Internal Controls - Integrated Framework Principles

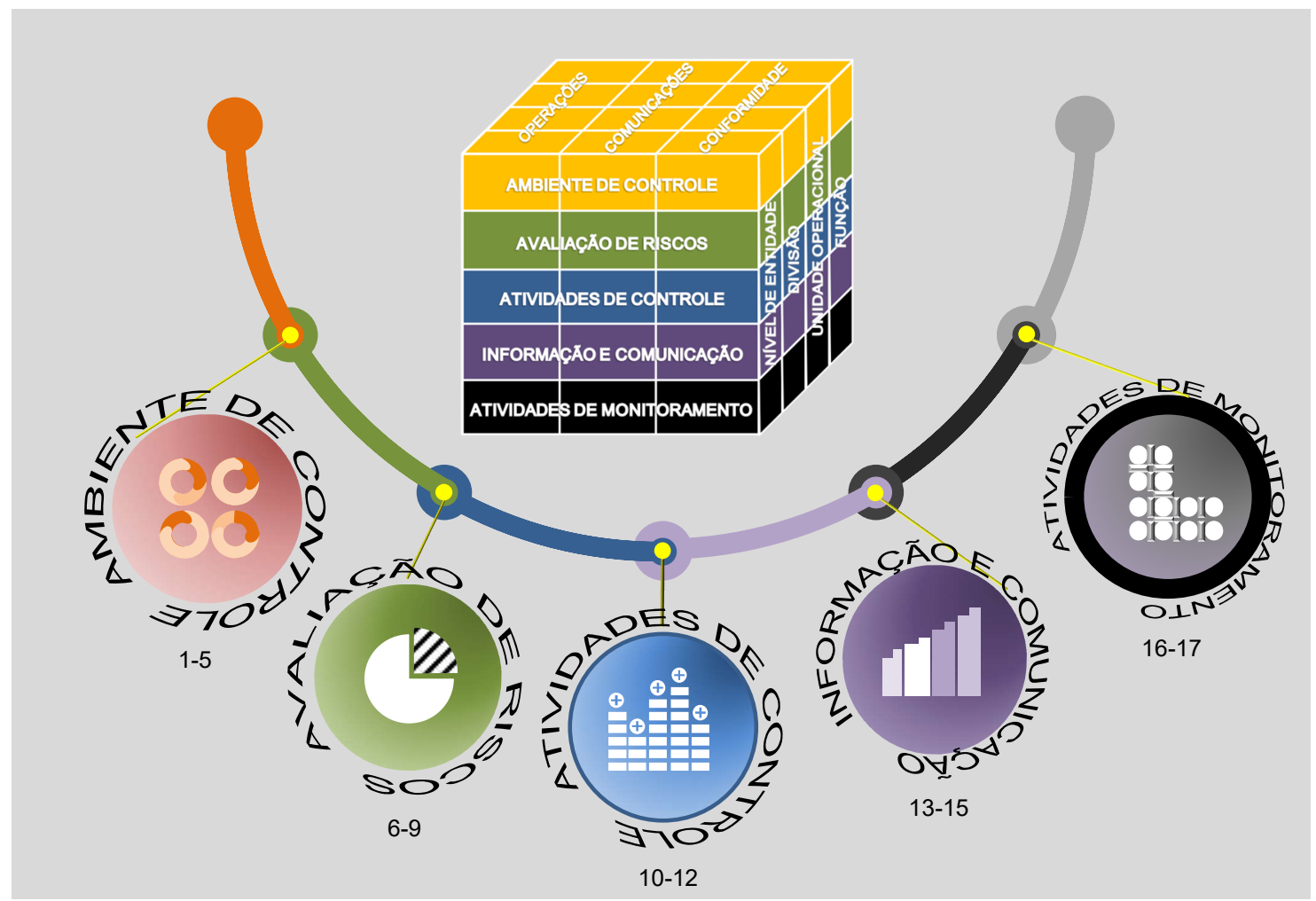

Fonte: adaptado de COSO (2013)

A figura original, em inglês, poderá ser encontrada no anexo 02 . O que se segue é uma adaptação e tradução livre do autor, uma vez que não há material disponível em português.

Os princípios trazem afirmações padrão que devem ser seguidas no momento da implementação ou revisão do gerenciamento de risco corporativo da organização.

\section{Ambiente de Controle}

1. A organização demonstra compromisso com integridade e valores éticos.

2. A Alta Direção demonstra independência da gerência e exerce supervisão sobre o desenvolvimento e desempenho dos controles internos.

3. A Administração estabelece, com supervisão da Alta Direção, estruturas, linhas de reporte, e delega autoridade e responsabilidades na busca dos objetivos.

4. A organização demonstra compromisso para atrair, desenvolver e reter profissionais competentes em alinhamento com seus objetivos.

5. A organização mantém profissionais responsáveis por seus controles internos para atingimento de seus objetivos. 


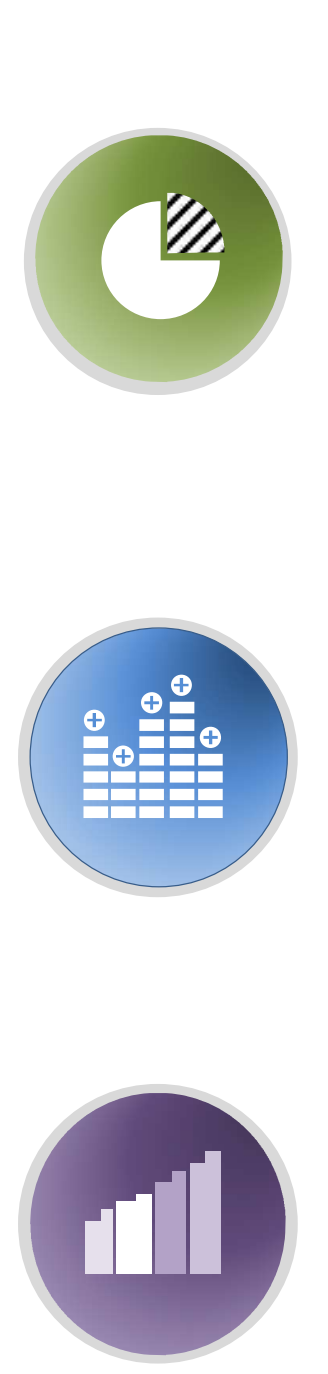

\section{Avaliação de Riscos}

6. A organização especifica seus objetivos com clareza suficiente para habilitar a identificação e avaliação dos riscos relacionados aos objetivos.

7. A organização identifica riscos no atingimento de seus objetivos através da entidade, e analisa riscos como base para determinar como devem gerenciados.

8. A organização considera fraudes em potencial quando avaliando riscos relacionados aos atingimentos dos objetivos.

9. A organização identifica e avalia mudanças que podem afetar significativamente o sistema de controles internos

\section{Atividades de Controle}

10. A organização especifica seus objetivos com clareza suficiente para habilitar a identificação e avaliação dos riscos relacionados aos objetivos.

11. A organização seleciona e desenvolve atividades gerais de controle com tecnologia, para suportar o atingimento dos objetivos.

12. A organização desdobra as atividades de controle através de políticas que estabelecem o que é esperado e procedimentos que transformam políticas em ações.

\section{Informação e Comunicação}

13. A organização obtém ou gera, e utiliza, informações de qualidade relevante para suportar a operação dos controles internos.

14. A organização divulga informações internamente, incluindo os objetivos e responsabilidades dos controles internos, necessárias para suportar sua operação.

15. A organização divulga externamente informações relacionadas a ocorrências que afetem a operação dos controles internos.

\section{Atividades de Monitoramento}

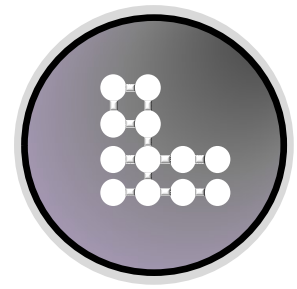

16. A organização seleciona, desenvolve e executa ações durante a operação e/ou em avaliações separadas se os componentes dos controles internos estão presentes e funcionando.

17. A organização avalia e comunica as deficiências dos controles internos de maneira oportuna às partes responsáveis por tomar ações corretivas, incluindo a Alta Gerência e a Alta Direção, se apropriado.

\subsubsection{Abordagem ABNT - Associação Brasileira de Normas Técnicas (2009), através da ISO:31.000}

A ABNT (Associação Brasileira de Normas Técnicas) publicou, em 2009, a ABNT ISO:31.000 - Gestão de Riscos - Princípios e Diretrizes, com o objetivo de sugerir uma 
padronização na metodologia de gestão de risco. Em sua análise inicial, esquematiza Gestão de Risco em Princípios, Estrutura e Processo, buscando dar uma visão de conjunto a toda a atividade. $O$ autor considera também essa uma relevante fonte de informação, especialmente considerando sua aderência à abordagem COSO (2007).

Figura 08: Relacionamentos entre os Princípios, Estrutura e Processo da Gestão de Riscos

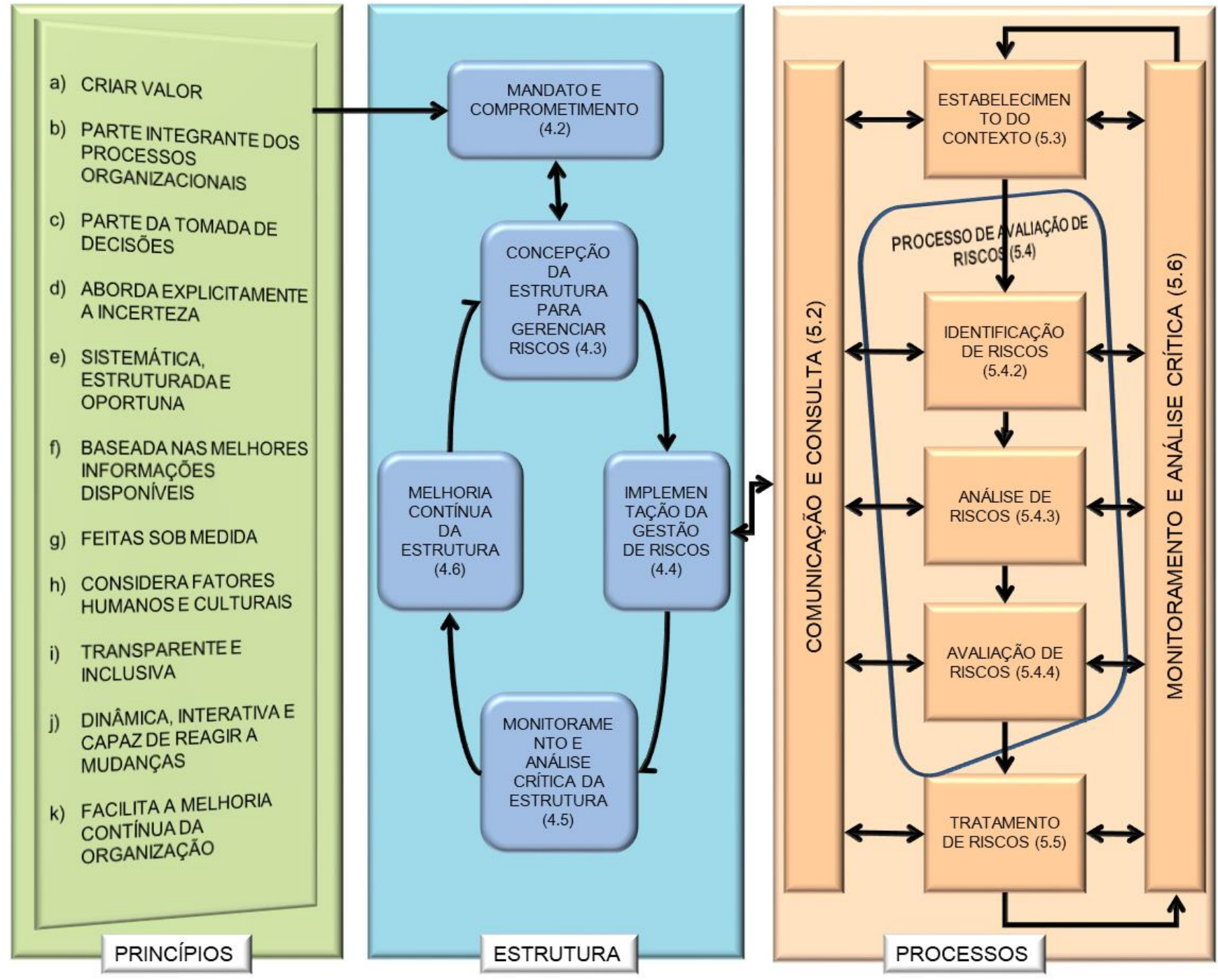

Fonte: ABNT ISO:31.000 (2009)

Conforme o demonstrado na Figura 08 , os Princípios são detalhados e relacionados à criação e proteção de valor, e colocam-se como parte integrante dos princípios organizacionais, não se constituindo, portanto, numa atividade alheia à realidade da empresa. Os princípios são suporte para o estabelecimento da Estrutura, que precisa 
ser eficaz no fornecimento dos fundamentos e arranjos que viabilizarão a correta gestão do risco corporativo.

A estrutura assegura que a informação sobre riscos seja adequadamente reportada e utilizada como base para a tomada de decisões em todos os níveis organizacionais aplicáveis. A estrutura também precisa visar à incorporação da gestão de risco corporativo em todos os Processos da organização, e deve assegurar e alocar os recursos apropriados (adaptado de ABNT ISO:31.000, 2009). Princípios e Estrutura são apresentados como tábuas únicas.

Os Processos, por sua vez, subdividem-se em Comunicação e Consulta, que deve ocorrer durante todas as fases do Processo. Deve abranger as áreas interna e externa, e deve elucidar causas, consequências e medidas tratativas do risco. A correta Comunicação evita julgamentos baseados em opiniões personalistas e não abalizadas, reduzindo os impactos do risco sobre a imagem da companhia; Processo de Avaliação de Risco, que é a identificação das fontes, impactos, eventos, causas e consequências do risco, sua análise (compreensão do risco) e avaliação de severidade, para elencagem e priorização das medidas de tratamento; Monitoramento e Análise Crítica, que são a checagem ou vigilância regulares para riscos frequentes ou que tenham ocorrido isoladamente, com clara definição da responsabilidade dos controladores.

\subsubsection{Abordagem Nohara et al. (2005)}

O Gerenciamento do Risco Corporativo não pode e não deve ser uma atividade estanque, cuja análise se repita somente a intervalos. Deve ser uma atividade incorporada ao cotidiano dos funcionários. Com a mesma intensidade com que as organizações administram produtividade, deve-se também administrar os riscos que circundam o negócio.

O Gerenciamento do Risco Corporativo deve ser encarado como um sistema. Embora composto de várias atividades, no final precisa formar um conjunto de informações que seja composto de identificação, análise, plano de ação, ações efetivas e comunicação dos elementos de risco a toda a organização. Os departamentos não devem analisar seus riscos individualmente, mas em forma de fluxo integrado, considerando atentamente seu permeio por todas as atividades. Nohara et al. (2005) complementam ainda que o gerenciamento de risco corporativo nessa visão integrada deve focalizar 
não somente a mitigação dos riscos, mas suportar também às atividades relacionadas que trazem inovação ao processo.

Reforçando sua visão, Nohara et al. (2005) propõem um modelo de Gerenciamento de Risco Integrado, simplificado e adaptado na Figura 09, cuja aplicação metodológica permite aos empregados e à organização entender melhor a natureza dos riscos e administrá-los sistematicamente.

Figura 09: Modelo de Gerenciamento de Risco Integrado

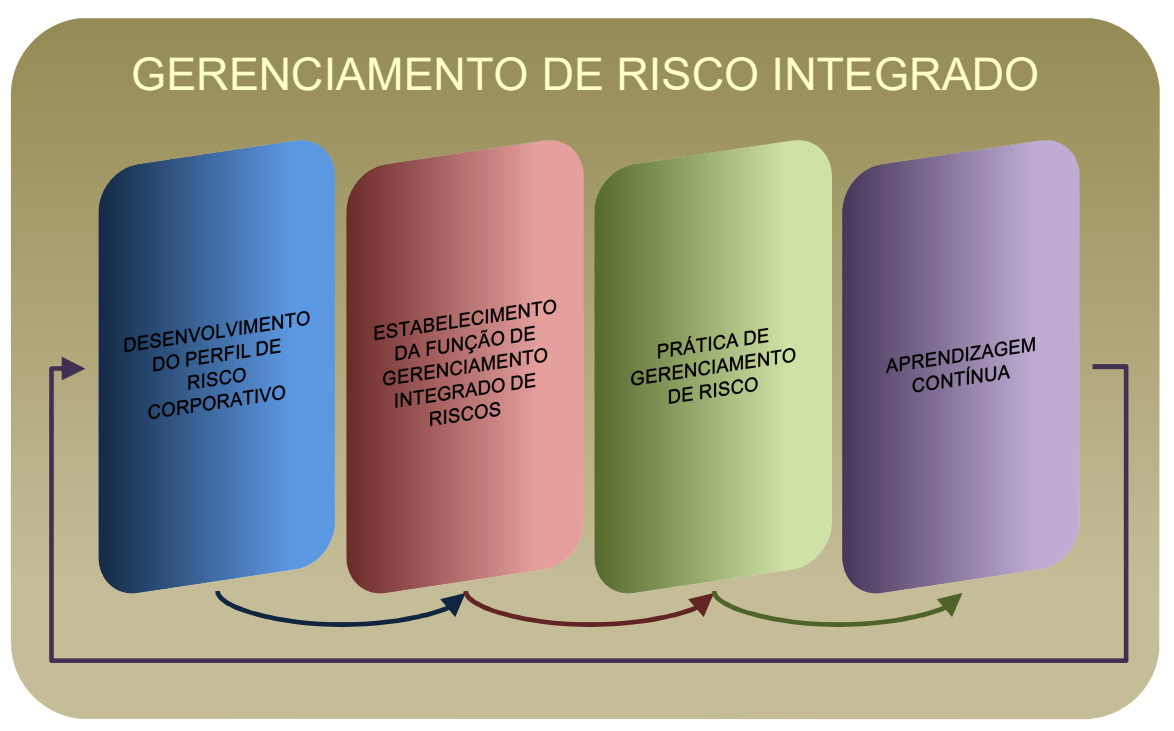

Fonte: adaptado de Nohara et al. (2005)

No modelo, o Desenvolvimento do Perfil de Risco Corporativo examina ameaças e oportunidades no contexto dos objetivos estabelecidos. Os departamentos envolvidos entendem os riscos que serão enfrentados e devem buscar gerenciá-los. Quando ocorre o Estabelecimento da Função de Gerenciamento Integrado de Riscos, o que se espera é o estabelecimento de uma infraestrutura com o claro objetivo de organizar objetivos e estratégias para gerenciar os riscos, alinhando-se com os objetivos e dando ao gerenciamento de riscos a devida prioridade. A Prática do Gerenciamento de Risco deve ser harmonizada aos objetivos organizacionais e requer compromisso contínuo, devendo ser suportada por uma infraestrutura adequada. A Aprendizagem Contínua amarra o modelo, valorizando a experiência adquirida e suportando a melhoria contínua. 


\subsubsection{Comparação das Abordagens COSO (2013) x ABNT ISO (2009) x Nohara et al. (2005) e Justificativa da Adoção de Gerenciamento de Risco Corporativo Proposto para o Caso}

A Figura 10 traz uma comparação entre as Abordagens COSO (2013), ABNT ISO (2009) e Nohara et al. (2005) para o Gerenciamento de Risco Corporativo.

Figura 10: Comparativo entre as Abordagens COSO (2013) x ABNT ISO (2009) x Nohara et al. (2005)

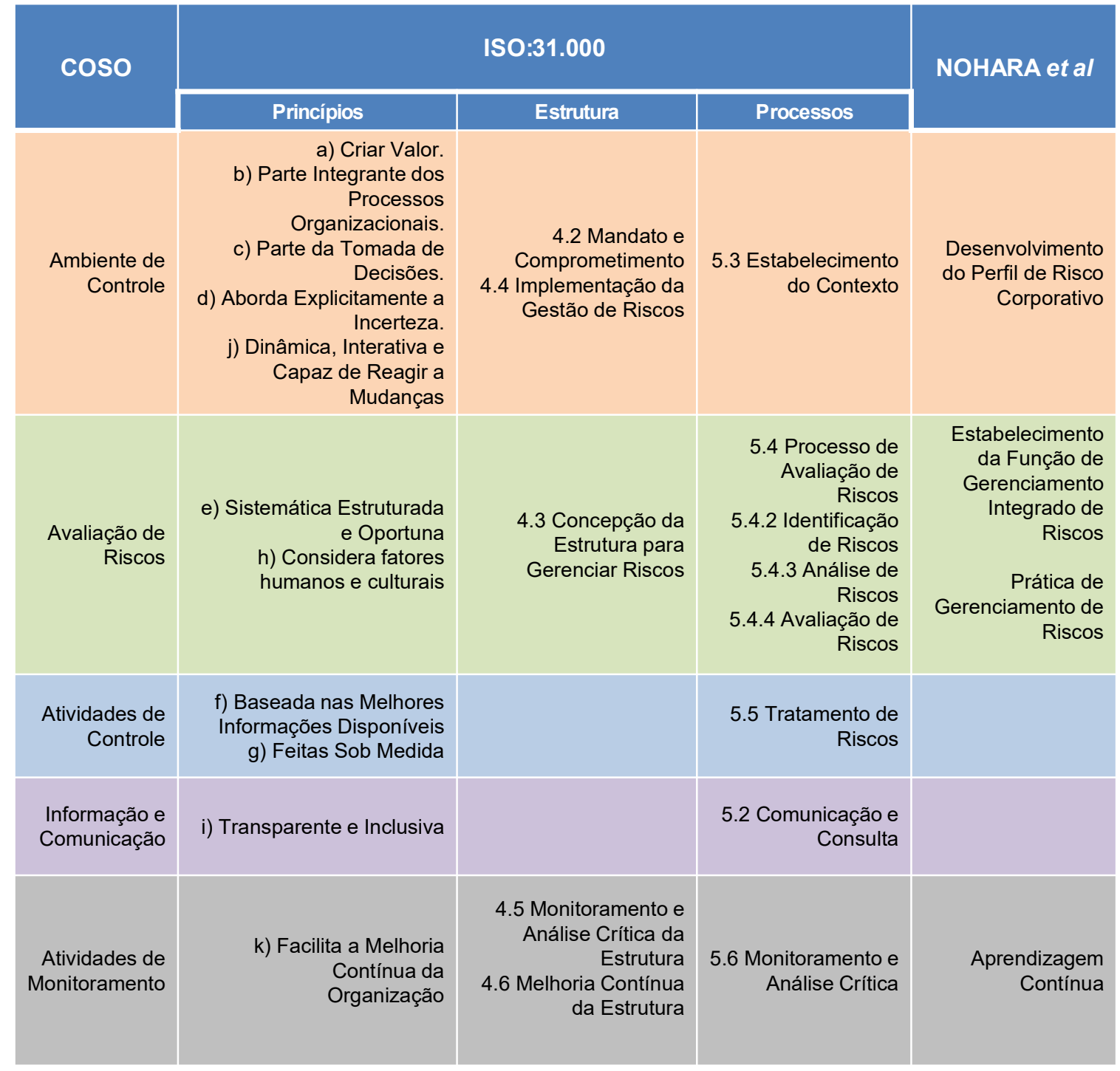

Fonte: autoria própria (2018), com base em COSO (2013), ABNT ISO (2009) e Nohara et al. (2005) A abordagem COSO (2013), não só pelo material exposto nesse trabalho, mas pela própria riqueza de conhecimento disponibilizada, traz uma estrutura bastante completa e, a um tempo, exposta de forma bastante simplificada. Seu componente Ambiente de 
Controle orienta à organização em seu comportamento corporativo, estabelecendo papéis específicos para a Alta Direção e para as outras esferas da Organização.

Comparativamente, a abordagem ABNT ISO (2009) descreve os mesmos componentes através dos Princípios a, b, c, d, j, dos itens da Estrutura 4.2 e 4.4 e do Processo 5.3.

Nohara et al. (2005) aborda as mesmas orientações através de seu Desenvolvimento do Perfil de Risco Corporativo. O componente Avaliação de Riscos orienta à organização a identificar e avaliar riscos e relacioná-los a seus objetivos. A ABNT ISO (2009), nesse quesito, utiliza-se dos Princípios E e H do item de Estrutura 4.3; e dos Processos 5.4; 5.4.2; 5.4.3 e 5.4.4. Nohara et al. (2005), para o mesmo quesito, cita em seu modelo o Estabelecimento da Função do Gerenciamento Integrado de Riscos e a Prática de Gerenciamento de Riscos. O componente Atividades de Controle visa conduzir à organização para especificar seus objetivos, desenvolver seus controles de risco e ainda sedimenta-los em políticas e procedimentos de modo a garantir o padrão desejado em aplicações futuras.

ABNT ISO (2009) aborda o mesmo componente através dos Princípios f, $g$ e do Processo 5.5, e Nohara et al. (2005), ainda que não tenha um item específico em seu modelo, cita a necessidade permeada entre as outras funções. O componente Informação e Comunicação de COSO (2013) busca orientar à organização para obter e/ou gerar informações confiáveis e fundamentá-las e divulgá-las interna e externamente da forma mais adequada. ABNT ISO (2009) aborda a função através do Princípio i e do Processo 5.2, enquanto Nohara et al. (2005) novamente permeia a necessidade entre as outras funções. Por fim, o componente Atividades de Monitoramento conduz a organização a avaliar com frequência seus controles internos e suportar à Alta Direção, quando apropriado, com correções desses controles para tornar mais eficiente o monitoramento dos riscos. A abordagem ABNT ISO (2009) o faz através do Princípio k, dos itens de Estrutura 4.5 e 4.6 e do Processo 5.6, e Nohara et al. (2005) através da função Aprendizagem Contínua de seu modelo.

O autor, portanto, considerou que a ABNT ISO:31.000 (2009) aborda o mesmo tema de forma mais complexa, Nohara et al. (2005) o faz através de agrupamentos que não facilitam a aderência ao caso proposto, enquanto que COSO (2013) o faz de forma 
mais completa, motivando sua escolha como proposta para a organização, sem, obviamente, desmerecer o imenso valor acadêmico e prático de cada uma das outras duas abordagens citadas. Outro ponto a destacar é que, no Brasil, COSO (2007) é referenciado como parâmetro de gerenciamento de risco pela BM\&F Bovespa (2015).

\subsection{Avaliação de Maturidade em Gerenciamento de Risco Corporativo}

Para Cuenca et al. (2013), avaliar a maturidade de uma empresa no gerenciamento de risco corporativo justifica-se, em termos de importância, por ajudar a entender a situação organizacional e por auxiliar a identificar a forma mais adequada de melhorar o sistema.

\subsubsection{Abordagem de Poltronieri (2014)}

Poltronieri (2014) realizou extensa e eficiente revisão da literatura, elaborando um interessante modelo de Avaliação de Maturidade Empresarial em Sistemas de Gestão Integrados $(\mathrm{SGI})$, que após passar por revisões de catedráticos e profissionais de mercado, chegou a uma versão final bastante abrangente e de aplicação relativamente simples, e por isso mesmo, bastante adaptável a vários tipos de realidades organizacionais. 
Figura 11: Sumário do Modelo de Avaliação de Maturidade proposto em Poltronieri (2014)

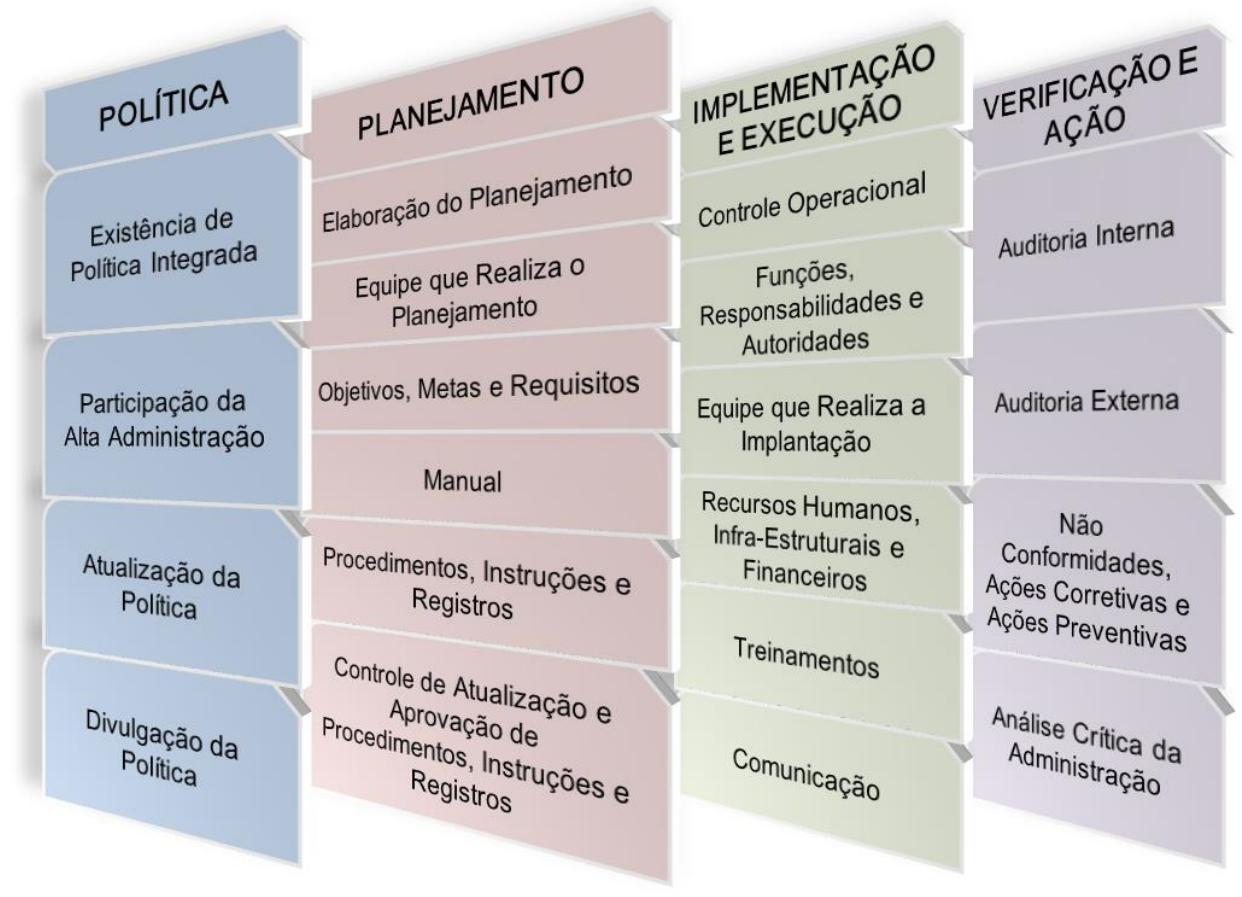

Fonte: adaptado de Poltronieri (2014)

O modelo propõe classificação do nível de maturidade entre 1 e 5 , sendo o nível 1 Imaturo e o nível 5 Maduro, descrevendo, para cada grandeza (Política; Planejamento; Implementação e Execução; Verificação e Ação) o nível de maturidade de forma bastante didática. Para todas as grandezas o objetivo é verificar o nível de integração entre as áreas, o nível de envolvimento da Alta Administração no gerenciamento do risco corporativo e o quanto o sistema é "vivo", ou seja, com que frequência é revisado e revisitado.

A grandeza Política trata do estabelecimento de diretrizes para as diversas funções, é subdividida em 4 partes: Existência de Política Integrada, para avaliar o quanto integrada ou descoordenada é a política de gerenciamento de risco corporativo; Participação da Alta Administração, para avaliar se o sistema é uma inciativa corporativa (Top-Down) ou de departamentos em específico (Bottom-Up), o que sempre pode tornar o gerenciamento de risco corporativo menos efetivo; Atualização da Política, que visa avaliar o quão renovada e "viva" a política é; e Divulgação da Política, que mede o quão entremeada é a gestão de risco corporativo dentro da companhia. $A$ grandeza Planejamento trata da criação das normas, e é mais detalhada, dividida em 6 
partes. A Elaboração do Planejamento mede o quão integrado é o planejamento do gerenciamento de risco corporativo; a Equipe que Realiza o Planejamento mensura o número de pessoas envolvidas no planejamento e o quanto seu trabalho é integrado; os Objetivos, Metas e Requisitos medem o quanto o gerenciamento de risco corporativo é alinhado às metas estratégicas da empresa; o Manual mede a qualidade e a integração do registro escrito do planejamento; Procedimentos, Instruções e Registros mede a clareza das diretrizes e seu enraizamento na organização; e o Controle de Atualização e Aprovação de Procedimentos, Instruções e Registros mede a governança do material gerado. A grandeza Implementação e Execução trata da implementação das normas nos diversos ambientes, e também é dividida em 6 partes. O Controle Operacional mede assertividade em se determinar a importância de cada atividade no gerenciamento de risco corporativo, a correta medição dessas atividades através de indicadores e a frequência das revisões (atualizações) das atividades; Funções, Responsabilidades e Autoridades indica o nível de maturidade do estabelecimento das funções na atividade de gerenciamento de risco corporativo e seu alinhamento com o planejamento estratégico da companhia; Equipe que Realiza a Implantação mensura unidade da equipe e seu desempenho frente aos objetivos da atividade; Recursos Humanos, InfraEstruturais e Parceiros mensura a maturidade em disponibilidade de recursos e seu desempenho no gerenciamento de risco corporativo; Treinamentos mensura a maturidade em que as pessoas são envolvidas e conscientizadas sobre a atividade; e Comunicação mede o permeio da divulgação do andamento das atividades pela companhia. Por fim, a grandeza Verificação/Ação confere ao processo a característica cíclica, mantendo-o dinâmico e atualizado. A Auditoria Interna mede a qualidade dos indicadores, a conformidade da atividade e a evolução do sistema; a Auditoria Externa tem a mesma função, porém é executada por um órgão certificado e certificador; as Não-Conformidades, Ações Corretivas e Preventivas são mensuradas conforme o nível de maturidade em seu tratamento; e a Análise Crítica da Administração fecha o ciclo medindo o processo como um todo e o comprometimento da Alta Administração com sua execução e manutenção.

Poltronieri (2014) propõe a avaliação por Nível de Maturidade. Depois dessa avaliação deve seguir-se um plano de ação para atacar os pontos identificados com menor nível 
de maturidade. Complementarmente a Poltronieri (2014), o autor propõe que os planos de ação sejam priorizados, uma vez que num primeiro ataque pode ser inviável tratar de todos ao mesmo tempo. O autor recomenda a leitura do material referenciado, que detalha grandeza por grandeza e ilustra a aplicação com um exemplo bastante didático. Através da aplicação do modelo chega-se ao nível de maturidade da organização no gerenciamento de risco corporativo, e as grandezas e suas divisões que obtiverem menores níveis de maturidade devem receber tratamento prioritário.

\subsubsection{Abordagem de Oliva (2016)}

Considerando que não se pode falar de avaliação de maturidade empresarial sem que se fale da avaliação de risco propriamente dita, em sua fundamentação o artigo utilizado como base propõe um modelo conceitual demonstrando a exposição da companhia a riscos no ambiente de valor e no ambiente de negócios nos quais se insere.

Figura 12: Riscos Empresariais no Ambiente de Valor - Tradução Livre do Autor.

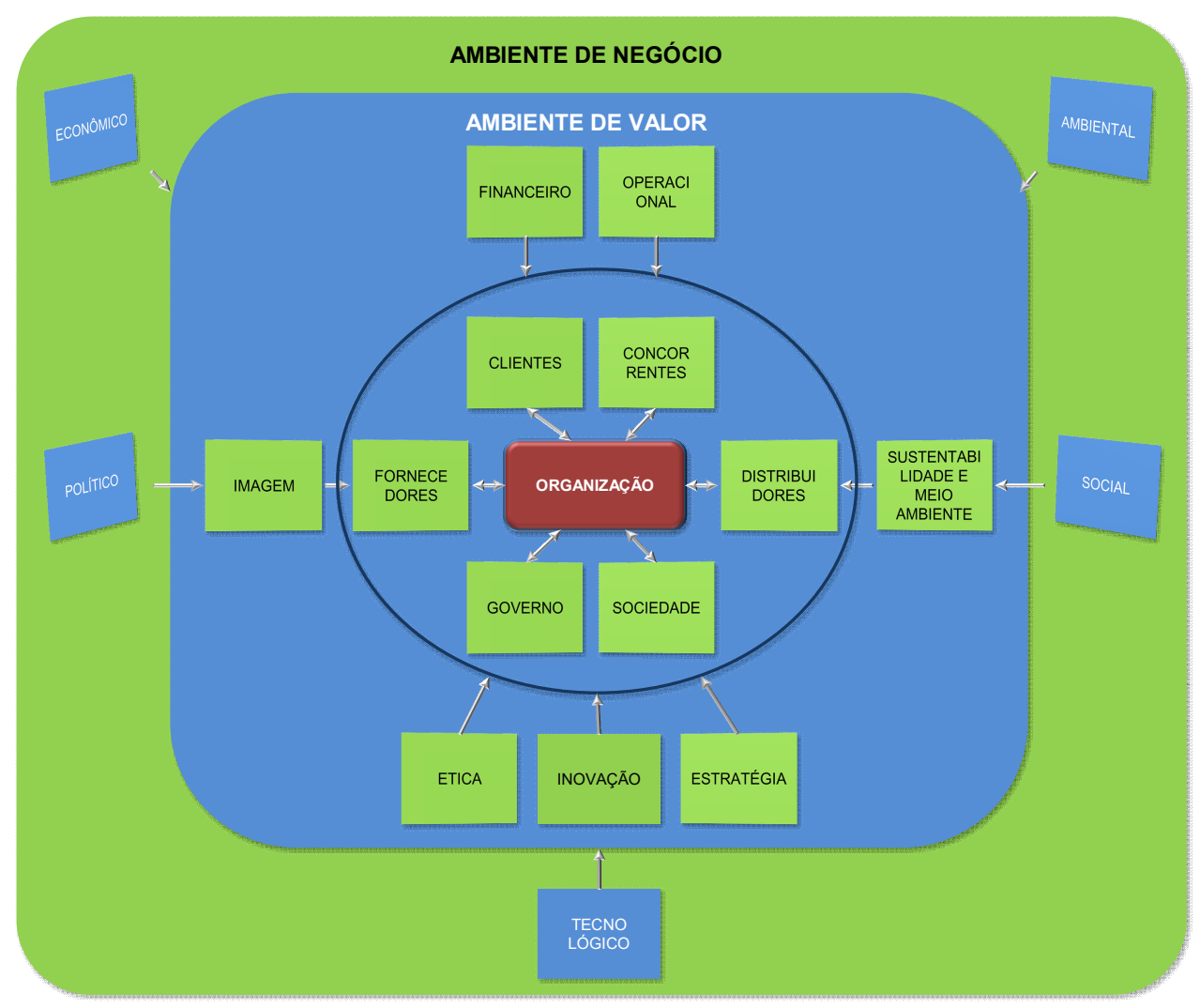

Figura Original em Anexo 04 - Fonte: Oliva (2016) 
O modelo conceitual da Figura 12 foi desenvolvido por Oliva (2016). Descrevendo-o mais detalhadamente, Oliva (2016) afirma que o Ambiente de Valor é formado pelos principais agentes geradores de valor para a Organização. Nesse ambiente, as relações são estabelecidas considerando que cada parte será contemplada com o melhor que a outra parte poderá ofertar. Os níveis de governança que maximizem os ganhos mútuos devem ser buscados. Os agentes do Ambiente de Valor são os mesmos do Ambiente de Negócio. Entretanto, para serem assim considerados, devem manter ou criar valor para a organização. Nesse ambiente os principais agentes são: Clientes, Fornecedores, Distribuidores, Sociedade, Governo e Concorrentes. Do ponto de vista de análise de risco, os riscos empresariais advêm das relações internas da organização e das relações da organização com o Ambiente de Negócio. A análise de risco empresarial que desconsidere essa conexão, por encarar os fatos isoladamente, pode ser enganosa. Oliva (2016) coloca como exemplo situacional que uma empresa pode ser muito atenta a riscos relacionados à ética de mercado em seu ambiente interno, mas um fornecedor estratégico pode estar utilizando-se de práticas trabalhistas ilegais. Advoga, assim, que a avaliação de risco precisa ser sistêmica, considerando a organização e suas relações de valor contra um ambiente de negócio de ameaças e oportunidades. No tocante ao Ambiente de Negócio, os principais riscos têm origem em eventos Econômicos, Políticos, Sociais, Tecnológicos e Ambientais. Já no Ambiente de Valor, onde a Organização mutuamente influencia e sofre influência, os principais riscos são o Financeiro, Operacional, de Imagem, Meio Ambiente e Sustentabilidade, Ética, Inovação e de Estratégia.

No tocante à Avaliação de Maturidade Empresarial, há uma compilação de dados de questionários administrados a 243 gerentes escolhidos entre as 1.000 maiores empresas do Brasil conforme o ranking da revista Exame (2011). No artigo, Oliva (2016) registra que, de posse das informações, realizou-se análise de fatores e redução dos dados, visando identificar os fatores importantes para a análise e explicação da questão da avaliação de maturidade das empresas em gerenciamento de risco corporativo. $\mathrm{Na}$ sequência buscou-se um agrupamento de dados por similaridade (clusters), para identificar, por grupos, as diferentes abordagens para o gerenciamento de risco corporativo. Com essa caracterização desenvolveu-se uma logística de análises, 
permitindo identificar que variáveis são importantes para que se classifique em quais dos clusters de maturidade a companhia avaliada se encaixa.

Fundamentado na metodologia de Hair et al. (1998), chega à lista dos riscos mais relevantes no ambiente de valor, quais sejam: Organização, Clientes, Fornecedores, Competidores, Distribuidores, Governo e Sociedade. No desenvolvimento desse estudo, foi possível aos gestores classificar os riscos em quatro grupos: 1) Organização, 2) Tecnicidade, 3) Transparência e 4) Envolvimento. O modelo de avaliação de maturidade proposto identifica qual o nível alcançado pela empresa em cada um dos grupos, dividindo os resultados possíveis em 5 níveis, a saber: C1 Insuficiente; C2 - Contingencial; C3 - Estruturado; C4 - Participativo; C5 - Sistêmico. $\mathrm{Na}$ aplicação do modelo deve se identificar cada risco, listado dentro de cada cluster, de acordo com a classificação de C1 a C5 e priorizar o tratamento com base nos resultados obtidos. Em cada nível, os clusters de $\mathrm{C} 1$ a $\mathrm{C} 5$ são detalhados, possibilitando fundamentar melhor a análise de uma determinada organização quanto ao seu nível de maturidade empresarial, conforme detalhado na Figura 13. 
Figura 13: Nível de Maturidade no Gerenciamento de Risco Empresarial

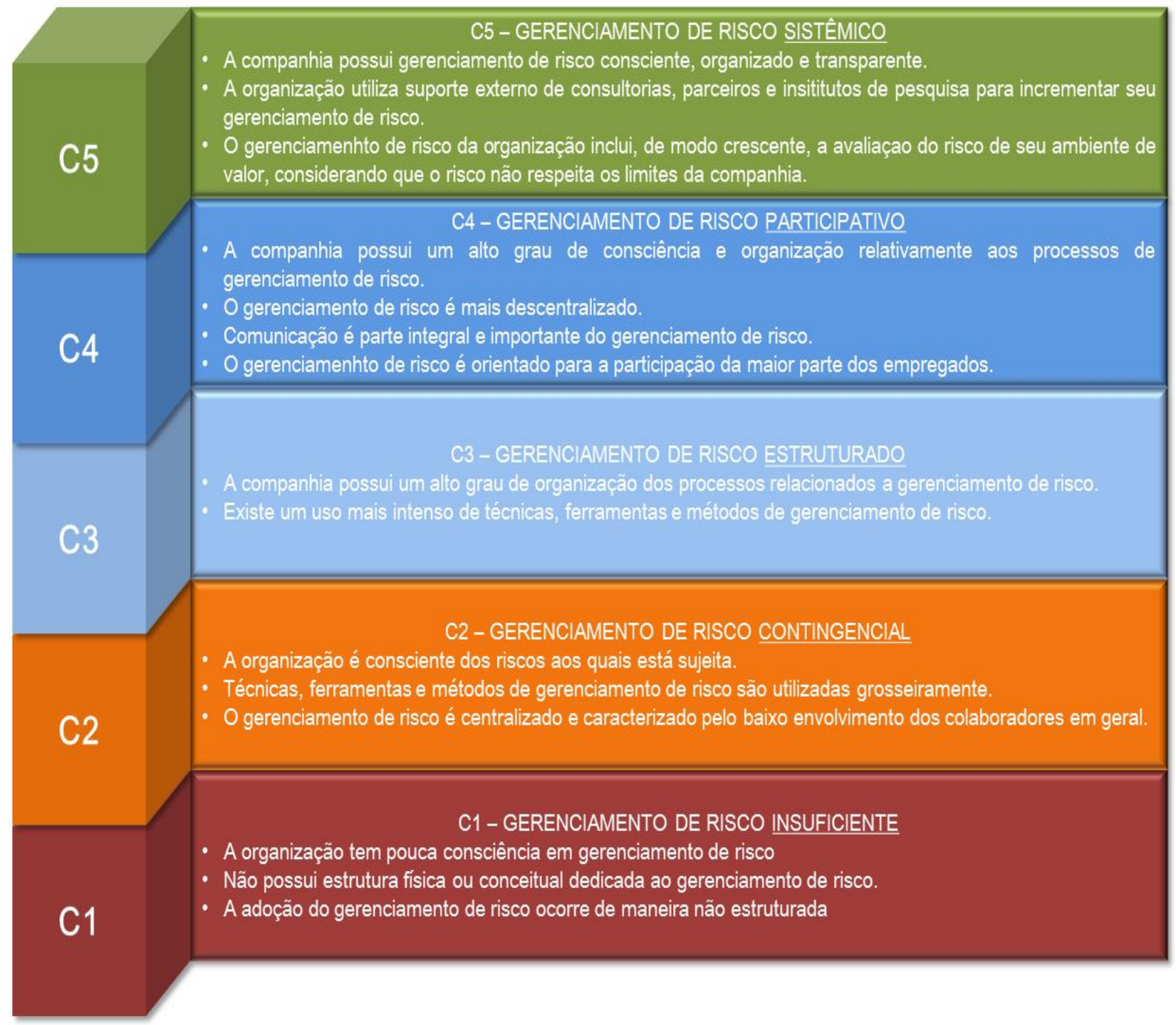

Fonte: Adaptado de Oliva (2016)

A organização deve ser avaliada quanto à estrutura estabelecida para gerenciamento de risco corporativo. A Figura 13 estabelece que nos casos em que a organização tem baixa consciência da importância da atividade, não possui estrutura física nem conceitual dedicada e gerencia seu risco corporativo de forma pouco estruturada, deve ser encaixada no cluster C1 - Gerenciamento de Risco Insuficiente. Quando a organização iniciou a utilização de técnicas, ferramentas e métodos para suporte da atividade e centralizou o gerenciamento de risco corporativo, mas ainda conta com baixo envolvimento dos colaboradores, deve ser avaliada como C2 - Gerenciamento de 
Risco Contingencial. Quando a organização já organizou seus processos de risco em alto grau, e em complemento utiliza intensamente as técnicas, ferramentas e métodos de suporte, deve ser avaliada como C3 - Gerenciamento de Risco Estruturado. Nos casos em que a organização já possui um alto grau de organização da atividade, assim como está altamente ciente de sua importância; já teve condições de descentralizar o gerenciamento de risco corporativo, permitindo sua permeabilidade pela estrutura; já incorporou a comunicação como parte integrante do processo e consegue abranger a maior parte dos colaboradores na atividade, pode ser posicionada no cluster de maturidade C4 - Gerenciamento de Risco Participativo. As organizações experientes em gerenciar seu risco corporativo, primando pela consciência, organização e transparência, integrando suporte externo como alavancagem de melhoria e transcendendo os limites da companhia quando avalia seus riscos deve ser avaliada como C5 - Gerenciamento de Risco Sistêmico.

\subsubsection{Abordagem de Hillson (1997)}

Hillson (1997) direciona seu artigo para organizações que desejam implementar formalmente um método de gerenciamento de risco corporativo ou desejam melhorar o que já possuem. Para tal, precisam de uma estrutura para usar como benchmark. $\mathrm{O}$ resultado é estruturado em níveis de maturidade, situando a organização em níveis crescentes de assertividade dentro do gerenciamento de risco corporativo adotado. $\mathrm{O}$ artigo descreve um modelo de maturidade no gerenciamento de risco corporativo de 4 níveis, que permitem à organização não apenas avaliar-se e posicionar-se em um dos níveis, mas identificar metas de melhoria e produzir planos de ação para desenvolver ou aumentar sua capacidade de gerir riscos. Pontua que a organização deve ser capaz de avaliar sua maturidade atual e capacidade no gerenciamento de risco corporativo, utilizando uma metodologia estruturada para avaliar objetivamente níveis atuais e ser auxiliada pela metodologia para determinar o nível de progresso desejado na direção do aumento de sua maturidade.

A classificação determina os 4 níveis como: 1) Ingênuo (Naive); 2) Novato (Novice); 3) Normatizado (Normalised) e 4) Natural (Natural). A análise utiliza 4 grupos de risco: Cultura, Processos, Experiência e Aplicação. O método indica, então, as atitudes que 
permitirão à empresa migrar seu grau de Naive para Novice; Novice para Normalised e Normalised para Natural.

Os níveis são assim organizados:

- $\quad$ Nível 1 - NAIVE (Ingênuo) - A organização não tem ciência da necessidade de um modelo de gerenciamento de risco corporativo. Não tem estrutura para lidar com incertezas. O processo de administração é repetitivo e reativo. Não aprende com o passado nem se prepara para as incertezas futuras.

- $\quad$ Nível 2 - NOVICE (Novato) - A organização está ciente dos potenciais benefícios de um processo de gerenciamento de risco corporativo, mas não tem processo formal implementado nem está usufruindo de todos os benefícios. A organização fez ou faz tentativas com aplicações de gerenciamento de risco corporativo, através de alguns colaboradores, mas não tem um processo estruturado.

- $\quad$ Nível 3 - NORMALISED (Normalizada ou Normatizada) - A organização possui processo implementado nos processos de rotina e nos principais ou em todos os projetos. O gerenciamento de risco corporativo é formalizado e divulgado, os benefícios são conhecidos em todos os níveis da organização, embora não sejam plenamente usufruídos em alguns casos.

- $\quad$ Nível 4 - NATURAL - A organização possui uma cultura de sensibilização ao risco, estendendo o gerenciamento de risco corporativo a todos os processos de negócios. As informações sobre riscos são usadas ativamente para melhorar os processos de negócios e ganhar vantagem competitiva. Os processos de risco são utilizados para gerenciar oportunidades e prevenir potenciais impactos negativos.

No Anexo 03 verifica-se que atributos estão tipicamente presentes em cada nível de maturidade. A tabela permite que a organização se auto avalie contra critérios claros, e pode planejar-se para migrar para níveis mais altos a partir da avaliação inicial. 
A organização pode planejar-se para mais atos níveis de maturidade através de planejamento estratégico e através de práticas mais efetivas de gerenciamento de risco corporativo. A organização também pode avaliar-se contra concorrentes ou pares, visando amealhar vantagem competitiva. Hillson (1997) pontua que é importante que a empresa se auto avalie e, posteriormente, estabeleça a meta de aperfeiçoamento. Entretanto, aconselha que a empresa estabeleça metas coerentes. Migrar, por exemplo, do Nível 1 para o 3 pode trazer muitas dificuldades, e talvez seja producente migrar primeiro de Nível 1 para 2 e, posteriormente, para 3. Uma vez alcançado e consolidado o Nível 3 em sua rotina, será saudável então almejar o Nível 4 e alcançar plenamente os benefícios do gerenciamento de risco corporativo. Hillson (1997) prossegue com os passos para migração de nível para nível, a seguir em resumo adaptado pelo autor.

- $\quad$ Nível 1 para 2 - Naive para Novice

As ações incluem a contratação de consultoria especializada, seleção de pessoal interno para o time experimental, estabelecer o patrocinador da iniciativa, iniciar programa de comunicação interno abrangente, estabelecer planejamento do projeto, escolher os processos que serão implementados, construir métricas, prospectar métodos e iniciar a confecção dos procedimentos e templates.

- $\quad$ Nível 2 para 3 - Novice para Normalised

Fortalecer o time interno com autonomia e treinamentos. Utilizar a consultoria para estender o gerenciamento de risco corporativo aos principais departamentos da empresa, alocar recursos e estabelecer orçamento para a atividade, divulgar o sucesso dos projetos mais bem-sucedidos para todas as áreas da empresa, consolidar os procedimentos e formalizar o processo de gerenciamento de risco corporativo, selecionar métodos e estabelecer controles rotineiros. 
- $\quad$ Nível 3 para 4 - Normalised para Natural

Assegurar que a organização aprenda com a experiência e revisar o processo regularmente, garantindo que permaneça efetivo. Assegurar recursos para melhoria em treinamentos, novos métodos, etc. Garantir que todos os processos da empresa estejam cobertos pelo gerenciamento de risco corporativo, desenvolvendo a cultura de Total Risk Management. Assegurar que a rotina de avaliação de risco faça parte dos processos de tomada de decisão. Manter o time interno motivado, através de treinamentos de reciclagem, contatos com a consultoria especializada, divulgando as métricas e introduzindo mudanças.

- $\quad$ Mantendo o Nível 4 - Natural

Assegurar o comprometimento contínuo da alta direção da organização. Manter a atividade de gerenciamento dentro dos padrões de qualidade estabelecidos, através de auditagens e revisões periódicas. Usufruir das vantagens competitivas que resultam de um gerenciamento de risco corporativo proativo, manejando riscos e oportunidades. Buscar pioneirismo de mercado na aplicação do gerenciamento de risco corporativo. Investir regularmente em aperfeiçoamento do processo e envolver clientes e fornecedores no seu gerenciamento de risco corporativo.

\subsubsection{Comparação das Abordagens Poltronieri (2014) x Oliva (2016) x Hillson (1997) e Justificativa da Adoção de Modelo de Avaliação de Maturidade Proposto para o Caso}

Seguindo a mesma linha utilizada na avaliação de um modelo de gerenciamento de risco corporativo a ser recomendado para a empresa analisada, o autor também realizou uma análise dos modelos de avaliação de maturidade empresarial estudados. No tocante aos grupos de risco, os três modelos trazem abordagens diferentes, como se verifica na Figura 14. 
Figura 14: Demonstrativo de Agrupamentos de Risco - Poltronieri (2014) x Oliva (2016) x Hillson (1997)

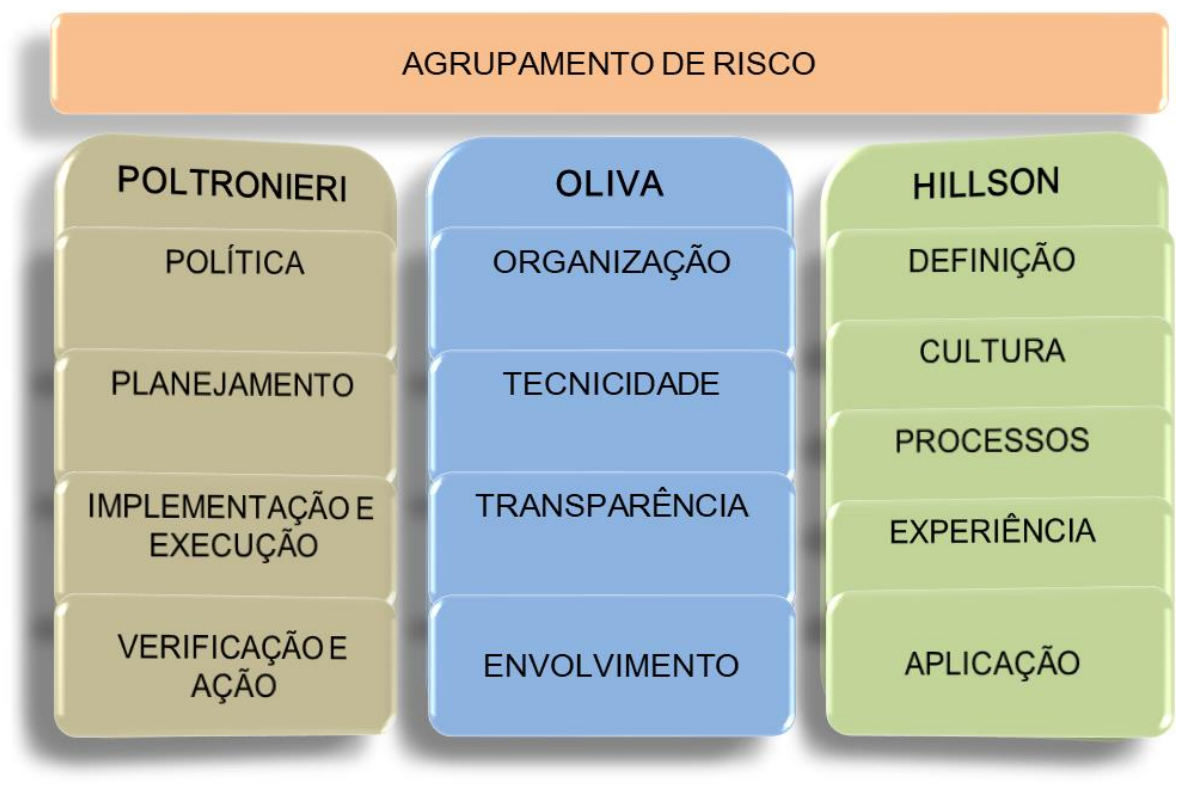

Fonte: autoria própria

Poltronieri (2014) agrupa seus riscos em Política, que engloba direcionamentos organizacionais, engajamento da Alta Direção, procedimentos, missão, valores, etc.; Planejamento, que engloba a fase de integração e levantamentos de dados; a Implementação e Execução, que é a definição do conteúdo do gerenciamento e a operação do modelo; e Verificação e Ação, que garante a ciclicidade do modelo e ações corretivas sobre eventuais problemas detectados na operação do modelo.

Oliva (2016) tem um agrupamento diferente, com o fator Organização englobando o planejamento, implementação e o controle do processo; o fator Tecnicidade englobando o suporte técnico necessário à implementação do gerenciamento de risco corporativo; o fator Transparência englobando o gerenciamento participativo, com envolvimento da Alta Direção, e a comunicação efetiva de todas as etapas do processo, e o fator Envolvimento englobando o suporte externo necessário ao processo e a análise do Ambiente de Valor.

Hillson (1997) tem outra abordagem, e no grupo Definição engloba o estabelecimento de um processo de gerenciamento de risco corporativo, com proatividade, suporte de informações e senso de oportunidade na gestão do risco (conceito chamado de positive risk). No grupo Cultura engloba o envolvimento da Alta Direção, liderança pelo exemplo 
e proatividade no gerenciamento de risco corporativo encorajada e recompensada. No grupo Processos engloba processos baseados nos riscos dos negócios, o envolvimento de toda a organização, e não somente de alguns departamentos, no gerenciamento de risco corporativo, revisão e aprimoramento constantes dos processos e avaliação rotineira através de métricas. No grupo Experiência engloba as recomendações de que todo o staff tenha conhecimentos básicos de gerenciamento de risco corporativo, gestão do conhecimento acumulado como meio de aprendizado e constante aprimoramento através de treinamentos externos. Por fim, no grupo Aplicação recomenda que o gerenciamento de risco corporativo seja natural à empresa, aplicado a todas as atividades, com decisões e ações baseadas em informações e que os métodos e procedimentos estejam no estado da arte.

A Figura 15 compara as escalas criadas por cada um dos autores para avaliar a maturidade da organização em cada um dos grupos de risco criados. Como se pode verificar, as escalas guardam maior semelhança que os agrupamentos.

Figura 15: Comparação de Escalas para Avaliação do Grau de Maturidade - Poltronieri (2014) x Oliva(2016) x Hillson (1997)

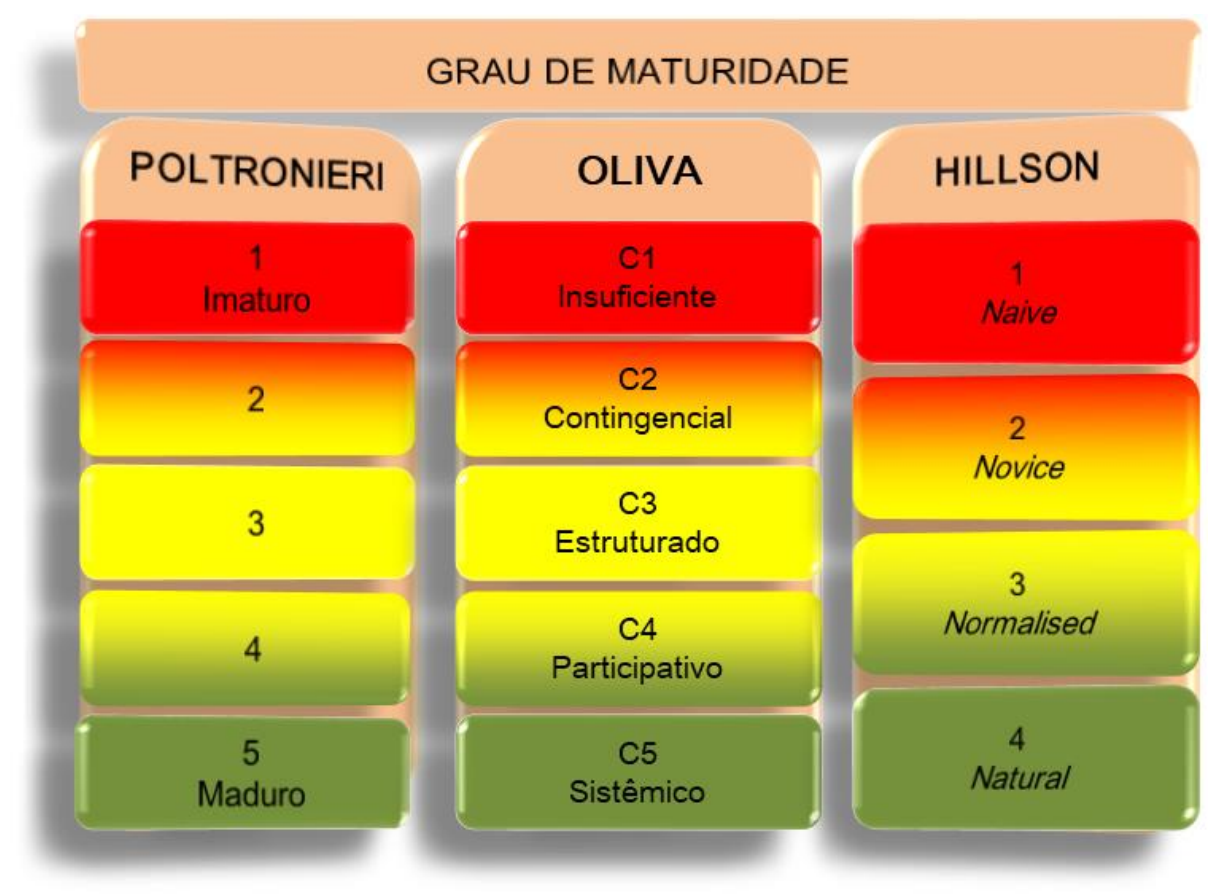

Fonte: autoria própria 
Poltronieri (2014) propõe uma escala de 1 a 5, indo de 1-Imaturo a 5-Maduro.

Oliva (2016) propõe uma escala de 5 clusters (C1 a C5), na qual o nível C1-Insuficiente posiciona o modelo numa situação onde não há estrutura física ou conceitual de gerenciamento de risco corporativo, e essa atividade ocorre de maneira não estruturada. O nível C2 - Contingencial posiciona o modelo como ciente dos riscos a que está submetido, utilizando ferramentas e métodos de forma rudimentar e com envolvimento restrito a algumas áreas da organização. O nível C3 - Estruturado o posiciona com alto grau de organização de processos e um uso intenso de técnicas, ferramentas e métodos. O nível C4 - Participativo indica um modelo com alto nível de consciência e organização e um gerenciamento de risco corporativo permeado pela companhia, além de apontar a comunicação como parte integral do processo. Ainda, o gerenciamento de risco corporativo é orientado para participação da maior parte dos funcionários. O último Nível, C5 - Sistêmico, classifica o modelo como organizado, consciente e transparente, com a organização utilizando-se de expertise externa para a evolução do gerenciamento de risco corporativo, gerenciando inclusive os riscos de seu ambiente de valor, extrapolando sua própria cadeia, e servindo como benchmark para o mercado.

Hillson (1997) propõe uma escala de 1 a 4, na qual o nível 1 - Naive (Ingênuo) indica que a organização não está ciente da necessidade de um modelo de gerenciamento, e não tem a atividade estruturada para lidar com incertezas. O processo de gerenciamento é repetitivo e reativo, e não possui gestão do conhecimento para aproveitamento das lições aprendidas em ocasiões futuras. O nível 2 - Novice (Novato) indica a organização que está iniciando a estruturação do gerenciamento de risco corporativo, ainda com um pequeno número de envolvidos, mas ainda sem processos formais em uso, e sem, portanto, colher os benefícios advindos de um processo bem estruturado. O nível 3 - Normalised (Normatizado) indica que a organização transformou o gerenciamento de risco corporativo em rotina estruturada, aplicando-o na maior parte de suas atividades. Processos gerais estão formalizados e bem distribuídos pela organização, e os benefícios são conhecidos, mas não amealhados em todas as situações onde isso seria possível. O último nível, 4 - Natural, posiciona a organização como portadora de cultura de alta consciência do risco, com uma atitude proativa no 
gerenciamento de risco corporativo em todos os seus negócios. As informações relativas a risco são utilizadas para incremento dos processos de negócio e no ganho de vantagem competitiva. Os processos de gerenciamento de risco corporativo são utilizados para administrar oportunidades advindas do risco e, também, impactos negativos em potencial.

O autor, para o modelo de Avaliação de Maturidade Empresarial, considerou que, no tocante a agrupamento dos riscos, as 3 abordagens trazem considerações equivalentes, mas a abordagem de Oliva (2016) aproxima-se, em definição, aos aspectos de risco considerados hoje relevantes pela AkzoNobel. No tocante às escalas propostas, encontrou novamente maior aderência ao tipo de negócio praticado pela AkzoNobel na abordagem de Oliva (2016), pois o detalhamento proposto, apesar de se originar numa abordagem genérica, traz um detalhamento adequado a uma organização industrial. Complementarmente, Oliva (2014), em seu artigo Knowledge Management Barriers, Practices and Maturity Model, tem uma abordagem contemporânea à Avaliação de Maturidade Empresarial através de outros estudos, não só relacionando-a ao Gerenciamento de Risco Corporativo como também à gestão do conhecimento, o que permitiu ao autor uma visão mais abrangente sobre as aplicações do modelo proposto, com possíveis variações e adaptações. Será essa, portanto, a abordagem indicada para adoção pela organização. 


\section{CONTEXTUALIZAÇÃO}

\subsection{A empresa estudada: a AkzoNobel no Brasil}

Figura 16: Estrutura Comercial da AkzoNobel no Brasil

\section{AKZONOBEL}

\section{DIVISÕES DE NEGÓCIOS}
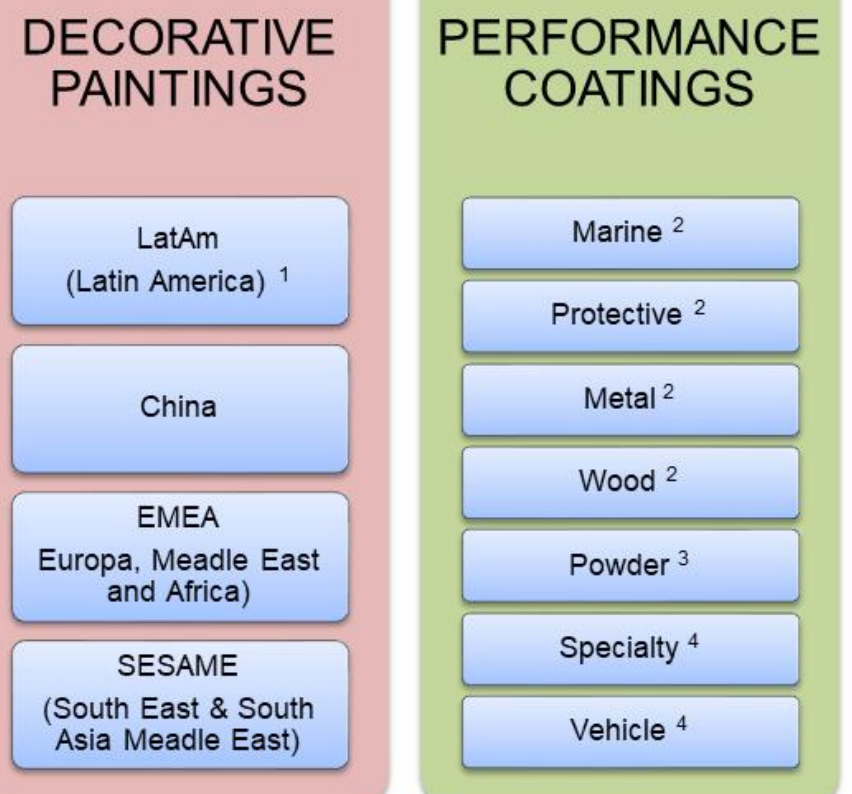

SPECIALTY CHEMICALS

Polymer Chemistry ${ }^{5}$

Surface Chemistry ${ }^{5}$

Pulp \& Performance Chemicals 6

Ethylene and Sulfur Derivatives

Industrial Chemicals 


\section{PLANTASNO BRASIL}
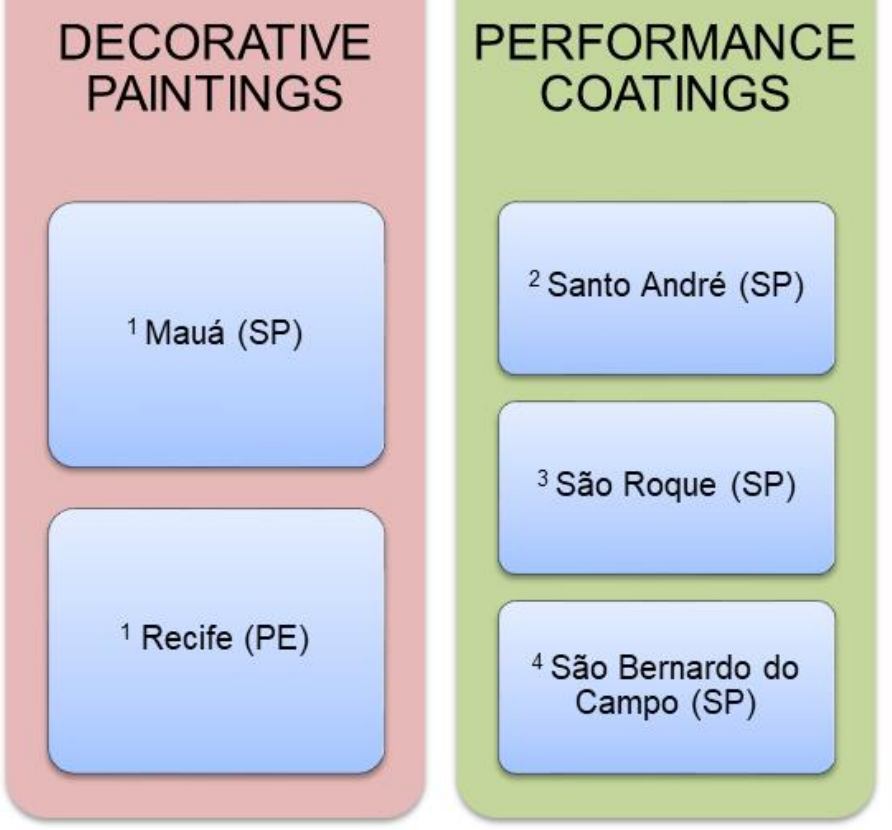
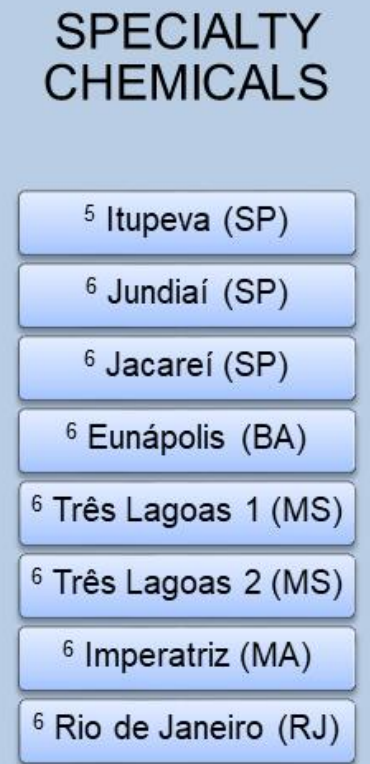

Fonte: adaptada do segmento do site AkzoNobel - How We Are Organized (2016)

A AkzoNobel é uma multinacional holandesa que atua na produção de tintas, químicos e outros derivados desde 1646. É a maior fabricante de tintas do mundo, e costumeiramente cresce através de aquisições.

Está presente em mais de 80 países, e está no Brasil desde os anos 1960.

Divide-se atualmente em três segmentos de negócios, verificados na Figura 16: Decorative Paintings (Tintas Imobiliárias), Performance Coatings (Tintas de cobertura específica e efeito) e Specialty Chemicals (Especialides Químicas).

Decorative Paintings divide-se em áreas geográficas.

Performance Coatings divide-se por unidades de negócios, de acordo com suas especialidades. Possui fábrica em Santo André (SP), para tintas dos segmentos Metal, Wood, Marine e Protective; São Roque (SP) para o segmento de Powder e São Bernardo do Campo (SP) para tintas dos segmentos de Specialty e Vehicles.

Specialty Chemicals é o braço químico do grupo. Possui fábricas em Itupeva (SP), para Polymer Chemistry e Surface Chemistry; Rio de Janeiro (RJ) para Sílicas; Jundiaí (SP), para Pulp \& Performance Chemicals; Jacareí (SP), Eunápolis (BA), Imperatriz (MA) e 2 sites em Três Lagoas (MS), para Pulp \& Performance Chemicals no conceito de Ilhas 
Químicas. As linhas de Ethylene \& Sulfur Derivatives e Industrial Chemicals não possuem plantas locais e são atendidas através de importações intercompanhia.

Nosso segmento de recorte da área de Celulose, Pulp \& Performance Chemicals, produz o branqueador da fibra de celulose e uma esfera expansível para aplicações em solas de sapatos, explosivos, tintas e outras aplicações. O branqueador é fornecido por via granel rodoviária ou diretamente no processo do cliente, que é um fabricante de fibra de celulose. A esfera é produzida na Suécia, expandida em Jundiaí e fornecida em diversas embalagens para diversos segmentos. Importante salientar que o foco do trabalho está no branqueador da fibra de celulose, que responde por mais de $95 \%$ do volume e do faturamento na região.

\subsection{Cadeia de Valor da Indústria de Celulose}

O setor de Celulose tem características peculiares de negócio, começando pelo manejo de recursos naturais e finalizando pelas muitas utilizações do produto final no mercado local e internacional. A regulação legal brasileira é bastante rígida em relação às permissões para as atividades ligadas ao plantio de eucalipto e manejo de áreas verdes, principalmente de grande porte. Outros setores com essa dependência também consideram a matéria-prima como fator de risco, seja considerando aspectos regulatórios ou sua própria disponibilidade, sujeita a fatores naturais. Ainda, há o relevante aspecto das relações com a sociedade, abordado em estudos sobre outros setores econômicos, como afirma o artigo Risks and strategies in a Brazilian innovation - flexfuel technology, sobre a introdução da tecnologia de veículos flex no Brasil: “... e a pressão da sociedade encorajando o uso de combustíveis menos poluentes, a busca por fontes de energia limpa tornou-se uma constante na economia moderna." (Oliva et al., 2014, p. 916).

As florestas de eucalipto, que são a matéria-prima da fabricação, são $100 \%$ reflorestadas, mesmo considerando suas gigantescas extensões. O manejo do eucalipto no Brasil tem imensas vantagens competitivas sobre qualquer outro país, pois alia clima, manejo sustentável e pesquisas de transgênicos. Como resultado, o mesmo eucalipto que leva de 20 a 30 anos para crescer e ser colhido em outros países, no Brasil leva 7 anos e, manipulado geneticamente, 5,5 anos (Paper Mart, 2015.). 
A AkzoNobel atua no processo do branqueamento da fibra da celulose, na etapa localizada na Figura 17, abaixo:

Figura 17: Cadeia de Valor da Indústria de Celulose

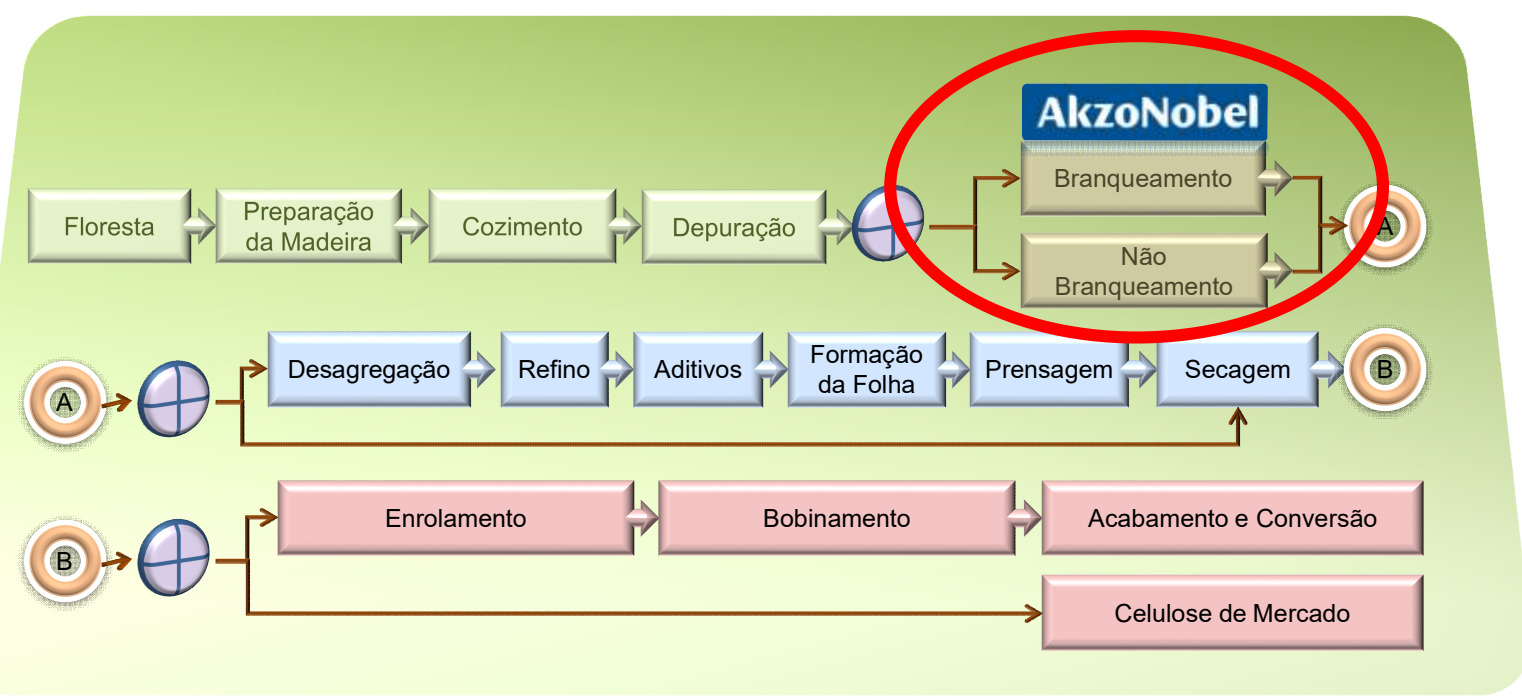

Fonte: adaptado de Silva e Kopittke (2002)

A fibra de celulose sai do processo com uma cor naturalmente parda, chamada de kraft, com tons variando do bege ao marrom. O mercado final demanda fibras brancas para a maior parte das aplicações, especialmente naquelas destinadas ao consumo humano (papel higiênico, fraldas, guardanapos e papel absorvente de cozinha, principalmente), além do papel de impressão. É nessa etapa que se introduz o dióxido de cloro, produzido pela AkzoNobel, que branqueia a fibra durante o processo de produção.

O conceito mais moderno de atuação no fornecimento de dióxido de cloro é o de Ilha Química. A empresa posiciona sua fábrica dentro das instalações do cliente, fornecendo seu produto via pipeline. Pode fornecer também ao cliente o serviço de tank farm, no qual compra, armazena e administra, diretamente no processo do cliente, um conjunto de produtos químicos. No Anexo 01, figura ilustrativa do conceito de Ilha Química. 


\subsubsection{Fatores de Risco para Monitoramento na Cadeia de Valor da Celulose} Transportando a literatura consultada para o caso do mercado de venda da fibra de celulose (ainda que fora do recorte da atividade da AkzoNobel, que é restrito ao branqueamento da fibra), diversos fatores de risco podem ser identificados e classificados como influenciadores da exposição ao risco. Como boa prática, pode ser interessante monitorá-los para identificação de tendências. Silva e Kopittke (2002) identificam os principais direcionadores de custo e suas participações no valor total da celulose. Tais direcionadores podem ser monitorados no processo de gerenciamento de risco corporativo.

Figura 18: Cadeia de Valor da Celulose - Composição de Custo - Fatores de Risco para Monitoramento
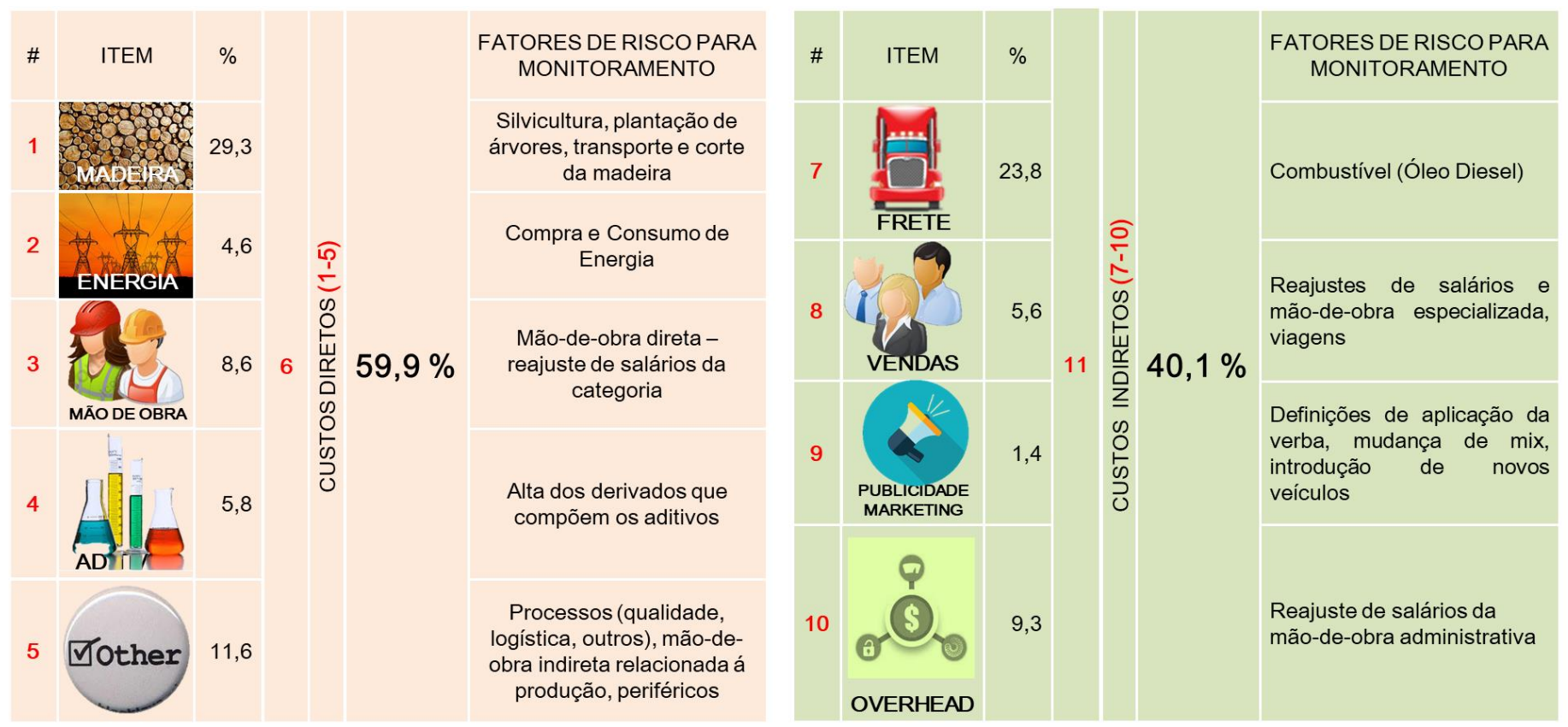

Fonte: adaptado de Silva e Kopittke (2002) 
Seguindo a lógica enumerada na Figura 18, temos os Custos Diretos (1-5) e Indiretos (7-10):

\begin{tabular}{|c|c|c|}
\hline & $\begin{array}{l}\text { Madeira } \\
1\end{array}$ & $\begin{array}{l}\text { A madeira utilizada como matéria-prima é o eucalipto. É uma madeira de baixo } \\
\text { custo na realidade industrial brasileira, fundamental para a vantagem } \\
\text { competitiva da cadeia da celulose. O fato de ser oriunda de manejo de recursos } \\
\text { naturais obriga à empresa cumprir várias legislações específicas, muitas vezes } \\
\text { de cunho não técnico, e sim político, como o trato das minorias silvícolas. O } \\
\text { manejo responsável na plantação, corte e reflorestamento também é alvo de } \\
\text { legislações e da mídia, e o transporte é um importante componente do custo, } \\
\text { especialmente considerando o baixo valor unitário agregado do material. }\end{array}$ \\
\hline & $\begin{array}{l}\text { Energia } \\
\quad 2\end{array}$ & $\begin{array}{l}\text { Uma única planta integrada, ou seja, produtor + fornecedores, consome cerca } \\
\text { de } 92 \mathrm{MW} / \text { mês, conforme Bachmann (2009). Para um termo de comparação, } \\
\text { em } 2009 \text {, o consumo médio de Energia Industrial no Brasil foi de } 13.483 \\
\text { MW/mês (EPE, 2016). Ou seja, uma planta sozinha corresponde a } 0,6 \% \text { do } \\
\text { consumo industrial total brasileiro. Em } 2016 \text { contabilizamos } 5 \text { plantas desse tipo, } \\
\text { produtoras da fibra de celulose, em Imperatriz - MA (Cia. Suzano de Papel e } \\
\text { Celulose); Eunápolis - BA (Veracel Celulose); Três Lagoas - MS (Eldorado } \\
\text { Brasil); Três Lagoas - MS (Fíbria Celulose) e Ortigueira - PR (Klabin Celulose). } \\
\text { As plantas são também geradoras intensivas de energia, devido às } \\
\text { características de seu processo. Geram a energia que consomem, além de } \\
\text { vender energia para o sistema. Dessa forma, os preços de Energia, que são } \\
\text { sempre sujeitos a intervenções governamentais, devem ser monitorados. }\end{array}$ \\
\hline & $\begin{array}{l}\text { Mão-de-Obra } \\
3\end{array}$ & $\begin{array}{l}\text { Os custos de mão-de-obra são monitorados especialmente em relação às } \\
\text { regulações e aos movimentos salariais. }\end{array}$ \\
\hline & $\begin{array}{c}\text { Aditivos } \\
4\end{array}$ & $\begin{array}{l}\text { Embora com participação pequena nos custos totais, são também monitorados } \\
\text { frequentemente. }\end{array}$ \\
\hline & $\begin{array}{l}\text { Outros } \\
5\end{array}$ & $\begin{array}{l}\text { Custos diversos relacionados à produção, mesmo com baixa participação } \\
\text { percentual sobre o custo total, precisam ser monitorados, de modo a evitar } \\
\text { surpresas. }\end{array}$ \\
\hline \multicolumn{2}{|c|}{$\begin{array}{l}\text { Custos Diretos } \\
6\end{array}$} & Soma dos itens 1 a 5 \\
\hline & $\begin{array}{c}\text { Frete } \\
7\end{array}$ & $\begin{array}{l}\text { Custos relacionados a Combustível, Mão-de-Obra e de mitigação quando } \\
\text { ocorrem paralisações dos serviços devem ser monitorados. }\end{array}$ \\
\hline & $\begin{array}{l}\text { Vendas } \\
\quad 8\end{array}$ & $\begin{array}{l}\text { Custos e verbas relativos à operação e desenvolvimento de Vendas devem ser } \\
\text { monitorados. }\end{array}$ \\
\hline & $\begin{array}{l}\text { Publicidade e } \\
\text { Marketing } \\
\quad 9\end{array}$ & $\begin{array}{l}\text { Custos e verbas relativos à operação e desenvolvimento de Publicidade e } \\
\text { Marketing devem ser monitorados. }\end{array}$ \\
\hline & $\begin{array}{l}\text { Overhead } \\
\quad 10\end{array}$ & $\begin{array}{l}\text { Cada componente relativamente importante na composição total, também são } \\
\text { monitorados como fatores de risco do negócio. }\end{array}$ \\
\hline \multicolumn{2}{|c|}{$\begin{array}{l}\text { Custos Indiretos } \\
11\end{array}$} & Soma dos itens 7 a 10 \\
\hline
\end{tabular}

\subsection{O negócio de Celulose no Brasil}

Nessa seção o autor não utilizará dados da organização, devido ao seu compromisso em não divulgar dados confidenciais. Entretanto, como em vários momentos desse 
estudo refere-se ao negócio de celulose como robusto e lucrativo, busca aqui dar um panorama de seu vigor no Brasil. Os dados demonstram números importantes, tanto em termos logísticos quanto em faturamento do setor frente ao PIB e valor exportado.

Figura 19: Celulose no Brasil - Exportação e Produção

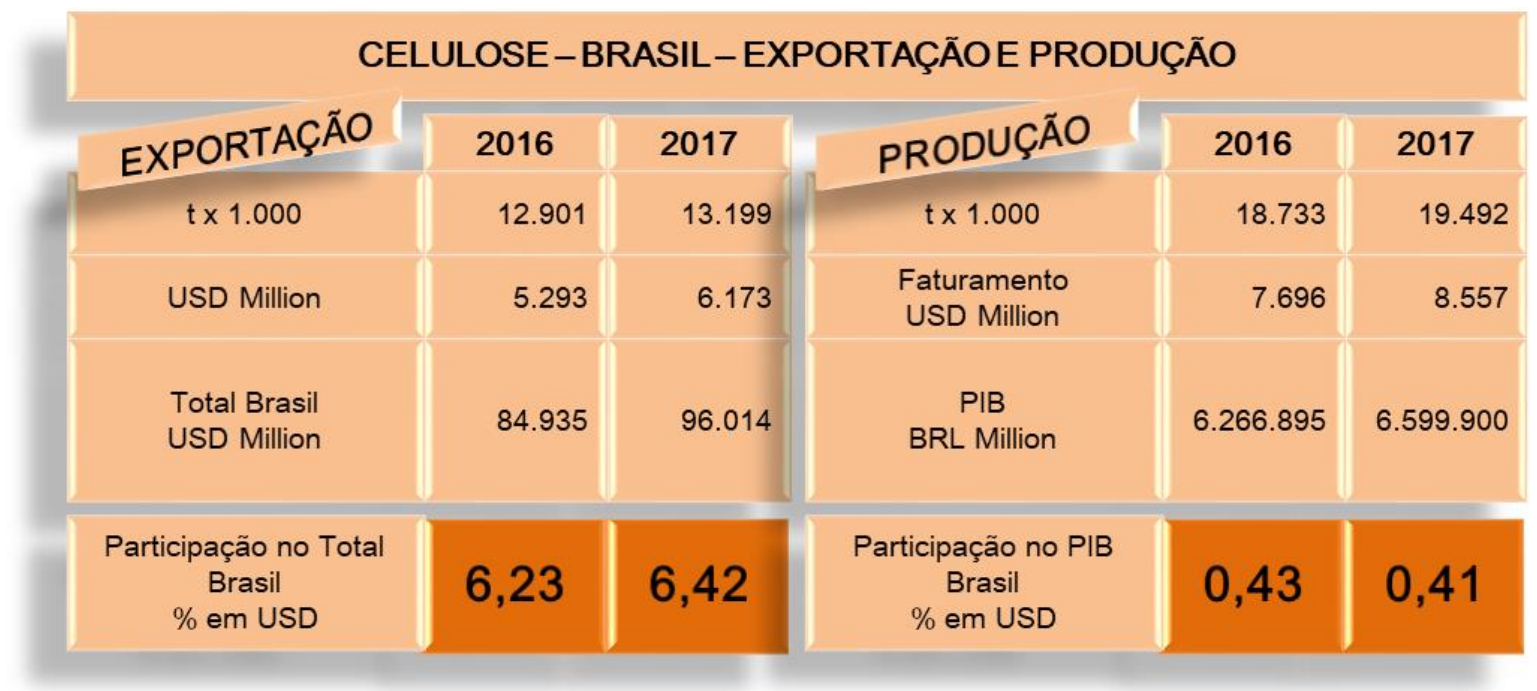

Fonte: IBÁ - Instituto Brasileiro de Árvores (2018)

O IBÁ (Instituto Brasileiro de Árvores) é um dos órgãos de confiança no setor de Papel e Celulose, razão pela qual foi utilizado como referência. Como se verifica na Figura 19, a produção de celulose em 2017 foi da ordem de 19 milhões de toneladas. Desse total, cerca de 13 milhões de toneladas foram exportadas. Historicamente os maiores clientes são China, Europa e América do Norte, que correspondem a aproximadamente $85 \%$ do total exportado. O setor faturou 8,5 bilhões de Dólares em 2017, o que corresponde a $0,41 \%$ do PIB brasileiro. As exportações no mesmo ano foram da ordem de 6 bilhões de dólares, correspondendo a $6,42 \%$ do valor total exportado pelo Brasil. Por tal robustez financeira e logística, o negócio está na pauta estratégica do governo brasileiro e dos investidores internacionais. A celulose é apontada como uma das grandes commodities nacionais, como afirma o Credit Suisse (2017). 


\section{MÉTODOS E TÉCNICAS}

O autor iniciou seu estudo através de Revisão Bibliográfica, acessando os temas Gerenciamento de Risco Corporativo e Avaliação de Maturidade Empresarial. O Gerenciamento de Risco Corporativo foi focado nas metodologias COSO (2013), ABNT ISO (2009) e Nohara et al. (2005), além de outras referências. No desenvolvimento, para análise do Gerenciamento de Risco Corporativo da AkzoNobel, o autor optou por contrapô-la a COSO (2013), desenvolvendo sua análise com base nesses parâmetros. Procedendo de forma similar, em relação à Avaliação de Maturidade Empresarial o autor acessou, dentre referências, o estudo de Poltronieri (2014), o artigo de Oliva (2016) e Hillson (1997). Nesse caso optou por avaliar a maturidade da AkzoNobel com base nos parâmetros de Oliva (2016).

Após a revisão bibliográfica e antes de decidir pelas metodologias mais adequadas para analisar o gerenciamento de risco corporativo na AkzoNobel, aplicou questionários aos responsáveis por diversas áreas relacionadas ao Supply Chain, ou ao seu suporte, nas quais existe já implementada a atividade de gerenciamento de risco corporativo ou um forte relacionamento. Assim, foram aplicados questionários às áreas do Supply Chain direto (Venda, Planejamento, Compras, Operações e Logística, Fornecedores e Clientes) e áreas de Suporte (Comunicação, IM - Information Management e Projetos \& Engenharia), num total de 15 questionários.

Os questionários em seu retorno foram avaliados qualitativamente, com base nas respostas obtidas de per si e na experiência do autor com o gerenciamento de risco corporativo na organização. Considerando a elaboração contra os parâmetros da metodologia COSO (2013) para gerenciamento de risco corporativo e do artigo de Oliva (2016) para avaliação de maturidade empresarial mais as respostas obtidas, o autor elaborou suas análises e validou-as com os principais agentes do processo na organização, quais sejam, os gerentes de Vendas, Operações, IM - Information Management e Projetos \& Engenharia.

Dentre os métodos existentes, o autor optou pelo estudo de caso e pela avaliação qualitativa. Tal escolha justifica-se pela proximidade do autor com os assuntos dentro da organização. Eventualmente uma pesquisa quantitativa poderia ter sido escolhida, 
mas o autor entendeu não existir um número suficientemente expressivo de respondentes (relacionados ao gerenciamento da empresa dentro dos limites especificados) para que se pudesse efetivar uma análise estatística sólida. Ainda, considerando que o objetivo do trabalho é apresentar uma análise, o autor considerou importante aplicar seus conhecimentos e sua experiência nas avaliações, uma vez que uma simples conclusão após uma análise numérica sem a devida ponderação poderia conduzir a pareceres equivocados.

\subsection{Justificativa para a Escolha pelo Método de Pesquisa Qualitativa}

A compilação de textos apresentada por Oliveira (2011) traz uma abrangente abordagem sobre Método Científico e Pesquisa Científica. Quando trata das Escolhas Metodológicas e Técnicas de Pesquisa (capítulo 3.1) descreve, sempre referenciado, os tipos de pesquisa (exploratória, descritiva e explicativa) e a natureza de pesquisa (qualitativa, quantitativa e qualitativa-quantitativa).

Por enxergar a pesquisa qualitativa como uma pesquisa exploratória, importante quando o que se busca é desenhar com razoável precisão um determinado cenário, que é o quadro geral do gerenciamento de risco corporativo da organização, para o autor, ao longo da elaboração dessa dissertação, essa mostrou-se a escolha mais adequada.

A vantagem sobre a pesquisa quantitativa é que a qualitativa permite um aprofundamento nas questões a serem respondidas, e não somente em resultados estatísticos. Também permite acessar, quando corretamente aplicada, o que o respondente pensa a respeito de uma determinada situação.

Como desvantagem, entretanto, podemos apontar a necessidade de interpretação, que deve ser muito cuidadosa para não permitir que o ponto de vista do autor distorça as respostas fornecidas. Na definição do público alvo, é necessário que se selecionem respondentes que consigam expressar-se adequadamente, permitindo a adequada interpretação das repostas. Ainda, a pesquisa qualitativa não conta com a regularidade que pode ser encontrada numa pesquisa quantitativa, o que ajuda por vezes a explicar tendências ou vislumbrar comportamentos futuros da variável analisada. 


\subsection{Validação de Pesquisa}

O atributo da pesquisa foi coletar pareceres de modo a possibilitar avaliar a percepção dos entrevistados sobre o gerenciamento de risco corporativo da AkzoNobel, bem como sua maturidade empresarial.

A população dos entrevistados foi definida considerando os agentes do Ambiente de Negócios da companhia, retratados na Figura 22: Riscos Empresariais no Ambiente de Valor. O autor considerou enviar o questionário a agentes importantes no processo de gerenciamento de risco da organização. Essa população, de acordo com os respondentes, foi assim agrupada:

- Clientes Principais.

Externo.

2 questionários

- Fornecedores Principais

Externo. 2 questionários

- Gerentes Comerciais. Interno. 3 questionários

- Gerentes e Coordenador do Supply Chain. Interno. 4 questionários

- Gerentes de Áreas de Suporte ao Negócio Interno. 4 questionários As perguntas foram relacionadas aos objetivos e aplicadas para respostas abertas, conforme se verifica na Matriz de Validação de Pesquisa abaixo. 


\begin{tabular}{|c|c|c|c|c|}
\hline \multicolumn{5}{|c|}{ MATRIZ DE VALIDAÇÃO DE PESQUISA } \\
\hline \multicolumn{5}{|c|}{$\begin{array}{l}\text { QUESTÃO DA PESQUISA: Como a empresa analisada, AkzoNobel, pode aumentar a eficácia do gerenciamento de riscos, adotando um modelo de } \\
\text { gerenciamento e aliando-o a um modelo de avaliação de maturidade? }\end{array}$} \\
\hline & OBJETIVOS & $\begin{array}{l}\text { REFERENCIAL } \\
\text { TEÓRICO }\end{array}$ & PARÂMETRO METODOLÓGICO & $\begin{array}{l}\text { PERGUNTA DO } \\
\text { QUESTIONÁRIO(Parte 1) }\end{array}$ \\
\hline \multirow{9}{*}{ 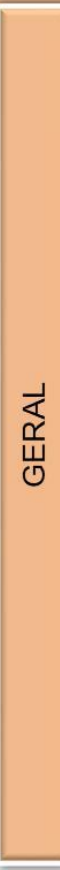 } & \multirow{9}{*}{$\begin{array}{l}\text { Analisar o gerenciamento } \\
\text { de risco praticado na } \\
\text { empresa AkzoNobel, em } \\
\text { seu negócio de Celulose } \\
\text { no Brasil. }\end{array}$} & \multirow{9}{*}{ coso (2013). } & $\begin{array}{l}\text { A Alta Direção demonstra independência da gerência e } \\
\text { exerce supervisão sobre o desenvolvimento e desempenho } \\
\text { dos controles internos. }\end{array}$ & 1 \\
\hline & & & $\begin{array}{l}\text { A organização mantém profissionais responsáveis por seus } \\
\text { controles internos para atingimento de seus objetivos. }\end{array}$ & 2 \\
\hline & & & $\begin{array}{l}\text { A organização especifica seus objetivos com clareza } \\
\text { suficiente para habilitar a identificaçâo e avaliaçâo dos } \\
\text { riscos relacionados aos objetivos. }\end{array}$ & 3 \\
\hline & & & $\begin{array}{l}\text { A organização considera fraudes em potencial quando } \\
\text { avaliando riscos relacionados aos atingimentos dos } \\
\text { objetivos. }\end{array}$ & 4 \\
\hline & & & $\begin{array}{l}\text { A organização obtém ou gera, e utiliza, informaçöes de } \\
\text { qualidade relevante para suportar a operação dos controles } \\
\text { internos }\end{array}$ & 5 \\
\hline & & & $\begin{array}{l}\text { A organização divulga informações internamente, incluindo } \\
\text { os objetivos e responsabilidades dos controles internos, } \\
\text { necessárias para suportar sua operação. }\end{array}$ & $6 ; 13$ \\
\hline & & & $\begin{array}{l}\text { A organização divulga extrernamente informações } \\
\text { relacionadas a ocorrências que afetem a operação dos } \\
\text { controles internos. }\end{array}$ & $9 ; 10 ; 11$ \\
\hline & & & $\begin{array}{l}\text { A organização seleciona, desenvolve e executa ações } \\
\text { durante a operaçâo elou em avaliaçôs separadas se os } \\
\text { componentes dos controles internos estâa presentes e } \\
\text { funcionando. }\end{array}$ & 12 \\
\hline & & & $\begin{array}{l}\text { A organização avalia e comunica as deficiências dos } \\
\text { controles internos de maneira oportuna às partes } \\
\text { responsáveis por tomar açoes corretivas, incluindo a Alta } \\
\text { Gerência e a Alta Direçâa, se apropriado. }\end{array}$ & 5 \\
\hline \multirow{4}{*}{ 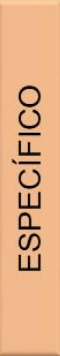 } & \multirow{4}{*}{$\begin{array}{l}\text { Identificar e analisar os } \\
\text { principais riscos } \\
\text { corporativos na cadeia de } \\
\text { valor, com foco em } \\
\text { Supply Chain. }\end{array}$} & \multirow{4}{*}{$\begin{array}{l}\text { Silva e Kopittke } \\
\quad(2002)\end{array}$} & $\begin{array}{l}\text { Riscos ligados à silvicultura, agricultura e transporte de } \\
\text { madeira in natura. }\end{array}$ & $8 ; 10 ; 11$ \\
\hline & & & Riscos ligados à compra e consumo de Energia Elétrica. & $8 ; 10 ; 11$ \\
\hline & & & $\begin{array}{l}\text { Riscos ligados a Mäo-de-Obra, especialmente àquela } \\
\text { contratada localmente., incluindo-se aí a Mão-de-Obra } \\
\text { administrativa. }\end{array}$ & 7 \\
\hline & & & $\begin{array}{l}\text { Riscos ligados a alterações de preços de produtos } \\
\text { químicos e combustiveis. }\end{array}$ & 7 \\
\hline \multirow{9}{*}{ 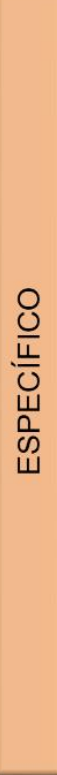 } & \multirow{9}{*}{$\begin{array}{l}\text { Avaliar o nível de } \\
\text { maturidade da empresa } \\
\text { no gerenciamento de } \\
\text { riscos corporativos. }\end{array}$} & \multirow{9}{*}{ Oliva (2016) } & Grau de Consciência em Gerenciamento de Risco. & $1 ; 2 ; 3$ \\
\hline & & & $\begin{array}{l}\text { Nivel de estrutura física e conceitual estabellecidas para o } \\
\text { Gerenciamento de Risco. }\end{array}$ & $4 ; 5 ; 6 ; 7 ; 9$ \\
\hline & & & $\begin{array}{l}\text { Nivel de utilização de técnicas, ferramentas e métodos de } \\
\text { Gerenciamento de Risco. }\end{array}$ & $8 ; 10$ \\
\hline & & & $\begin{array}{l}\text { Grau de envolvimento dos colaboradores em geral nas } \\
\text { atividades de Gerenciamento de Risco. }\end{array}$ & 11 \\
\hline & & & $\begin{array}{l}\text { Grau de organização dos processos relacionados a } \\
\text { Gerenciamento de Risco. }\end{array}$ & $2 ; 6 ; 7 ; 9$ \\
\hline & & & $\begin{array}{l}\text { Grau de centralização das atividades de Gerenciamento de } \\
\text { Risco. }\end{array}$ & 5 \\
\hline & & & $\begin{array}{l}\text { Importância da Comunicação interna e externa nos } \\
\text { processos de Gerenciamento de Risco. }\end{array}$ & $12 ; 13$ \\
\hline & & & $\begin{array}{l}\text { Utilização de expertise externa (consultorias e parceiros) } \\
\text { em seu processo de Gerenciamento de Risco. }\end{array}$ & 14 \\
\hline & & & $\begin{array}{l}\text { Avaliação de risco transcendente ao ambiente de valor da } \\
\text { companhia (interno), inlcuindo o ambiente de negócio } \\
\text { (externo). }\end{array}$ & 15 \\
\hline
\end{tabular}


A pesquisa foi elaborada conforme o diagrama abaixo e conforme etapas já explicadas anteriormente:

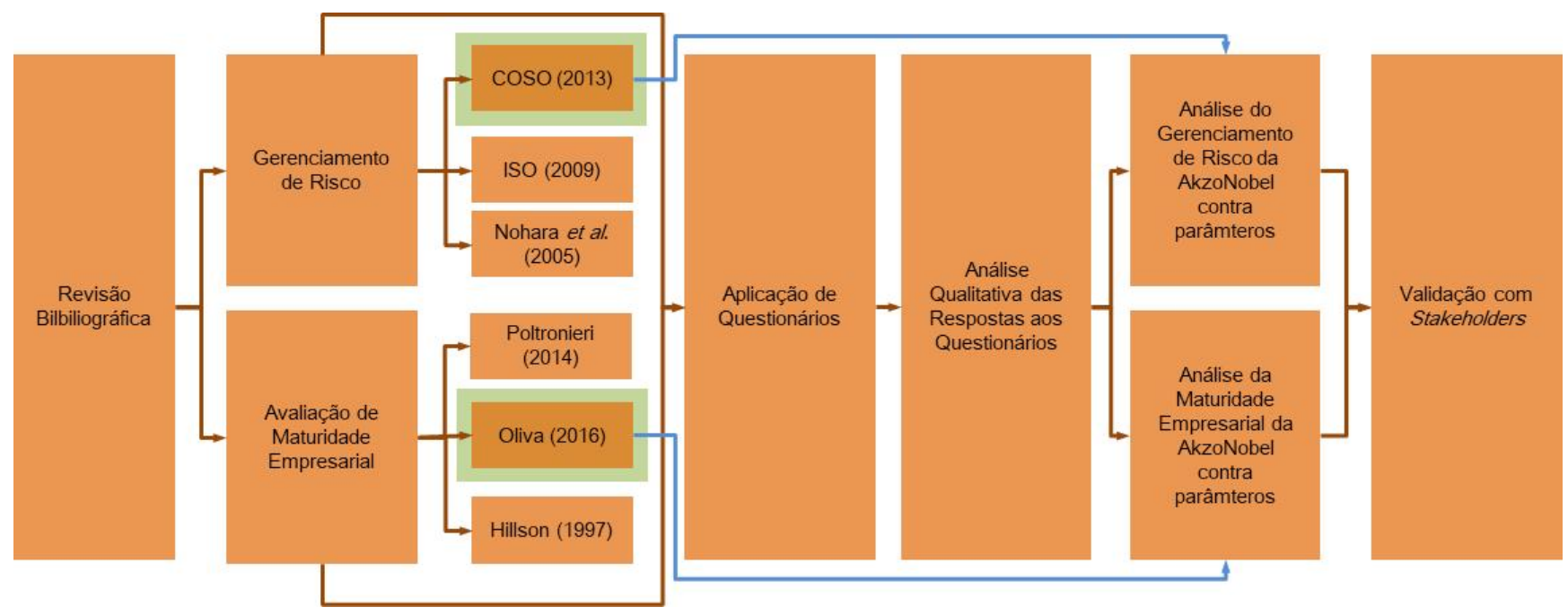

O autor inicialmente realizou a Revisão Bibliográfica, buscando obras relevantes e também de elaboração mais recente, concluindo então que sua pesquisa deveria ser dividida pelas áreas de Gerenciamento de Risco Corporativo e Avaliação de Maturidade Empresarial. Na área de Gerenciamento de Risco Corporativo encontrou as referências mais aderidas à sua pesquisa em COSO (2013), ABNT ISO (2009) e Nohara et al. (2005). Conforme justificado em 2.3.4, prosseguiu com a abordagem COSO (2013), baseando-se nela para elaboração das perguntas da etapa 1 do questionário. Para Avaliação de Maturidade Empresarial, as referências mais aderidas foram Poltronieri (2014), Oliva (2016) e Hillson (1997). Conforme justificado em 2.4.4, prosseguiu com a abordagem de Oliva (2016), baseando-se nela para a elaboração da etapa 2 do questionário. Elaborado o instrumento, procedeu com a Aplicação do Questionário, dirigido interna e externamente à organização. No retorno o autor procedeu à Análise Qualitativa das Respostas aos Questionários, detalhada no item 6, realizando a Análise do Gerenciamento de Risco Corporativo contra os parâmetros COSO (2013) e a Análise da Maturidade Empresarial contra os parâmetros de Oliva (2016). De posse desses resultados procedeu à Validação com os stakeholders, quais sejam: os gerentes de Vendas, Operações, IM - Information Management e Projetos \& Engenharia. 
O objetivo geral de analisar o gerenciamento de risco corporativo praticado na empresa AkzoNobel, em seu negócio de celulose no Brasil foi relacionado ao material de COSO (2013), e traz perguntas baseadas em princípios mais genéricos, embora bem aderidos ao negócio da companhia.

O objetivo específico de Identificar e analisar os principais riscos corporativos na cadeia de valor, com foco em Supply Chain foi relacionado a Silva e Kopittke (2002) e é específico da área de Celulose, extraído de um artigo bastante detalhado escrito pelos profissionais do setor.

O outro objetivo específico, avaliar o nível de maturidade da empresa no gerenciamento de risco corporativo, foi relacionado a Oliva (2016), possibilitando, através dos preceitos determinados para cada cluster, a realização de perguntas que permitiram chegar à avaliação desejada.

Ao final do instrumento foi adicionado um espaço para comentários. O Questionário aplicado pode ser verificado no Apêndice 01 . 


\section{ANÁLISE DOS DADOS}

\subsection{Gerenciamento do Risco Corporativo e Avaliação de Maturidade na} AkzoNobel

Os conceitos de Gerenciamento do Risco Corporativo e Avaliação de Maturidade Empresarial foram aplicados ao estudo da realidade da AkzoNobel, conforme recorte declinado.

Como resultado o autor disponibiliza análise do gerenciamento de risco corporativo praticado pela organização e avalia seu nível atual de maturidade, focando o Supply Chain.

\subsubsection{Gerenciamento de Risco Corporativo na AkzoNobel}

A empresa, dentro do recorte declinado, não possui exatamente uma estrutura de gerenciamento de risco corporativo. Cada processo de negócio é instado a avaliar seus riscos anualmente através de uma metodologia simples e direta, composta por planilhas de levantamento de informações, o respectivo tratamento indicado aos riscos apontados e follow-up das ações. Não há também um trabalho especificamente direcionado para a Avaliação de Maturidade Empresarial. A prática é funcional e sistematizada, mas bastante adaptada, não destoando, no entanto, de orientações clássicas encontradas na literatura, como afirma Willians et. al (2006, p. 67-86): "Gerenciamento de Risco visa prover tomadores de decisão com uma abordagem sistemática para lidar com riscos e incertezas."

Para o processo de Suprimentos, a avaliação é baseada nas matérias-primas que alimentam o processo produtivo e nos materiais relativos à manutenção e investimento em Operações. Conforme demonstrado na Figura 20, o fluxo a ser seguido é bastante simples. 
Figura 20: Fluxo de Gerenciamento de Risco Corporativo da AkzoNobel

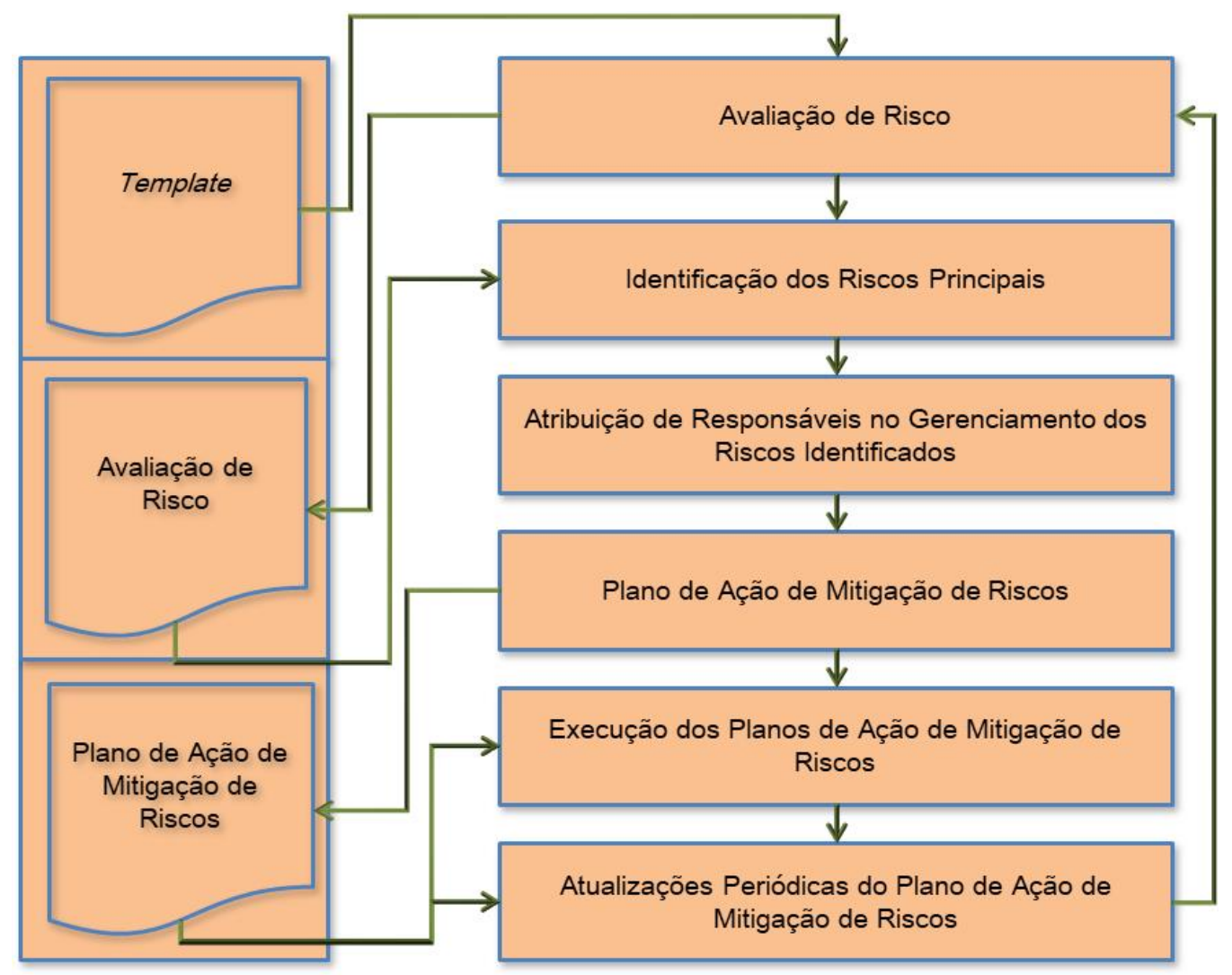

Fonte: adaptada do material global de Risk Mitigation Plan da Akzonobel (2016)

O processo é cíclico. Há um template de Avaliação de Risco a ser preenchido. Através desse documento obtém-se a Identificação dos Riscos Principais, e em seguida realizase a Atribuição de Responsáveis no Gerenciamento dos Riscos Identificados. Cada um dos responsáveis identifica as ações mitigatórias para cada risco, dando origem ao Plano de Ação de Mitigação de Riscos. Realizado o Plano, passa-se à Execução dos Planos de Ação de Mitigação de Riscos. O grupo de responsáveis por função executiva deve reunir-se para Atualizações Periódicas do Plano de Ação de Mitigação de Riscos, o que confere um caráter cíclico ao processo. Essa atualização serve de base para o próximo ciclo de Avaliação de Risco.

\subsubsection{Avaliação de Risco}

O documento de Avaliação de Risco é baseado nos seguintes critérios:

- Criticidade de Fornecimento - $\mathrm{N}^{\circ}$ de fornecedores aprovados para o item. Quanto menor o número de fornecedores, mais alta a criticidade; 
- Facilidade de substituição do Material - Material comprado com especificação especial para a AkzoNobel ou item de "prateleira". Quanto mais específico, mais alta a criticidade;

- Tempo de substituição do Material - Além da compra em si, são necessários testes e adaptações que demandam tempo, que será estimado em número de meses. Quanto maior o time fence, mais alta a criticidade.

A combinação de fatores determina o grau de risco. $O$ resultado da multiplicação do $\mathrm{N}^{\circ}$ de Fornecedores Aprovados x Material Especialmente Especificado ou de Prateleira $\mathrm{x}$ Tempo de Substituição do Material, comparada a uma tabela de parâmetros, determina se o Risco é Baixo, Médio ou Alto.

\subsubsection{Plano de Ação de Mitigação de Riscos}

O conteúdo de cada Plano de Ação de Mitigação foi composto com base em melhores práticas, e contém:
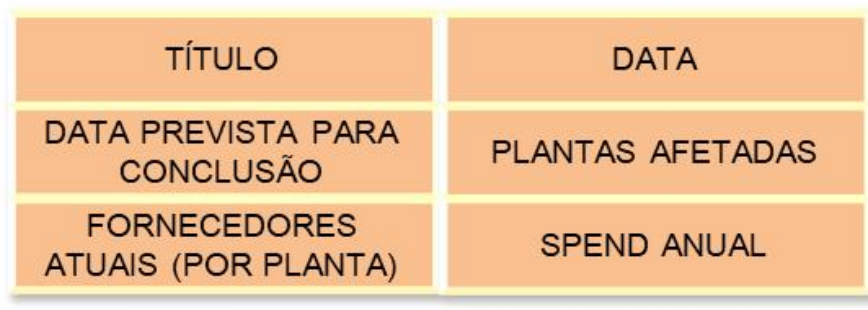

STAKE HOLDERS

DESCRITIVO DA SITUAÇÃO ATUAL

AÇÕES

Cada uma das Ações detalhadas contém:

\begin{tabular}{|c|c|}
\hline AÇÃO & RESPONSÁVEL \\
\hline DATA DE CONCLUSÃO & STATUS \\
\hline
\end{tabular}

\subsubsection{Análise de Portfólio}

Complementarmente, com o intuito de manter a Alta Direção informada e facilitar uma eventual tomada de decisão, é realizada uma análise de portfólio para cada negócio, acrescentando-se, nesse caso, o potencial de comprometimento de margem em caso de ocorrência dos riscos identificados. A análise também é baseada em benchmark, principalmente baseado em Cooper (1999), gerando um output como o verificado na Figura 21: 
Figura 21: Análise de Portfólio

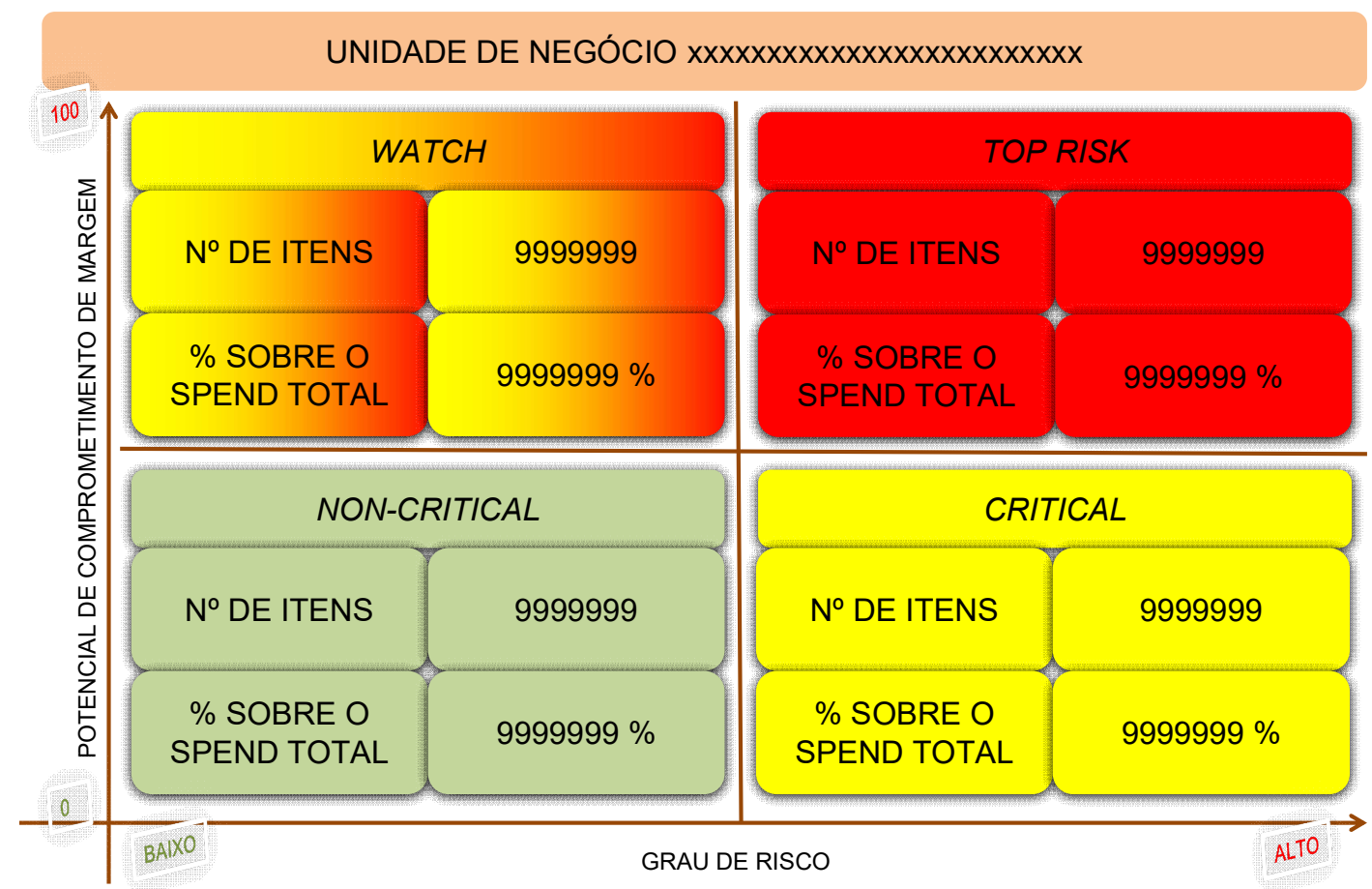

Fonte: adaptada do material global de Risk Mitigation Plan da AkzoNobel (2016)

A Unidade de Negócio analisada é identificada. A análise de portfólio visa classificar os materiais analisados em 4 quadrantes, plotados nos cruzamentos dos eixos $Y$ (Potencial de Comprometimento de Margem), evoluindo de 0 a $100 \%$, no qual se estima o impacto de cada quadrante sobre a margem total de contribuição da organização, e X (Grau de Risco), evoluindo de Baixo para Alto. Quanto mais alto o potencial de comprometimento da margem e quanto mais alto o grau de risco, mais demandante de atenção é o item. $O$ quadrante Non-Critical (Não Crítico) é, teoricamente, o menos demandante de atenção, pois tem potencial de comprometimento e risco baixos. Significa que, para os produtos nele classificados, há mais que um fornecedor para o mesmo material, há disponibilidade, a evolução de preços tem uma determinada coerência e/ou previsibilidade, o processo não é extremamente dependente do material, podendo substituí-lo com certa facilidade, e não há previsões de grandes alterações desse quadro para o futuro. $\mathrm{O}$ item preenche todos esses requisitos, ou a maioria deles. O quadrante Critical (Crítico) demanda alguma atenção, pois um ou mais desses requisitos não está equilibrado, podendo causar algum balanço no fornecimento não agora, mas num futuro próximo, o que faz com que o 
potencial de comprometimento permaneça baixo, mas o risco suba de médio para alto. $\mathrm{O}$ quadrante Watch (Vigie) demanda atenção imediata ou num futuro próximo para requisitos cruciais de fornecimento, especialmente se falarmos sobre disponibilidade, preço, dificuldade de troca e dependência do processo, já que, embora com risco relativamente baixo, traz potencial de comprometimento alto em caso de alguma ocorrência. O quadrante Top Risk (Alto Risco) contem os materiais cruciais para a continuidade operacional da companhia, e precisa ter todos os requisitos mencionados monitorados constantemente, já que tem o potencial de comprometimento e o risco classificados como altos. Em cada quadrante, para o demonstrativo gráfico, coloca-se ainda o $\mathrm{N}^{\circ}$ de Itens ali classificados e o percentual daquele quadrante sobre o Spend Total.

\subsubsection{Principais Tipos de Risco aos quais a AkzoNobel Está Exposta}

O negócio de Celulose é realmente bastante singular, considerando que mistura a instalação de imensos sites produtivos e a venda de imensas quantidades de fibra de celulose com o fato de ser um negócio baseado em manejo de recursos naturais. Detalhando um pouco mais o que se verifica na Figura 18 (Cadeia de Valor da Celulose Composição de Custo - Fatores de Risco para Monitoramento) e no texto sequente, são significativos os fatores de monitoramento de risco, internos e externos. A maior parte diz respeito aos negócios dos clientes, mas afetam irremediavelmente as operações de nossas plantas neles instaladas (Econoinfo, 2017). Podemos considerar, como Riscos Externos:

- Preço Internacional da Celulose: sua flutuação faz com que o cliente adeque sua produção para cima ou para baixo, afetando à puxada do produto de nossa fábrica;

- Condições do mercado internacional, gerando crises em grandes consumidores de celulose como Estados Unidos, União Europeia e alguns países asiáticos, afetando a capacidade de exportação do cliente e, consequentemente, sua produtividade;

- Volatilidade do Real x Dólar, que pode impactar às receitas dos clientes fortemente dependentes de exportações, afetando sua produtividade e capacidade de investimentos; 
- Condições da economia interna, como inflação e altas nas taxas de juros, que podem impactar às receitas dos clientes, afetando sua produtividade e capacidade de investimentos.

Os Riscos Internos, por sua vez, direcionam para:

- Situação financeira do cliente, deficitária por diversas razões, como crédito, encerramentos de benefícios fiscais, disputas trabalhistas, etc., que pode comprometer capacidade de produção imediata e investimentos futuros;

- Disponibilidade de matéria-prima (madeira): os clientes buscam sempre o abastecimento por florestas próprias, para garantir constância de suprimento e qualidade. Quando é necessário recorrer a produtores independentes, sua produtividade pode ser afetada por preço ou qualidade, trazendo flutuações à sua produção e afetando à puxada do produto de nossa fábrica;

- Causas naturais que afetem áreas próprias de plantio de madeira, como pragas desconhecidas às quais as árvores, apesar de geneticamente modificadas, ainda não são resistentes, incêndios florestais e secas, que provocam a necessidade de madeira independente, o que pode afetar os custos e a produtividade do cliente;

- Trato com as minorias silvícolas: remarcações de terras, alteração no modo de vida dessas populações, surgimento de problemas advindos de contingentes vindos de todo o país atraídos pelas novas instalações, com hábitos e doenças que possam afetá-los, e que podem trazer imensos custos indenizatórios ou de responsabilidade civil e danos permanentes à imagem do cliente e de seus fornecedores;

- Regulação ambiental: as exigências iniciais de per si já trazem custos significativos para as plantas como um todo. A introdução de novas regulações com a atividade já em andamento podem trazer desembolsos em adequações que afetem o resultado da organização, comprometendo produtividade e investimentos;

Considerando novamente a Figura 22: Riscos Empresariais no Ambiente de Valor, destacam-se respondentes entre os seguintes agentes, agora sinalizadas em amarelo: 
Figura 22: Riscos Empresariais no Ambiente de Valor - Grupos Respondentes do Questionário

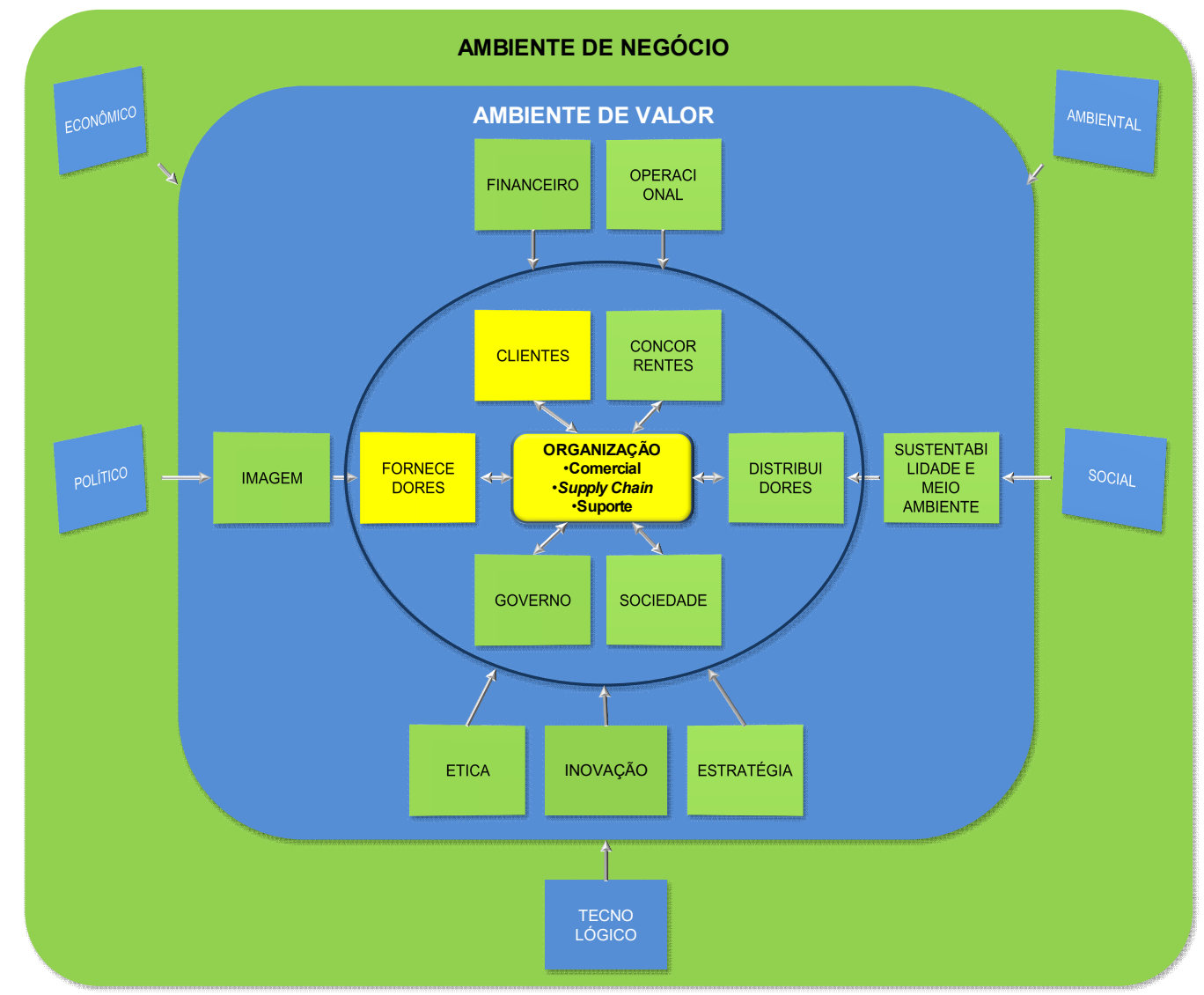

Fonte: adaptado de Oliva (2016)

O autor analisou as respostas, encaixando-as na Matriz de Validação de Pesquisa. Assim, para a análise do Gerenciamento de Risco Corporativo utilizou os parâmetros COSO (2013) complementados por parâmetros do risco específico do negócio de celulose com base em Silva e Kopittke (2002). Essa seção foi chamada de Gerenciamento de Risco. Para a Avaliação de Maturidade Empresarial foram utilizados os parâmetros de Oliva (2016), na seção chamada de Avaliação de Maturidade.

Com cuidado, o autor simplificou as respostas na apuração, uma vez que eram abertas, buscando categorizá-las. Então, "Não tenho conhecimento"; "Não sei responder"; ou sem resposta viraram "Não Sei", e assim por diante, pois no contexto sinalizam basicamente a mesma percepção de falta de informação.

O autor agrupou os respondentes em grupos afins (Clientes; Fornecedores; Comercial; Supply Chain; Suporte). As respostas podem ser verificadas nos Apêndices 02 e 03. 


\subsection{Gerenciamento de Risco Corporativo - Análise das Respostas aos Questionários - Parte 1}

Em relação a Gerenciamento de Risco Corporativo, o autor buscou cercar, com as perguntas, os Parâmetros Metodológicos de COSO (2013). Como contribuição, o autor acrescentou elementos presentes no artigo de Silva e Kopittke (2002), específicos do segmento de Celulose. Na Tabela 01, a avaliação das respostas compiladas e, em itálico, as considerações do autor baseadas em seu conhecimento e experiência com a atividade de gerenciamento de risco corporativo na organização.

Tabela 01: Análise das Respostas aos Questionários - Parte 1

\section{PARÂMETRO}

A Alta Direção demonstra independência da gerência e exerce supervisão sobre o desenvolvimento e desempenho dos controles internos.

A organização mantém profissionais responsáveis por seus controles internos para atingimento de seus objetivos.

A organização especifica seus objetivos com clareza suficiente para habilitar a identificação e avaliação dos riscos relacionados aos objetivos.

A organização considera fraudes em potencial quando avaliando riscos relacionados aos atingimentos dos objetivos. informações de qualidade relevante para suportar a operação dos controles internos.

\section{AVALIAÇÃO DO AUTOR}

À exceção de um, os respondentes internos e externos entendem que a Alta Direção da empresa demonstra independência da gerência e exerce supervisão sobre o desenvolvimento e desempenho dos controles internos.

A Alta Direção de fato é independente da gerência e supervisiona o desenvolvimento e o desempenho dos controles internos.

Os clientes demonstraram não ter a informação. Os fornecedores, talvez pela proximidade com setores da empresa como Contas a Pagar tiveram percepção oposta. Internamente, há um ponto de melhoria.

A empresa possui efetivamente um time exclusivo para tal função, mas alguns respondentes demonstraram não saber ou afirmaram que esse time não existe.

A maioria dos respondentes externos respondeu afirmativamente. Internamente, poucos respondentes disseram que não, mas a maioria entende que a empresa o faz de forma parcial, para riscos específicos.

Essa última impressão é a que realmente corresponde ao modus operandi da empresa.

Os clientes responderam não possuir a informação. Os fornecedores responderam afirmativamente, o que é natural considerando que são sempre envolvidos em nossas verificações e auditorias. Alguns respondentes internos alegam não ter conhecimento da informação.

A organização possui, sim, a política de avaliar fraudes em potencial quando avalia riscos. Por isso, inclusive, implementou uma abrangente política de Compliance que é outorgada a todos os colaboradores.

A maior parte dos respondentes internos e externos tem a percepção que sim.

A organização possui um robusto banco de dados, com base em seu ERP, e gera informações de qualidade que suportam seus controles internos. 
A organização divulga informações internamente, incluindo os objetivos e responsabilidades dos controles internos, necessárias para suportar sua operação.

A organização divulga externamente informações relacionadas a ocorrências que afetem a operação dos controles internos.

A organização seleciona, desenvolve e executa ações durante a operação e/ou em avaliações separadas se os componentes dos controles internos estão presentes e funcionando.

A organização avalia e comunica as deficiências dos controles internos de maneira oportuna às partes responsáveis por tomar ações corretivas, incluindo a Alta Gerência e a Alta Direção, se apropriado.

- Riscos ligados à silvicultura, agricultura e transporte de madeira in natura.

- Riscos ligados à compra e consumo de Energia Elétrica.

- Riscos ligados a Mão-de-Obra, especialmente àquela contratada localmente, incluindo-se aí a Mão-deObra administrativa.

- Riscos ligados a alterações de preços de produtos químicos e combustíveis.
Os clientes e fornecedores não souberam responder, uma vez que a pergunta trata da divulgação interna de informações. Internamente, alguns respondentes não souberam responder, e outros responderam ter informações mais restritas às suas áreas.

A organização tem uma política de comunicação bastante aberta e democrática. Entretanto, não há nada formalizado ou estruturado para esse quesito específico.

Os respondentes internos e externos reconhecem, em sua maioria, que a organização pratica uma relação de parceria com seus agentes. Os respondentes externos, entretanto, não reconhecem que a organização comunique externamente ocorrências relacionadas a controles internos.

A organização não tem como prática realizar esse tipo de comunicação.

Única resposta unânime, em que os respondentes externos e internos concordaram que a organização de fato avalia adequadamente a presença e funcionamento de seus controles internos.

A organização avalia, durante a operação ou com checagens específicas, a presença e funcionamento de seus controles internos.

A maior parte dos respondentes internos e externos tem a percepção que a organização o faz adequadamente.

A organização possui um robusto banco de dados, com base em seu ERP, e gera informações de qualidade que suportam seus controles internos, e constantemente investe em melhoria.

Os clientes responderam que, dentro do negócio, a organização está submetida a riscos de perdas de oportunidades e riscos de operação, mas não sabem responder se a empresa está preparada para lidar com eles. Os fornecedores não souberam elencar riscos da empresa dentro do negócio, e enquanto um não soube responder se a empresa está preparada para gerenciá-los, o outro afirma que sim. Os respondentes internos elencaram riscos visíveis dentro de suas atividades, a saber: Logística, Supply Chain, Tecnologia, Fraudes, Econômicos, Operacionais, Capital Humano, Ambientais, Governamentais, Comunicação e Imagem, e dividem sua percepção entre a empresa estar apta a lidar com seus riscos externos, ou estar apta a lidar parcialmente com seus riscos externos.

A organização trata os riscos mais imediatos ao negócio, especialmente no Supply Chain, de forma bastante efetiva, mapeando cada um dos materiais se serviços importantes à sua operação e atuando eficientemente na mitigação de tais riscos. Outros riscos são monitorados através de informações, mas não são passíveis de ações diretas.

A percepção interna e externa é de que empresa está preparada para ligar com seus riscos internos, se não na totalidade, ao menos parcialmente.

A organização trata os riscos mais imediatos ao negócio, especialmente no Supply Chain, de forma bastante efetiva, mapeando cada um dos materiais se serviços importantes à sua operação e atuando eficientemente na mitigação de tais riscos. Trata também de forma muito cuidadosa os riscos relacionados ao Capital Humano.

Fonte: autoria própria (2017) 


\title{
5.2.1. Gerenciamento de Risco Corporativo - Comparativo com a parametrização COSO (2013)
}

\author{
O autor realizou essa análise baseado em sua própria experiência na organização \\ ponderando-a com as respostas perceptivas obtidas dos respondentes internos à Parte 1 \\ do Questionário e comparando-as aos parâmetros COSO (2013). Na coluna da esquerda \\ encontram-se os parâmetros COSO (2013) e na da direita a avaliação do autor.
}

\subsubsection{Ambiente de Controle}

Parâmetro COSO (2013)

Avaliação do Autor

1. A organização demonstra compromisso com integridade e valores éticos. A organização demonstra compromisso com integridade e valores éticos, seja pelo histórico da organização, seja por seu comportamento junto das interfaces, seja pelas políticas de conduta e compliance estabelecidas.

2. A Alta Direção demonstra independência da gerência e exerce supervisão sobre o desenvolvimento e desempenho dos controles

A Alta Direção demonstra independência da gerência e exerce supervisão sobre o desenvolvimento e desempenho dos controles internos.

3. A Administração estabelece, com supervisão da Alta Direção, estruturas, linhas de reporte, e delega autoridade e internos, tendo controles regulares implementados para tal. responsabilidades na busca dos objetivos.

4. A organização demonstra compromisso para atrair, desenvolver e reter profissionais competentes em alinhamento com seus objetivos.

A Administração estabelece, com supervisão da Alta Direção, estruturas, linhas de reporte, e delega autoridade e responsabilidades na busca dos objetivos, mantendo na intranet e em outros meios um desenho claro de tal estrutura.

A organização mantém profissionais responsáveis por seus controles internos para atingimento de seus objetivos.

A organização demonstra compromisso para atrair, desenvolver e reter profissionais competentes em alinhamento com seus objetivos, através de políticas de RH alinhadas com empresas de seu porte nos mercados estabelecidos.

A organização mantém profissionais responsáveis por seus controles internos para atingimento de seus objetivos, estabelecendo claramente suas atividades e responsabilidades.

No Ambiente de Controle a organização demonstra integridade e ética, uma Alta Direção atuante, independentemente das outras camadas hierárquicas, suporta à Administração que, por sua vez, estabelece linhas de reporte e autoridade, compromete-se a reter recursos humanos e mantém profissionais dedicados a controles internos. 


\subsubsection{Avaliação de Riscos}

Parâmetro COSO (2013)

Avaliação do Autor

6. A organização especifica seus objetivos com clareza suficiente para habilitar a identificação e avaliação dos riscos relacionados aos objetivos.

7. A organização identifica riscos no atingimento de seus objetivos através da entidade, e analisa riscos como base para determinar como devem gerenciados.

8. A organização considera fraudes em potencial quando avaliando riscos relacionados aos atingimentos dos objetivos.

A organização especifica seus objetivos com clareza suficiente para habilitar a identificação e avaliação dos riscos relacionados aos objetivos, para parte de seus objetivos. Ainda não existe uma abrangência completa que possibilite afirmar que todos os riscos estejam cobertos

A organização identifica riscos no atingimento de seus objetivos através da entidade, e analisa riscos como base para determinar como devem gerenciados, para parte de seus riscos. Também nesse caso a abrangência não é suficientemente completa para que se possa garantir que todos os riscos estejam cobertos.

A organização considera fraudes em potencial quando avaliando riscos relacionados aos atingimentos dos objetivos, tendo estabelecido para isso controles internos e auditorias externas e internas.

9. A organização identifica e A organização identifica e avalia mudanças que podem afetar avalia mudanças que podem significativamente o sistema de controles internos, seja através da afetar significativamente o divulgação interna de best practices, constante aprimoramento sistema de controles internos. dos colaboradores e benchmarks e consultorias externas.

$\mathrm{Na}$ Avaliação de Riscos, os objetivos são especificados com clareza e relacionados aos riscos, mas não se pode afirmar que a abrangência se estenda a todos os riscos. Fraudes em potencial são consideradas, e estão estabelecidos controles internos e auditorias visando sua mitigação, além de monitoramento de mudanças no ambiente de valor que possam afetar o desempenho ou o próprio sistema de controles internos.

\subsubsection{Atividades de Controle}

Parâmetro COSO (2013)

10. A organização especifica seus objetivos com clareza suficiente para habilitar a identificação e avaliação dos riscos relacionados aos objetivos.

11. A organização seleciona e desenvolve atividades gerais de controle com tecnologia, para suportar o atingimento dos objetivos.

12. A organização desdobra as atividades de controle através de políticas que estabelecem o que é esperado e procedimentos que transformam políticas em ações.
Avaliação do Autor

A organização especifica seus objetivos com clareza suficiente para habilitar a identificação e avaliação dos riscos relacionados aos objetivos, para parte de seus objetivos. Ainda não existe uma abrangência completa que possibilite afirmar que todos os riscos estejam cobertos.

A organização seleciona e desenvolve atividades gerais de controle com tecnologia, para suportar 0 atingimento dos objetivos, através da adoção um robusto ERP aliado a sistemassatélite de funções específicas. Mantém também, em seus quadros, profissionais de IT e IM para suportar operações e projetos.

A organização desdobra as atividades de controle através de políticas que estabelecem o que é esperado e procedimentos que transformam políticas em ações, mantendo em sua rede interna um arcabouço específico e organizado de documentos e procedimentos que suportam as atividades e definições de responsabilidades.

No tocante às Atividades de Controle, os objetivos são especificados com clareza e relacionados aos riscos, mas não se pode afirmar que a abrangência se estenda a todos 
os riscos. A organização mantém suporte adequado às atividades de controle interno, e mantém políticas q procedimentos que permitem organizá-las e padronizá-las.

\subsubsection{Informação e Comunicação}

Parâmetro COSO (2013)

Avaliação do Autor

\begin{tabular}{|c|c|}
\hline $\begin{array}{l}\text { 13. A organização obtém ou gera, e } \\
\text { utiliza, informações de qualidade } \\
\text { relevante para suportar a } \\
\text { operação dos controles internos. }\end{array}$ & $\begin{array}{l}\text { A organização obtém ou gera, e utiliza, informações de qualidade } \\
\text { relevante para suportar a operação dos controles internos, } \\
\text { através de seu banco de dados, que suporta seu ERP, seja } \\
\text { através de benchmark ou de consultorias externas. }\end{array}$ \\
\hline $\begin{array}{l}\text { 14. A organização divulga } \\
\text { informações internamente, } \\
\text { incluindo os objetivos e } \\
\text { responsabilidades dos controles } \\
\text { internos, necessárias para } \\
\text { suportar sua operação. }\end{array}$ & $\begin{array}{l}\text { A organização divulga informações internamente, incluindo os } \\
\text { objetivos e responsabilidades dos controles internos, necessárias } \\
\text { para suportar sua operação, porém o faz de forma parcial, de } \\
\text { acordo com os agentes internos e externos e com a prática } \\
\text { verificada. }\end{array}$ \\
\hline $\begin{array}{l}\text { 15. A organização divulga } \\
\text { externamente informações } \\
\text { relacionadas a ocorrências que } \\
\text { afetem a operação dos controles } \\
\text { internos. }\end{array}$ & $\begin{array}{l}\text { A organização divulga externamente informações relacionada } \\
\text { ocorrências que afetem a operação dos controles internos, } \\
\text { não o faz de forma rotineira e nem abrangente, de acordo con } \\
\text { respondentes externos e com a prática verificada. }\end{array}$ \\
\hline
\end{tabular}

$\mathrm{Na}$ área de Informação e Comunicação, a organização gera e utiliza informações de qualidade para suportar seus controles internos, divulga informações internamente, mas precisa melhorar sua eficiência em comunicar, e divulga informações externamente, mas precisa torna-la mais frequente e abrangente.

\subsection{Avaliação de Maturidade Empresarial - Análise das Respostas aos Questionários - Parte 2}

Em relação à Avaliação de Maturidade Empresarial, o autor buscou abranger os Parâmetros Metodológicos de Oliva (2016). Nesse caso, analisando os clusters demonstrados na Figura 23, o autor elaborou perguntas que buscaram extrair dos respondentes externos e internos respostas que localizassem a organização dentro da escala proposta, o que se verifica na Tabela 02. Em itálico, as considerações do autor baseadas em seu conhecimento e experiência com a atividade de gerenciamento de risco corporativo na organização, quando aplicável. 
Tabela 02: Análise das Respostas aos Questionários - Parte 2

\begin{tabular}{|c|c|c|c|}
\hline \multicolumn{2}{|c|}{ OLIVA (2016) } & \multirow[b]{2}{*}{ QUESTÃO } & \multirow[b]{2}{*}{ AVALIAÇÃO DO AUTOR } \\
\hline $\begin{array}{l}\text { FATOR DE } \\
\text { RISCO }\end{array}$ & PARÂMETROS & & \\
\hline \multirow{4}{*}{ Organização } & $\begin{array}{l}\text { - Grau de Consciência } \\
\text { em Gerenciamento } \\
\text { de Risco Corporativo } \\
\text { - Grau de Organização } \\
\text { dos Processos } \\
\text { Relacionados a } \\
\text { Gerenciamento de } \\
\text { Risco Corporativo }\end{array}$ & $\begin{array}{l}\text { A AkzoNobel PPC é ciente da } \\
\text { necessidade de possuir uma } \\
\text { atividade estruturada de } \\
\text { Gerenciamento de Risco? }\end{array}$ & $\begin{array}{l}\text { A maioria dos respondentes internos e } \\
\text { externos percebe que sim, com algumas } \\
\text { poucas exceções tendo a percepção de } \\
\text { que a organização o faz parcialmente, e } \\
\text { dois respondentes internos com percepção } \\
\text { de que a organização não é ciente. } \\
\text { Prevalece assim a percepção de que a } \\
\text { empresa é ciente da necessidade de } \\
\text { possuir tal atividade de forma estruturada. }\end{array}$ \\
\hline & $\begin{array}{l}\text { - Grau de Consciência } \\
\text { em Gerenciamento } \\
\text { de Risco Corporativo }\end{array}$ & $\begin{array}{l}\text { A AkzoNobel PPC é ciente } \\
\text { dos ganhos advindos de } \\
\text { possuir uma estrutura eficaz } \\
\text { de Gerenciamento de Risco? }\end{array}$ & $\begin{array}{l}\text { Resposta praticamente idêntica, com a } \\
\text { percepção de que a organização é } \\
\text { totalmente ou parcialmente ciente. Dois } \\
\text { respondentes internos tem a percepção de } \\
\text { que a organização não é ciente. Prevalece } \\
\text { assim a percepção de que a empresa é } \\
\text { ciente de haver ganhos com a adoção de } \\
\text { uma estrutura para esse fim. }\end{array}$ \\
\hline & $\begin{array}{l}\text { - Grau de Consciência } \\
\text { em Gerenciamento } \\
\text { de Risco Corporativo }\end{array}$ & $\begin{array}{l}\text { A AkzoNobel PPC enxerga o } \\
\text { Gerenciamento de Risco como } \\
\text { custo ou benefício? }\end{array}$ & $\begin{array}{l}\text { A maioria das respostas traz a percepção } \\
\text { de que a organização enxerga o } \\
\text { Gerenciamento de Risco Corporativo com } \\
\text { Benefício. Um respondente interno e um } \\
\text { externo não souberam responder. }\end{array}$ \\
\hline & \begin{tabular}{l} 
- Grau de Organização \\
dos Processos \\
Relacionados a \\
Gerenciamento de \\
Risco Corporativo \\
- Grau de \\
Centralização das \\
Atividades de \\
Gerenciamento de \\
\multicolumn{2}{l}{ Risco Corporativo } \\
\end{tabular} & $\begin{array}{l}\text { A AkzoNobel PPC possui uma } \\
\text { estrutura centralizada de } \\
\text { Gerenciamento de Riscos } \\
\text { Corporativos? }\end{array}$ & $\begin{array}{l}\text { Os respondentes externos, em sua maioria, } \\
\text { não soube responder. A maioria dos } \\
\text { respondentes internos respondeu com } \\
\text { percepção negativa, o que corresponde à } \\
\text { realidade da empresa, e alguns } \\
\text { respondentes internos responderam com a } \\
\text { percepção positiva, demonstrando seu } \\
\text { desconhecimento. A organização distribui } \\
\text { essa atividade e responsabilidade entre os } \\
\text { agentes do processo nos departamentos. }\end{array}$ \\
\hline \multirow{3}{*}{ Tecnicidade } & $\begin{array}{l}\text { - Nível de Estrutura } \\
\text { Física e Conceitual } \\
\text { Estabelecida para o } \\
\text { Gerenciamento de } \\
\text { Risco Corporativo }\end{array}$ & $\begin{array}{l}\text { A AkzoNobel PPC demonstra } \\
\text { a intenção de investir em } \\
\text { melhorias de suas atividades } \\
\text { de gerenciamento de risco? }\end{array}$ & $\begin{array}{l}\text { A maioria dos respondentes externos e } \\
\text { internos tem a percepção positiva. } \\
\text { Alguns respondentes internos não } \\
\text { souberam responder, e dois tem } \\
\text { percepção negativa. A percepção da } \\
\text { maioria, portanto é positiva. }\end{array}$ \\
\hline & $\begin{array}{l}\text { - Grau de Organização } \\
\text { dos Processos } \\
\text { Relacionados a } \\
\text { Gerenciamento de } \\
\text { Risco Corporativo } \\
\text { - Nível de Estrutura } \\
\text { Física e Conceitual } \\
\text { Estabelecida para o } \\
\text { Gerenciamento de } \\
\text { Risco Corporativo }\end{array}$ & $\begin{array}{l}\text { Existe um orçamento } \\
\text { específico para atividades de } \\
\text { Gerenciamento de Risco? }\end{array}$ & $\begin{array}{l}\text { Os respondentes externos não souberam } \\
\text { responder, o que ao autor considerou } \\
\text { natural. A maioria dos respondentes } \\
\text { internos teve a percepção negativa, o } \\
\text { que corresponde à realidade da } \\
\text { empresa. O orçamento para essa } \\
\text { atividade é diluído entre os orçamentos } \\
\text { das áreas, não havendo uma rubrica } \\
\text { específica. }\end{array}$ \\
\hline & $\begin{array}{l}\text { - Grau de Organização } \\
\text { dos Processos } \\
\text { Relacionados a } \\
\text { Gerenciamento de } \\
\text { Risco Corporativo } \\
\text { - Nível de Estrutura } \\
\text { Física e Conceitual }\end{array}$ & $\begin{array}{l}\text { Os colaboradores envolvidos } \\
\text { no processo de gerenciamento } \\
\text { de risco da AkzoNobel PPC } \\
\text { possuem treinamento } \\
\text { específico para isso? }\end{array}$ & $\begin{array}{l}\text { A maioria dos respondentes externos } \\
\text { teve percepção positiva. Entre os } \\
\text { respondentes internos, pequena parte } \\
\text { não soube responder, e a maioria } \\
\text { respondeu com percepção positiva ou } \\
\text { parcial. A percepção parcial é explicável, } \\
\text { uma vez que os colaboradores, ainda }\end{array}$ \\
\hline
\end{tabular}




\begin{tabular}{|c|c|c|c|}
\hline & $\begin{array}{l}\text { Estabelecida para o } \\
\text { Gerenciamento de } \\
\text { Risco Corporativo }\end{array}$ & & $\begin{array}{l}\text { que não treinados em Gerenciamento de } \\
\text { Risco Corporativo de forma conceitual, } \\
\text { são conhecedores dos riscos inerentes } \\
\text { às suas atividades. }\end{array}$ \\
\hline & $\begin{array}{l}\text { - Nível de Estrutura } \\
\text { Física e Conceitual } \\
\text { Estabelecida para o } \\
\text { Gerenciamento de } \\
\text { Risco Corporativo }\end{array}$ & $\begin{array}{l}\text { O processo de Gerenciamento } \\
\text { de Risco da AkzoNobel PPC } \\
\text { depende de pessoas ou } \\
\text { possui um método de suporte } \\
\text { que o sustente? }\end{array}$ & $\begin{array}{l}\text { A maioria dos respondentes externos } \\
\text { respondeu com a percepção de que a } \\
\text { empresa possui um método forte que } \\
\text { sustente o processo. Os respondentes } \\
\text { internos reconhecem que há um método, } \\
\text { mas que a dependência de pessoas no } \\
\text { processo é muito forte. }\end{array}$ \\
\hline & - Nível de Utilização & $\begin{array}{l}\text { A AkzoNobel PPC possui } \\
\text { ferramenta de Gerenciamento } \\
\text { de Riscos? }\end{array}$ & $\begin{array}{l}\text { Os clientes responderam não saber. Os } \\
\text { fornecedores responderam com } \\
\text { percepção positiva. Internamente, há a } \\
\text { percepção de que existe uma ferramenta } \\
\text { que cubra parcialmente o Gerenciamento } \\
\text { de Risco Corporativo, o que corresponde } \\
\text { á realidade da empresa. }\end{array}$ \\
\hline & $\begin{array}{lr}\text { Ferramentas } & \text { de } \\
\text { Métodos } & \text { de } \\
\text { Gerenciamento } & \text { de } \\
\text { Risco Corporativo } & \end{array}$ & $\begin{array}{l}\text { A AkzoNobel PPC estabelece } \\
\text { Gerenciamento de Risco para } \\
\text { todas as suas atividades e } \\
\text { processos? }\end{array}$ & $\begin{array}{l}\text { Um dos respondentes externos teve a } \\
\text { percepção parcial, outros dois não } \\
\text { souberam responder e um último teve } \\
\text { percepção positiva. A maioria dos } \\
\text { respondentes internos teve percepção } \\
\text { negativa ou parcial. O Gerenciamento de } \\
\text { Risco Corporativo parcial corresponde à } \\
\text { realidade da organização. }\end{array}$ \\
\hline \multirow{2}{*}{ Transparência } & \begin{tabular}{lr} 
- Importância & da \\
Comunicação & Interna \\
e Externa nos & nos \\
Processos & de \\
Gerenciamento de & de \\
\multicolumn{2}{l}{ Risco Corporativo }
\end{tabular} & $\begin{array}{l}\text { Você conhece a forma como a } \\
\text { AkzoNobel PPC toma } \\
\text { decisões r sobre } \\
\text { Gerenciamento de Riscos? }\end{array}$ & $\begin{array}{l}\text { Os respondentes internos e externos } \\
\text { responderam com a percepção de } \\
\text { conhecer parcialmente ou não conhecer } \\
\text { a forma como a AkzoNobel toma } \\
\text { decisões para gerenciar seus riscos. }\end{array}$ \\
\hline & $\begin{array}{l}\text { - Importância da } \\
\text { Comunicação Interna } \\
\text { e Externa nos } \\
\text { Processos de } \\
\text { Gerenciamento de } \\
\text { Risco Corporativo } \\
\end{array}$ & $\begin{array}{l}\text { A AkzoNobel PPC comunica } \\
\text { adequadamente } \\
\text { organização qual é o seu } \\
\text { plano de Gerenciamento de } \\
\text { Risco? }\end{array}$ & $\begin{array}{l}\text { Os respondentes internos e externos } \\
\text { responderam com percepção negativa ou } \\
\text { de que a organização o faz somente } \\
\text { parcialmente. }\end{array}$ \\
\hline \multirow{3}{*}{ Envolvimento } & $\begin{array}{l}\text { - Grau de } \\
\text { Envolvimento dos } \\
\text { Colaboradores em } \\
\text { Geral nas Atividades } \\
\text { de Gerenciamento de } \\
\text { Risco Corporativo }\end{array}$ & $\begin{array}{l}\text { A AkzoNobel PPC enfrenta } \\
\text { resistência dos funcionários } \\
\text { para realizar atividades de } \\
\text { Gerenciamento de Risco? }\end{array}$ & $\begin{array}{l}\text { A percepção de um dos respondentes } \\
\text { externos foi positiva, e a dos outros foi } \\
\text { negativa ou de não saber. Internamente } \\
\text { a maioria dos respondentes ficou entre a } \\
\text { percepção negativa ou parcial. }\end{array}$ \\
\hline & \begin{tabular}{lr} 
- Utilização & de \\
Expertise & Externa \\
(Consultorias r e & e \\
Parceiros) em & seu \\
Processo & de \\
Gerenciamento de & de \\
\multicolumn{2}{l}{ Risco Corporativo } \\
\end{tabular} & $\begin{array}{l}\text { A AkzoNobel PPC contrata } \\
\text { expertises externas } \\
\text { (consultores e parceiros) para } \\
\text { fortalecer seu processo de } \\
\text { Gerenciamento de Risco? }\end{array}$ & $\begin{array}{l}\text { Os respondentes externos responderam } \\
\text { não saber. A maioria dos respondentes } \\
\text { internos respondeu com percepção } \\
\text { negativa ou não saber, mas a realidade } \\
\text { da organização é recorrer a esse tipo de } \\
\text { recurso. }\end{array}$ \\
\hline & $\begin{array}{l}\text { - Avaliação de Risco } \\
\text { Transcendente ao } \\
\text { Ambiente de Valor da } \\
\text { Companhia (Interno), } \\
\text { Incluindo o Ambiente } \\
\text { de Negócio (Externo) }\end{array}$ & $\begin{array}{l}\text { A AkzoNobel PPC avalia seus } \\
\text { riscos considerando também o } \\
\text { ambiente externo à } \\
\text { organização (ver figura Riscos } \\
\text { Empresariais no Ambiente de } \\
\text { Valor)? }\end{array}$ & $\begin{array}{l}\text { A maioria dos respondentes externos } \\
\text { sinalizou com percepção positiva. Entre } \\
\text { os internos, a maioria sinalizou com } \\
\text { percepção positiva ou parcial. A } \\
\text { realidade da organização é considerar } \\
\text { tais riscos parcialmente, uma vez que } \\
\text { não consegue abranger todos os riscos } \\
\text { externos em seus controles. }\end{array}$ \\
\hline
\end{tabular}

Fonte: autoria própria (2017) 


\subsection{Gerenciamento de Risco Corporativo e Avaliação de Maturidade Empresarial - Análise dos Dados - Conclusões}

\subsubsection{Gerenciamento de Risco Corporativo}

Para chegar às suas conclusões, aqui novamente o autor mesclou seu conhecimento da metodologia da organização com as respostas perceptivas recebidas através da aplicação do Questionário - Parte 1.

O papel da Alta Direção na atividade de gerenciamento de risco corporativo está definido, e a imagem percebida é de independência da gerência e ciência de seu papel supervisório.

Em termos de recursos, a clareza não se repete. A empresa possui um time definido de Controles Internos, mas não tem um time exclusivo de gerenciamento de risco corporativo, pois entende que tal atividade deve permear por todos os departamentos. Em relação à metodologia de Gerenciamento de Risco Corporativo, há a percepção de que a organização é bastante atenta à possibilidade de fraudes. Há também a percepção positiva de que há um robusto banco de dados suportando às atividades. Os controles internos são verificados com o rigor e a periodicidade adequadas, e as eventuais deficiências encontradas são divulgadas e corrigidas.

Quando o gerenciamento de risco corporativo é associado aos objetivos da empresa, boa parte da organização demonstra não ter conhecimento suficiente desse relacionamento.

O tratamento dos riscos externos específicos do negócio tem uma abrangência parcial, explicável pela própria natureza dos riscos, que limitam o alcance da empresa a resolvêlos, evita-los ou mitiga-los integralmente. Já os riscos internos tem um gerenciamento mais efetivo, uma vez que a organização consegue trata-los dentro de sua zona de atuação.

A comunicação, como elemento da eficácia do gerenciamento de risco corporativo, é o quesito que mais suscitou pontos de discussão. Os agentes internos e externos consideram que a organização não comunica adequadamente sua estratégia de gerenciamento de risco corporativo bem como sua estratégia traduzida em objetivos. O paradoxo é que a organização tem uma política extremamente aberta e democrática de comunicação, mas que não se reflete nesse ponto específico. 
Concluindo, e retomando os parâmetros, COSO (2013) o Ambiente de Controle da empresa está bem estabelecido e é robusto, com atividades e responsabilidades bem definidas.

A Avaliação de Riscos traz uma oportunidade de melhoria, que é aumentar a abrangência da atividade de gerenciamento de risco corporativo para todos os riscos mapeados, e não somente para os riscos identificados em Finanças e em Supply Chain, ainda que isso seja feito gradualmente.

As Atividades de Controle trazem a mesma oportunidade, que é aumentar a abrangência para todos os riscos mapeados.

Informação e Comunicação traz um modelo robusto do ponto de vista de Informação e passível de sensíveis melhorias em Comunicação, tanto interna quanto externa, especialmente na divulgação de riscos relacionados a objetivos.

\subsubsection{Avaliação de Maturidade}

Para chegar às suas conclusões, da mesma forma o autor mesclou seu conhecimento da metodologia da organização com as respostas perceptivas recebidas através da aplicação do Questionário - Parte 2.

Considerando o Fator de Risco Organização, as respostas trouxeram a percepção de que a organização é ciente da necessidade de possuir uma estrutura de gerenciamento de risco corporativo, sendo também ciente dos ganhos advindos de uma estrutura desse tipo e enxergando-a, assim, como um benefício. A organização, no entanto, não possui uma estrutura centralizada de gerenciamento de risco corporativo, preferindo com que cada agente do processo, em sua respectiva área de atuação, seja responsável pela sua parte nessa atividade.

Quanto ao Fator de Risco Tecnicidade, não há uma declaração formal da Organização quanto a investimentos em gerenciamento de risco corporativo, ainda que pareça lógico que ano a ano isso aconteça. No orçamento também não há uma rubrica especifica para essa atividade, sendo a despesa distribuída por todas as áreas. O treinamento e atuação dos colaboradores é muito mais guiado por sua expertise em suas respectivas atividades, aplicadas à ferramenta, do que por um treinamento conceitual em gerenciamento de risco corporativo. A organização possui um método específica para a atividade, mas todo o 
processo é ainda dependente de pessoas. Por fim, a cobertura do gerenciamento de risco corporativo para as atividades da organização ainda é parcial.

No tocante ao Fator de Risco Transparência, ainda que do ponto de vista ético e financeiro a organização goze de excelente reputação no mercado, seus esforços em comunicação direcionada a gerenciamento de risco corporativo foram reconhecidos como insuficientes. Por fim, o Fator de Risco Envolvimento traz a percepção de que há relativa participação dos funcionários quanto às atividades de gerenciamento de risco corporativo, sendo tais atividades orientadas, entretanto, para sua participação ativa (motivo pelo qual a empresa não estabeleceu um departamento), a organização efetivamente recorre a expertise externa se e quando necessário, e não é capaz de gerenciar seus riscos externos na totalidade.

Dessa forma, voltando ao quadro proposto por Oliva (2016), podemos considerar a organização posicionada assim quanto à sua Maturidade, conforme Figura 23:

Figura 23: Avaliação de Maturidade da Organização conforme Oliva (2016)

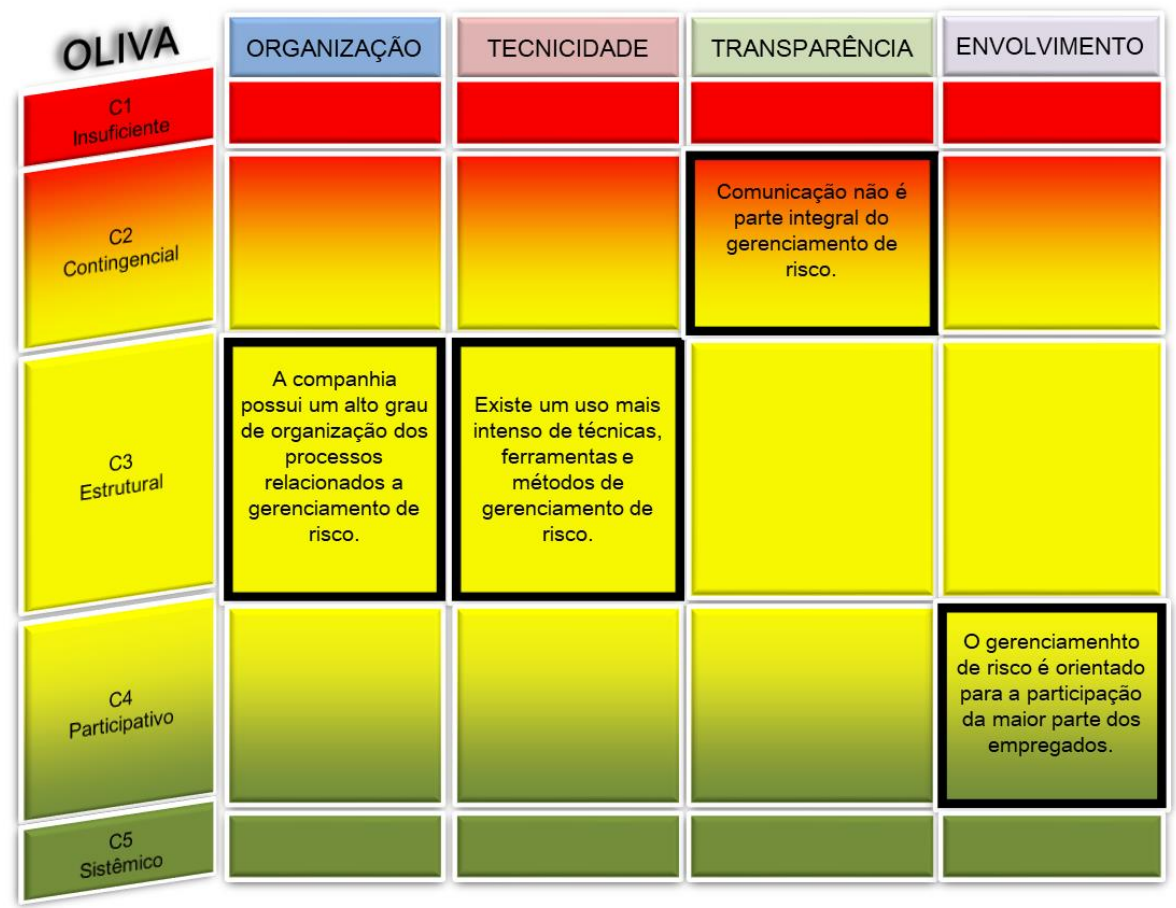

Fonte: adaptado de Oliva (2016). 
Conforme a parametrização verificada em Oliva (2016), o autor avaliou a maturidade empresarial da organização como Estrutural (nível C3) para os fatores Organização e Tecnicidade, Contingencial (nível C2) para o fator Transparência e Participativo (nível C4) para o fator Envolvimento. 


\section{FIGURA DA ORGANIZAÇÃO}

\begin{tabular}{|c|c|c|}
\hline \multicolumn{2}{|l|}{ RESUMO \& ABSTRACT } & $\begin{array}{c}\text { SUMÁRIO } \\
\text { LISTADEFIGURASE TABELAS }\end{array}$ \\
\hline $\begin{array}{l}\text { 1.INTRODUÇÃo } \\
\text { 1.1 - Definição da Situação-Problema } \\
\text { 1.2 - Objetivos } \\
\text { 1.3 - Resultados Esperados }\end{array}$ & \multicolumn{2}{|c|}{$\begin{array}{l}1.4 \text { - Delimitações } \\
1.5 \text { - Justificativas e Contribuições }\end{array}$} \\
\hline $\begin{array}{l}\text { 2. REVSÃOTEÓRICA } \\
\text { 2.1 - Análise e Caracterização do Risco } \\
\text { 2.2 - Avaliação do Risco Corporativo } \\
\text { 2.3 - Gerenciamento de Risco Corporativo } \\
\text { 2.3.1 - Abordagem COSO } \\
\text { 2.3.2 - Abordagem ABNT }\end{array}$ & $\begin{array}{l}\text { 2.3.3 - Abordagem Nohara et al } \\
\text { 2.3.4 - Comparativo das Abordagens COSO x ABNT } \\
\text { ISO x Nohara et al. e Justificativa } \\
\text { 2.4 - Avaliação de Maturidade em Gerenciamento de } \\
\text { Risco Corporativo } \\
\text { 2.4.1 - Abordagem de Poltronieri }\end{array}$ & $\begin{array}{l}\text { 2.4.2 - Abordagem de Oliva } \\
\text { 2.4.3 - Abordagem de Hillson } \\
\text { 2.4.4 - Comparação das Abordagens Poltronieri x Oliva } \\
\text { x Hillson e Justificativa }\end{array}$ \\
\hline \multicolumn{3}{|c|}{$\begin{array}{c}\text { 3. CONTEXTUA IZAÇĀO } \\
3.1 \text { - A AkzoNobel no Brasil } \\
\text { 3.2 - Cadeia de Valor da Industria de Celulose } \\
\text { 3.2.1 - Fatores de Risco para Monitoramento na Cadeia de Valor da Celulose } \\
3.3 \text { - O Negócio de Celulose no Brasil }\end{array}$} \\
\hline \multicolumn{3}{|c|}{$\begin{array}{c}\text { 4. MÉTODOSE TÉCNICAS } \\
\text { 4.1 - Justificativa para a Escolha pelo Método de Pesquisa Qualitativa } \\
4.2 \text { - Validação de Pesquisa }\end{array}$} \\
\hline $\begin{array}{l}\text { 5-ANÁLISEDOSDADOS } \\
\text { 5.1 - Gerenciamento do Risco Corporativo e Avaliação } \\
\text { de Maturidade na AkzoNobel } \\
\text { 5.1.1 - Gerenciamento de Risco Corporativo na } \\
\text { AkzoNobel } \\
\text { 5.1.1.1 - Avaliação de Risco } \\
\text { 5.1.1.2 - Plano de Ação de Mitigação de Riscos } \\
\text { 5.1.1.3 - Análise de Portfólio } \\
\text { 5.1.2 - Principais Tipos de Risco aos quais a }\end{array}$ & $\begin{array}{l}\text { AkzoNobel Está Exposta } \\
5.2 \text { - Gerenciamento de Risco Corporativo - Análise d } \\
\text { Respostas } \\
\text { 5.2.1 - Gerenciamento de Risco Corporativo - } \\
\text { Comparativo com a parametrização COSO (2013) } \\
\text { 5.2.1.1 - Ambiente de Controle } \\
\text { 5.2.1.2 - Avaliação de Riscos } \\
\text { 5.2.1.3 - Atividades de Controle } \\
\text { 5.2.1.4 - Informação e Comunicação }\end{array}$ & $\begin{array}{l}\text { 5.3 - Avaliação de Maturidade Empresarial - Análise } \\
\text { e das Respostas } \\
5.4 \text { - Gerenciamento de Risco Corporativo e Avaliação } \\
\text { de Maturidade Empresarial - Análise dos Dados - } \\
\text { Conclusões } \\
\text { 5.4.1 - Gerenciamento de Risco Corporativo } \\
\text { 5.4.2 - Avaliação de Maturidade }\end{array}$ \\
\hline \multicolumn{3}{|c|}{ 6. FIGURADAORGANZAÇÃO } \\
\hline \multirow[t]{2}{*}{$\begin{array}{l}\text { 7.1 - Objetivos } \\
\text { 7.1.1 - Objetivo Geral } \\
\text { 7.1.2 - Objetivos Específicos } \\
\text { 7.2 - Implicações Gerenciais }\end{array}$} & \multicolumn{2}{|l|}{$\begin{array}{l}7.3 \text { - Processo Metodológico } \\
7.4 \text { - Delimitações } \\
7.5 \text { - Aplicações Futuras } \\
7.6 \text { - Considerações Finais }\end{array}$} \\
\hline & $\begin{array}{l}\text { REFERÉNCIAS } \\
\text { CRONOGRAMA } \\
\text { GLOSSÁRO }\end{array}$ & \\
\hline \multirow[t]{2}{*}{$\begin{array}{l}\qquad \text { ANEXOS } \\
\text { 01. Figura llustrativa do Conceito de llha Química } \\
\text { 02. COSO Integrated Framework Principles }\end{array}$} & \multicolumn{2}{|c|}{$\begin{array}{l}\text { 03. Modelo de Hillson } \\
\text { 04. Enterprise Risks in the Environment of Value }\end{array}$} \\
\hline & \multicolumn{2}{|l|}{$\begin{array}{l}\text { APÉNDICESO3 } \\
\text { 01. Questionário } \\
\text { 02. Respostas Agrupadas - Parte } 1 \\
\text { 03. Respostas Agrupadas - Parte } 2\end{array}$} \\
\hline
\end{tabular}




\section{CONCLUSÃO}

"A palavra "risco" deriva do italiano antigo risicare, que significa "ousar". Neste sentido, o risco é uma opção, e não um destino. É das ações que ousamos tomar, que dependem de nosso grau de liberdade de opção, que a história do risco trata. E essa história ajuda a definir o que é um ser humano." (Bernstein,1996).

A Revisão Teórica permitiu o acesso a importante literatura e a várias metodologias nessa área, basicamente dividida entre Gerenciamento de Risco Corporativo e Avaliação de Maturidade Empresarial. Em Gerenciamento de Risco Corporativo o foco principal foi COSO (2013), ABNT ISO (2009) e Nohara et al. (2005), tendo autor optado por COSO (2013) para suas análises. Em Avaliação de Maturidade Empresarial o foco foi Poltronieri (2014), Oliva (2016) e Hillson (1997), tendo o autor optado pela abordagem de Oliva (2016) como base para suas análises. Os dois assuntos foram abordados, pois ao lado do Gerenciamento de Risco Corporativo caminha a necessidade de Avaliação da Maturidade Empresarial no processo de gerenciamento de risco corporativo adotado. Ela qualifica metodologicamente em que posição a empresa se encontra em seu processo de gerenciamento de risco corporativo, permitindo uma evolução que torne cada vez mais eficiente o tratamento e a mitigação das ameaças ao negócio.

No contexto abordado, a situação problema no geral é a existência do risco em si, agravado pela não adoção de um método adequado para seu gerenciamento. Derivando a situação problema para o foco particular, traz para o foco a AkzoNobel em seu negocio de Celulose no Brasil, que embora possua gerenciamento de risco corporativo, não o ancora numa metodologia específica, e não agrega à atividade um modelo de avaliação de maturidade empresarial. Os objetivos do estudo foram propostos com o mesmo foco.

\subsection{Objetivos}

\subsubsection{Objetivo Geral}

O objetivo geral desse estudo foi analisar o gerenciamento de risco corporativo praticado na empresa AkzoNobel, em seu negócio de Celulose no Brasil. O que se verificou com a aplicação do questionário, aliada à experiência do autor na organização, é que a Alta Direção, no tocante a gerenciamento de risco corporativo, tem seu papel definido, e age independentemente da gerência em seu papel supervisório. Os recursos não são 
exclusivos da atividade, estando parcialmente alocados nos departamentos envolvidos. Há um foco maior em fraudes e um robusto banco de dados dá suporte adequado às atividades de Controles Internos. A visão estratégica não é suficientemente permeada, uma vez que boa parte da organização desconhece o relacionamento entre os riscos e o alcance dos objetivos da organização. A comunicação também não está no nível ideal, mesmo que a organização tenha uma política de extrema transparência empresarial. Utilizando COSO (2013) como parâmetro de comparação, foi possível chegar à seguinte análise: A atividade de gerenciamento de risco corporativo possui um bom ambiente de controles internos, mas precisa aumentar seu leque de ações para áreas que estejam fora de Finanças e do Supply Chain. O mesmo aumento de abrangência deve ser aplicado às suas atividades de controle. Embora o modelo de controle de informações possa ser mantido, considerando sua robustez atual, a estratégia de comunicação carece de sensível melhoria, visando tornar mais efetiva a divulgação das atividades de gerenciamento de risco corporativo praticadas, assim como garantir uma melhor divulgação do relacionamento entre riscos e objetivos estratégicos.

\subsubsection{Objetivos Específicos}

Um objetivo específico do estudo foi identificar os principais riscos corporativos na cadeia de valor, com foco em Supply Chain. O estudo transitou do ambiente interno ao ambiente externo à companhia, considerando que o produto está no centro de uma cadeia produtiva. O negócio tem grandes dimensões em termos de produção e faturamento, mas maneja recursos naturais, estando sujeito a riscos peculiares. A madeira, como matériaprima, é reflorestada e geneticamente modificada, mas fica sujeita aos humores naturais. Seu plantio demanda extensas áreas, com terras a baixo custo, o que quase sempre as localiza em locais remotos. Alguns desses locais obrigam ao trato com minorias silvícolas e o cuidado com ambientes sob proteção ecológica. A energia é outro item de importância fundamental ao negócio, pois é demandada em grandes quantidades, estando sujeita a riscos legislatórios e de disponibilidade, além da demanda política que por vezes orienta o setor. Os demais riscos são mais comuns, pois se referem a mão-de-obra, produtos químicos e custos indiretos. 
O outro objetivo específico do estudo foi avaliar o nível de maturidade da empresa no gerenciamento de risco corporativo. A análise das respostas ao questionário, juntamente com a experiência do autor, foram a base da avaliação. Nesse caso, o autor optou pelo modelo de Oliva (2016) e, aplicando seus parâmetros chegou à avaliação seguinte: Quanto ao fator Organização, existe a ciência da necessidade de possuir uma estrutura para gerenciamento de risco corporativo, ainda que não formalizada em um departamento específico, assim como o entendimento de sua existência como benefício, e não custo. Quanto ao fator Tecnicidade, não há uma rubrica específica para investimentos nessa área, mas eles ocorrem de forma distribuída. Também não há, de forma abrangente, treinamentos específicos na área de gerenciamento de risco corporativo. Embora haja um método específico, todo o processo ainda é muito dependente de pessoas. Por fim, a atividade ainda é focada em áreas como Finanças e Supply Chain. Quanto à Transparência, os esforços em comunicação ainda são vistos como insuficientes pelo público interno, não havendo distribuição da informação de forma satisfatória. Por fim, o fator Envolvimento trouxe a percepção de relativa participação dos funcionários como um todo nessa atividade, ainda que a orientação organizacional esteja direcionada à participação massiva, atestou que a organização recorre a expertise externa, e que fica exposta a riscos de origem externa sem poder gerenciá-los em sua totalidade.

Assim, segundo a abordagem de Oliva (2016), o autor avaliou a maturidade empresarial da organização como Estrutural (nível C3) para os fatores Organização e Tecnicidade, Contingencial (nível C2) para o fator Transparência e Participativo (nível C4) para o fator Envolvimento. O autor, com essa base, indica como pontos de melhoria: estudar a formação de um departamento de gerenciamento de risco corporativo, organizar seus investimentos nessa área sob rubrica específica, adotar método mais robusto para suporte à atividade, investir em treinamentos específicos e investir em uma linha mais efetiva de comunicação.

O autor entende assim ter alcançado os objetivos propostos, que eram a análise do Gerenciamento de Risco Corporativo na organização e a Avaliação do Grau de Maturidade da organização em Gerenciamento de Risco Corporativo. 


\subsection{Implicações Gerenciais}

Supply Chain, foi o foco desse trabalho considerando que o autor tem praticamente toda sua experiência profissional vivida em meio às suas diversas atividades. Durante sua pesquisa, o autor encontrou vasta literatura em gerenciamento de risco corporativo nas áreas de Projetos e Finanças, mas, comparativamente, uma disponibilidade bem menor em Supply Chain. Em sua mais recente experiência o autor tem colaborado com a AkzoNobel em seu negócio de Celulose, e também nessa área existe literatura restrita sobre gerenciamento de risco corporativo. Tais restrições animaram o autor a contribuir com a literatura da área através de sua pesquisa. Conceitualmente, o autor também entende que o gerenciamento de risco corporativo é de suma importância para a perenidade do negócio e da própria organização, mas que como parte de sua composição são muito importantes uma robusta ferramenta de suporte e um método estabelecido que preveja a manutenção cíclica de toda a atividade, configurando o gerenciamento de risco corporativo como um processo vivo. Nesse contexto inclui-se também a avaliação da maturidade empresarial.

A organização analisada não possui gerenciamento de risco corporativo ancorado em método robusto nem possui em seus processos a avaliação da maturidade empresarial, e insere-se no negócio de Celulose, que é expressivo na conjuntura brasileira e global, tanto em cifras quanto em exposição a riscos corporativos. Evidentemente, por se tratar de uma grande e sólida multinacional, tem ciência de seu ambiente de valor, mas o autor contribui com suas sugestões visando melhoria nesse processo.

A organização e o negócio de Celulose em si são expostos a riscos comuns e outros bastante específicos, intrinsecamente relacionados à atividade. O gerenciamento de risco corporativo precisa ser sensível a tais características, especialmente se considerarmos os possíveis impactos ambientais que, hoje, são razão de atenção de toda a sociedade.

\subsection{Processo Metodológico}

O autor elaborou questionários que foram aplicados aos stakeholders relevantes, que contribuíram com respostas que refletiram seus olhares em suas áreas de atuação, dando retornos que possibilitaram uma análise qualitativa que permitiu ao autor chegar às suas conclusões. Uma delas é que a teoria visitada tem pouca disponibilidade de material a 
respeito de riscos específicos da cadeia de celulose. Dessa forma, esse trabalho reuniu informações sobre o assunto que poderão enriquecer à literatura. $\mathrm{Na}$ área de Gerenciamento de Risco Corporativo, o autor contribuiu com a comparação entre os parâmetros COSO (2013), ABNT ISO (2009) e Nohara et al. (2005), e, posteriormente, com o comparativo entre as respostas dadas aos questionários e a abordagem COSO (2013). Na área de Avaliação de Maturidade Empresarial, contribuiu com a comparação entre as abordagens de Poltronieri (2014), Oliva (2016) e Hillson (1997) e, posteriormente, com o comparativo entre as respostas dadas aos questionários e a abordagem de Oliva (2016).

\subsection{Delimitações}

A pesquisa teve um restrito número de respondentes, e essa limitação naturalmente conduziu a uma pesquisa qualitativa. É importante destacar que a organização posicionase como uma das maiores indústrias químicas do mundo, e os dados da amostra colhida não podem ser generalizados para toda a empresa.

Pela própria natureza da exploração da pesquisa, as respostas são percepções dos respondentes acerca da organização e de seus riscos. O autor buscou, para minimizar esse efeito, aplicar questões que pedissem respostas diretas, tomando cuidado, ao mesmo tempo, para não conduzi-las.

\subsection{Aplicações Futuras}

É possível sugerir uma aplicação de pesquisa mais ampla dentro da organização, incluindo outros países nos quais a empresa atua e abranger outros níveis organizacionais além da Gerência. Para aprofundar a pesquisa qualitativa, podem ser também incluídas entrevistas pessoais, de modo a extrair mais informações através desse modo de interação. Também é possível estudar, com os mesmos objetivos, todas as organizações da cadeia produtiva da fibra de celulose no Brasil.

$\mathrm{Na}$ área de Avaliação de Maturidade Empresarial, pesquisar com mais profundidade obras direcionadas a negócios e projetos, como Craig-Jones (2007) ou o material disponibilizado pela NASCIO (2009), a começar pelo documento Data Governance Part II: Maturity Models - A Path to Progress, que discorre sobre riscos no gerenciamento de dados. 
Ainda, pesquisar o material disponibilizado pelo SEI (Software Engineering Institute), órgão da Carnegie Mellon University (1993), sobre o CMM (Capability Maturity Model), utilizando-o de modo a enriquecer as abordagens realizadas nesse estudo.

Também como sugestão de estudo complementar pode ocorrer uma abordagem da Teoria da Agência, partindo do artigo de Jensen e Meckling (1976), uma vez que o os agentes podem exercer preponderante papel no gerenciamento de risco corporativo, abrindo possibilidades de estudos específicos.

Como aplicação, futuramente pode-se desenvolver uma metodologia completa em forma de produto, abrangendo facilidades para Gerenciamento de Risco Corporativo e Avaliação de Maturidade Empresarial, de forma sistematizada e com gestão organizada do conhecimento, implementando-o através de prestação de consultoria.

\subsection{Considerações Finais}

Como considerações finais ficam o desejo e a disponibilidade de aplicar o estudo à organização, a expectativa de que esse estudo forneça material para o mercado e para outros mestrandos e a profunda gratidão pelo aprendizado obtido na elaboração do trabalho. 


\section{REFERÊNCIAS}

ABNT - ASSOCIAÇÃO BASILEIRA DE NORMAS TÉCNICAS. (2009). ISO:31.000. Gestão de Riscos - Princípios e Diretrizes (pp. 1-32). Rio de Janeiro. Editora ABNT, 2009. p. 1-32

AKZONOBEL. GLOBAL. How We Are Organized. Disponível em: <https://www.akzonobel.com/about-us/how-we-are-organized>. Acesso em: 05 out. 2016

AKZONOBEL. GLOBAL. Risk Mitigation Plan. Arquivo em Power Point. Acesso em: 17 out. 2016

BACHMANN, D. L. Benchmarking Energético na Indústria de Celulose e Papel. 2009. Disponível em: <http://www.bachmann.com.br/website/documents/Energiajul09.pdf>. Acesso em: 05 set. 2016.

BERNSTEIN, P. Desafio aos Deuses: A Fascinante História do Risco, $3^{a}$ edição, p. 8. Editora Campus, Rio de Janeiro, 1996.

BM\&F BOVESPA. Política de Gestão de Riscos Corporativos. [s.I.] BM\&F BOVESPA, 2015.

COOPER, R., EDGETT, S. \& KLEINSCHMIDT, E. New Product Portfolio Management:

Practices and Performance. Journal of Product Innovation Management, 16, p. 333, 1999.

COSO - Gerenciamento De Riscos Corporativos - Estrutura Integrada: Sumário Executivo Estrutura. [S.I.: $\quad$ s.n.], 2007. 141 p. Disponível em: <http://www.coso.org/documents/COSO_ERM_ExecutiveSummary_Portuguese.pdf $>$. Acesso em: 29 set. 2016.

COSO (Committe of Sponsoring Organizations) of the Treadway Comission. Controle Interno - Estrutura Integrada. . [S.I.]: Instituto de Auditores Internos do Brasil e PWC, 2013. Disponível em: <http://www.iiabrasil.org.br/new/2013/downs/coso/COSO_ICIF_2013_Sumario_Executivo. pdf>. Acesso em: 22 mai. 2017. 
CRAIG-JONES, C. Evolving the Maturity Level of Your Project Management Office (PMO). White Paper - Series 2 of 4. [S.L.]. CA Clarity PM, 2007.

CREDIT SUISSE. Autores: Ferrão, I.; Fonseca, L.; Teixeira, N.; Vilela, L. Brasil: Cenário Melhor, Mas Ainda Incerto Para 2018 e 2019. São Paulo: Banco de Investimentos Credit Suisse (Brasil) S.A., pp 208, 213. 2017.

CUENCA, L. et al. Structural Elements of Coordination Mechanisms in Collaborative Planning Processes and Their Assessment Through Maturity models: Application to a Ceramic Tile Company. Computers in Industry, v. 64, n. 8, p. 898-911, out. 2013.

DELOITTE. (2005). Estudo da Deloitte Identifica os 29 "Destruidores de Valor" das Maiores Empresas do Mundo (pp. 1-8). São Paulo - SP. Disponível em: http://www.ebah.com.br/content/ABAAAe-A4Al/deloitte-pesquisa-destruidores-valor. Acesso em: 12 Jan. 2018.

ECONOINFO. (2017). Fatores de Risco de Suzano Papel e Celulose. Disponível em: http://www.econoinfo.com.br/governanca-corporativa/fatores-de-risco?codigoCVM=13986. Acesso em 23 Ago.2017

EPE - Empresa de Pesquisa Energética. Consumo Mensal de Energia Elétrica por Classe (Regiões e Subsistemas) - 2004-2016. $2016 . \quad$ Disponível em: <http://www.epe.gov.br/mercado/Paginas/Consumomensaldeenergiael\%C3\%A9tricaporclasse(regi \%C3\%B5esesubsistemas)\%E2\%80\%932011-2012.aspx>. Acesso em: 05 set. 2016.

EXAME, 2011. Melhores \& Maiores: As1.000 Maiores Empresas do Brasil. Revista Exame, Edição Especial, São Paulo. 2011.

FERRO, D.S. Gestão de Riscos Corporativos: Um Estudo Multicaso Sobre Seus Métodos e Técnicas. 2015. 119 f. Dissertação de Mestrado (Programa de Pós-Graduação em Administração - Mestrado em Administração) - Faculdade de Economia, Administração e Contabilidade (FEA), UNIVERSIDADE DE SÃO PAULO (USP), São Paulo - SP. 
HAIR, JR., J. F., BLACK, W.C., BABIN, B. J., ANDERSON, R.E. Multivariate Data Analysis. $7^{a}$. Ed. NEW JERSEY: PEARSON PRENTICE HALL, 2009. $761 \mathrm{p}$.

HILLSON, D. A. (1997). Towards a Risk Maturity Model. The International Journal Of Project \& Business Risk Management, Vol 1. N ${ }^{\circ} 1,35-45$.

IBÁ - INSTITUTO BRASILEIRO DE ÁRVORES - Cenários Ibá - Estatísticas da Indústria Brasileira de Árvores - Janeiro de 2018. Brasília: Indústria Brasileira de Árvores, 2018. Disponível em: <http://iba.org/images/shared/Cenarios/44_PDF_cenarios.pdf>. Acesso em: 04 maio 2018.

IBGC - INSTITUTO BRASILEIRO DE GOVERNANÇA CORPORATIVA. Guia de Orientação para o Gerenciamento de Riscos Corporativos. São Paulo, 2007. (Série de Cadernos de Governança Corporativa, 3).

IBGC - INSTITUTO BRASILEIRO DE GOVERNANÇA CORPORATIVA. Gerenciamento de Riscos Corporativos: Evolução em Governança e Estratégia. (Série de Cadernos de Governança Corporativa, 19). São Paulo, 2017.

JENSEN, M.; MECKLING, W. (1976) Theory of the Firm: Managerial Behavior, Agency Costs, and Ownership Structure. Journal of Financial Economics, 3, 305-360.

NASCIO (National Association of State Chief Information Officers). Data Governance Part II: Maturity Models - A Path to Progress. Data Governance. Lexington: NASCIO, 2009. Disponível em: $\quad$ https://www.nascio.org/Publications/ArtMID/485/ArticleID/190/Data-Governance-Part-IIMaturity-Models-\%E2\%80\%93-A-Path-to-Progress>. Acesso em: 7 maio. 2018.

NOHARA, J. J.; ACEVEDO, C. R.; VILA, A. R. Aplicação da Gestão do Conhecimento em Processos de Gerenciamento de Risco. In: Encontro Nac. de Eng. De Produção, XXV. Porto Alegre, 2005, p. 2641-2648.

OLIVA, F.L. Knowledge Management Barriers, Practices and Maturity Model. Journal of Knowledge Management, 18 (6), 1053-1074. doi.org/10.1108/JKM-03-2014-0080. USA. 2014. 
OLIVA, F. L. A Maturity Model for Enterprise Risk Management. Int. Journal Production Economics. Número 173, pp 66-79. England. 2016.

OLIVA, F. L.; DAMASCENO, M. C. S. F.; TEIXEIRA, H. J.; GRISI, C. C. H.; FISCHMANN, A. A.; SANTOS, S. A. Risks and Strategies in a Brazilian Innovation - Flexfuel Technology. Journal of Manufacturing Technology Management, Vol. 25, Issue 6, 2014, p. 916 - 930. USA.

OLIVEIRA, M. F. (Org.). Metodologia Científica: Um Manual Para a Realização de Pesquisas em Administração. 2011. Universidade Federal de Goiás. Catalão - GO. 73 p. Disponível em: <https://adm.catalao.ufg.br/up/567/o/Manual_de_metodologia_cientifica_-_Prof_Maxwell.pdf>. Acesso em: 06 fev. 2018.

Paper Mart Magazine. Brazil Green Signals Commercial Use of GM Eucalyptus. Disponível em: <http://papermart.in/2015/07/29/brazil-green-signals-commercial-use-of-gm-eucalyptus/>. Acesso em: 12 jul. 2016.

POLTRONIERI, C. F. Avaliação do Grau de Maturidade dos Sistemas de Gestão Integrados (SGI). 2014. 118 p. Dissertação (Mestre em Engenharia de Produção ) - Escola de Engenharia de São Carlos, Universidade de São Paulo (USP), São Carlos - SP.

PROJECT MANAGEMENT INSTITUTE. Um Guia Do Conhecimento Em Gerenciamento De Projetos (Guia PMBOK), Sexta Edição. Project Management Institute. Pensilvânia. P.745. 2014.

ROVAI, R. L. Modelo Estruturado para Gestão de Riscos em Projetos: Estudo de Múltiplos Casos. 2005. 364 p. Tese (Doutor em Engenharia de Produção ) - Escola Politécnica da Universidade de São Paulo (USP), São Paulo - SP.

SEI (Software Engineering Institute) team: PAULK, M. C.; WEBER, C. V.; GARCIA, S. M.; CHRISSIS, M.B.; BUSH, M. Key Practices of the Capability Maturity Model SM, Version 1.1. Pittsburgh: Software Engineering Institute - Carnegie Mellon University, 1993. Disponível em: <https://resources.sei.cmu.edu/asset_files/TechnicalReport/1993_005_001_16214.pdf>. Acesso em: 7 mai. 2018. 
SILVA, C. L.; KOPITTKE, B. H. Simulações e Cenários a Partir da Cadeia de Valor: Uma Aplicação na Indústria de Celulose. REVISTA DA FAE, CURITIBA - PR, v. 5, n. 1, p. 43-59, jan/abr. 2002.

WILLIANS, R.; BOUDEWIJN B.; BARRIE D.; VAN DER WIELE, T.; VAN IWAARDEN, J.; SMITH, M.; VISSE, R. Quality and Risk Management: What Are the Key Issues ?. The TQM Magazine, Vol. 18 No. 1, pp. 67-86, 2006. 
CRONOGRAMA

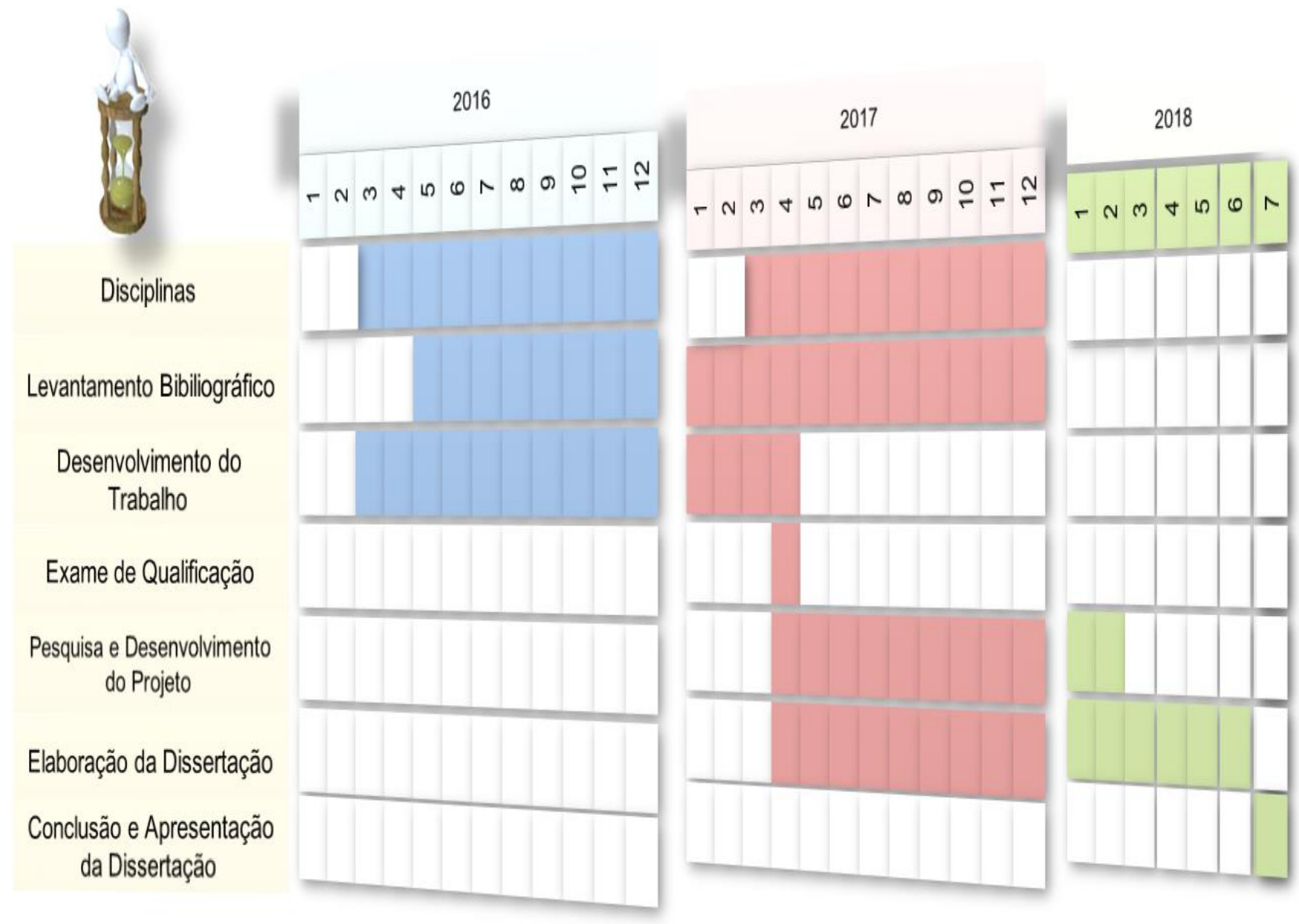




\section{GLOSSÁRIO}

\begin{tabular}{|c|c|}
\hline $\begin{array}{l}\text { À montante e à } \\
\text { jusante }\end{array}$ & $\begin{array}{l}\text { Jusante é o lado para o qual se dirige a corrente de água de um rio. Montante é a } \\
\text { nascente de um rio. A expressão "à montante e à jusante" significa antes } \\
\text { (montante) e depois (jusante) de uma determinada data ou ponto de um fluxo de } \\
\text { processo. }\end{array}$ \\
\hline Benchmark & $\begin{array}{l}\text { Um padrão ou referência, que servirá de modelo ou estrutura contra os quais } \\
\text { processos ou produtos podem ser comparados ou avaliados. }\end{array}$ \\
\hline Commodities & $\begin{array}{l}\text { Transações comerciais de produtos de origem primária na bolsa de valores, para } \\
\text { se referir a produtos de qualidade e características uniformes, que não são } \\
\text { diferenciados de acordo com quem os produziu ou de sua origem, sendo seu } \\
\text { preço uniformemente determinado pela oferta e procura internacional (Wikipédia, } \\
2016 \text { ). }\end{array}$ \\
\hline Compliance. & $\begin{array}{l}\text { Obediência a uma ordem, norma ou requisito, normalmente aplicada às áreas de } \\
\text { negócio numa organização industrial. }\end{array}$ \\
\hline $\begin{array}{l}\text { COSO (Comitte } \\
\text { of Sponsoring } \\
\text { Organization).... }\end{array}$ & $\begin{array}{l}\text { Comitê das Organizações Patrocinadoras da Comissão Treadway - Iniciativa } \\
\text { conjunta de cinco organizações do setor privado dedicada a prover o pensamento } \\
\text { líder através do desenvolvimento de estruturas e diretrizes no gerenciamento de } \\
\text { riscos empresariais, controles internos e dissuasões de fraudes. As organizações } \\
\text { são: } \\
\text { American Accounting Association; } \\
\text { AICPA - American Institute of CPAs (Certified Public Accountants) } \\
\text { FEI - Financial Executives International } \\
\text { IMA - The Association of Accountants and Financial Professionals in Business } \\
\text { IIA - Institute of Internal Auditors }\end{array}$ \\
\hline $\begin{array}{l}\text { Inbound e } \\
\text { Outbound } \\
\text { (Logística) }\end{array}$ & $\begin{array}{l}\text { O termo Inbound é aplicado à Logística de entrada em Supply Chain. De modo } \\
\text { simplificado, é a entrada de todas as compras realizadas para a cadeia na } \\
\text { modalidade } F O B \text {, ou o controle da entrega das aquisições na modalidade C\&F. O } \\
\text { termo Outbound é aplicado à Logística de saída, ou seja, a entrega de todas as } \\
\text { Vendas na modalidade C\&F e o controle da chegada no cliente de todas as } \\
\text { Vendas na modalidade } F O B \text {. }\end{array}$ \\
\hline IT & Information Technology - Tecnologia da Informação \\
\hline
\end{tabular}




\begin{tabular}{|c|c|}
\hline$I M$ & Information Management - Gerenciamento da Informação \\
\hline $\begin{array}{l}\text { Morgan Stanley } \\
\text { Capital } \\
\text { International } \\
\text { (MSCl) }\end{array}$ & $\begin{array}{l}\text { O MSCl provê ferramentas para suporte de decisões de investimentos para } \\
\text { instituições ao redor de todo o mundo. Os produtos incluem índices, análise de } \\
\text { portfólios de risco e análise de performances empresariais. }\end{array}$ \\
\hline NASCIO & $\begin{array}{l}\text { National Association of State Chief Information Officers (Associação Nacional dos } \\
\text { Chief Information Officers Estaduais). Entidade não lucrativa representando os } \\
\text { ClOs estaduais, executivos e gerentes dos estados, territórios e do distrito de } \\
\text { Columbia. Os membros principais são altos funcionários do governo estadual, } \\
\text { que têm responsabilidade em nível executivo e estadual pela liderança em } \\
\text { tecnologia da informação. Funcionários estaduais envolvidos no gerenciamento } \\
\text { de tecnologia da informação em nível de agência podem participar como } \\
\text { membros associados. Representantes de governos federais, municipais, } \\
\text { internacionais e organizações sem fins lucrativos também podem participar como } \\
\text { membros. Empresas do setor privado participam como membros corporativos e } \\
\text { participam do Conselho de Liderança Corporativa. A NASCIO fornece aos CIOs } \\
\text { estaduais e aos membros do estado, produtos e serviços projetados para apoiar o } \\
\text { papel desafiador do ClO estadual, estimular a troca de informações e promover a } \\
\text { adoção das melhores práticas e inovações de TI. }\end{array}$ \\
\hline Overhead & $\begin{array}{l}\text { Custo contido na performance de uma operação, relacionado a setores de } \\
\text { suporte. No caso da indústria, pode-se citar, dentre outros: Engenharia, } \\
\text { Operações, Administração, Compras, Segurança do Trabalho. }\end{array}$ \\
\hline Pipeline & $\begin{array}{l}\text { Tubulação longa, subterrânea, submersa ou aérea, destinada a conduzir óleos, } \\
\text { gases e líquidos a longas distâncias ou, modernamente, entre propriedades } \\
\text { vizinhas, como fábricas em condomínios industriais. }\end{array}$ \\
\hline Stakeholders & Patrocinadores, incentivadores, facilitadores. \\
\hline Tank Farm & $\begin{array}{l}\text { Área onde se instalam diversos tanques destinados a estocagem, para } \\
\text { fornecimento de materiais via pipeline a áreas circunvizinhas. }\end{array}$ \\
\hline Template & $\begin{array}{l}\text { Padrão para um processo. Se for uma peça, serve como modelo ou gabarito. Se } \\
\text { for um formulário, serve para uniformizar a coleta e organização de dados. }\end{array}$ \\
\hline Time Fence & so de tempo. \\
\hline
\end{tabular}




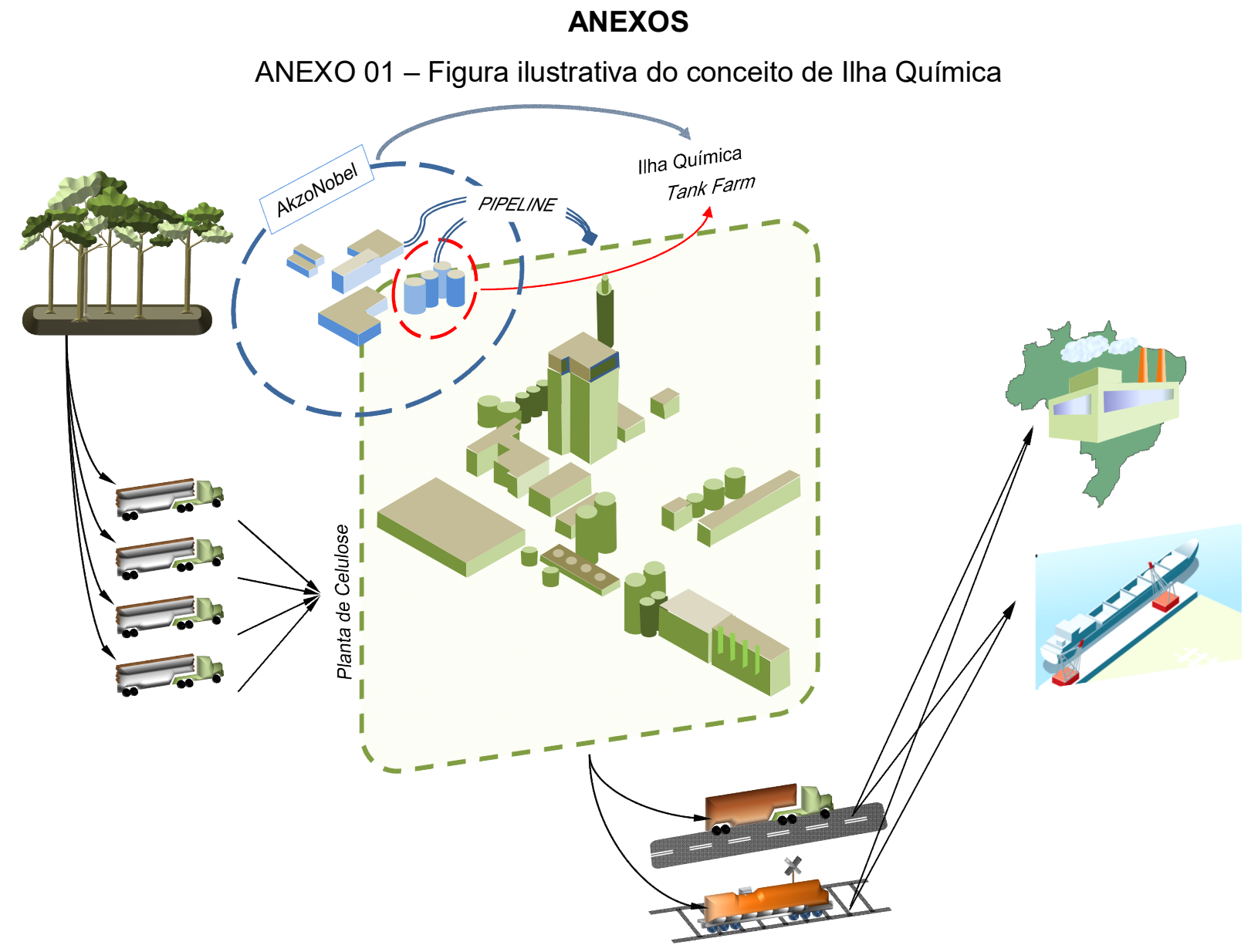

Fonte: adaptado de material da AkzoNobel (2017)

O processo de produção da celulose está diagramado na Figura 17. O Anexo 01 demonstra o conceito de llha Química, ou seja, a AkzoNobel insere sua planta produtiva dentro das instalações do cliente, produzindo o branqueador de celulose e entregando-o via pipeline, e presta-lhe o serviço de tank farm, fornecendo diversos produtos químicos em várias etapas do processo, também via pipeline. 
ANEXO 02 - COSO Internal Controls - Integrated Framework Principles - One Page

\section{COSO Internal Control Integrated Framework Principles}

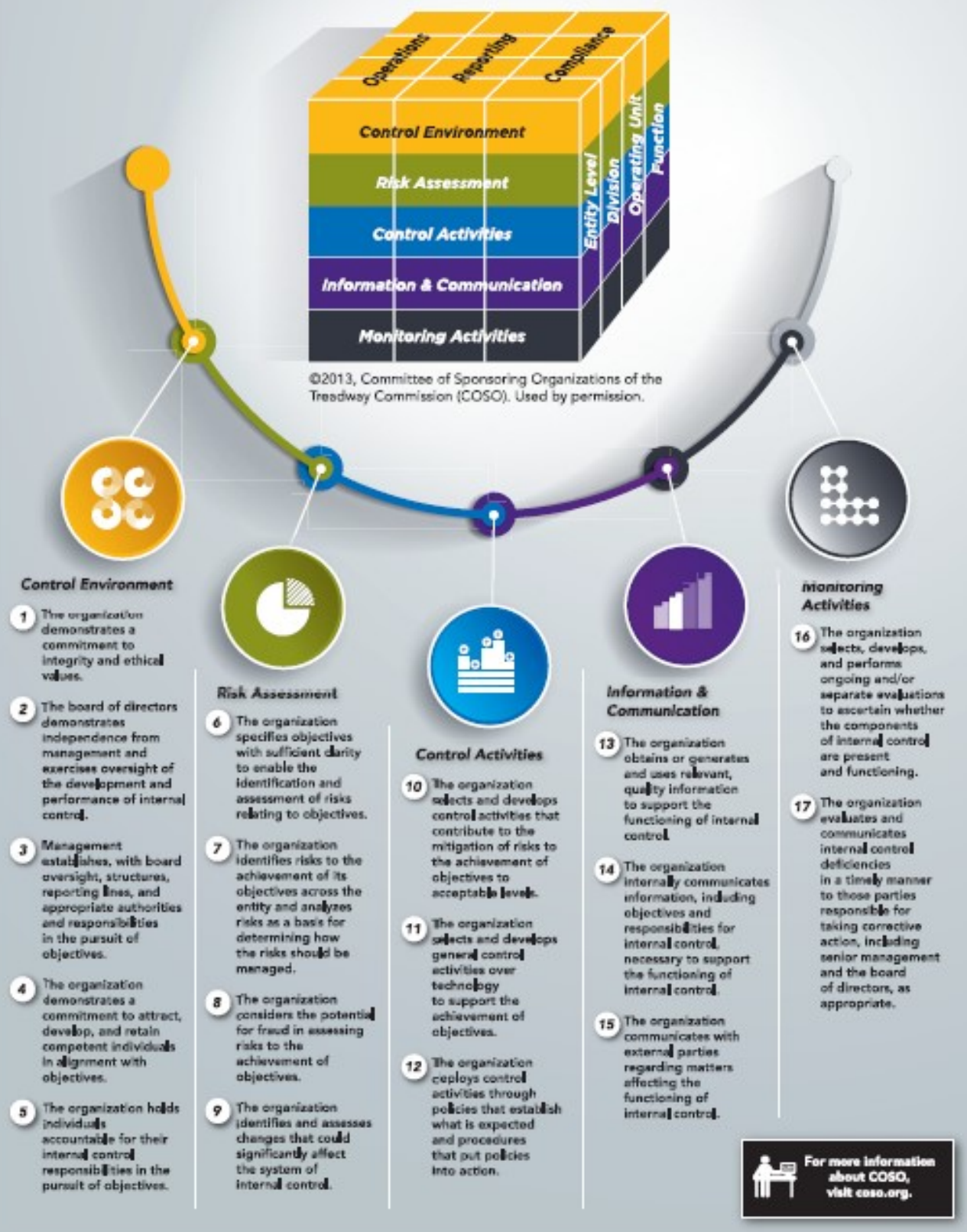




\section{ANEXO 03 - Modelo de Hillson (1997) - Atributos dos 4 Níveis de Maturidade de Risco \\ (Tradução livre do autor)}

\begin{tabular}{|c|c|c|c|}
\hline $\begin{array}{c}\text { NIVEL } 1 \\
\text { NAIVE ou INGENUO }\end{array}$ & $\begin{array}{c}\text { NIVEL } 2 \\
\text { NOVICE ou NOVATO }\end{array}$ & $\begin{array}{c}\text { NIVL } 3 \\
\text { NORMALISED ou } \\
\text { NORMATIZADO }\end{array}$ & $\begin{array}{l}\text { NIVELL } 4 \\
\text { NATURAL }\end{array}$ \\
\hline $\begin{array}{l}\text { Não está ciente da necessidade } \\
\text { de gerenciamento de risco. } \\
\text { Não possui estrutura para lidar } \\
\text { com incertezas. } \\
\text { Processo de gerenciamento } \\
\text { repetitivo e reativo. } \\
\text { Pouco ou nenhum aprendizado } \\
\text { como passado ou preparação } \\
\text { para o futuro. }\end{array}$ & $\begin{array}{l}\text { Tentativas em gerenciamento de } \\
\text { risco, através de um pequeno } \\
\text { número de colaboradores. } \\
\text { Não possui estrutura formal. } \\
\text { Ciente dos benefícios do } \\
\text { gerenciamento de risco, mas com } \\
\text { implementação ineficiente e com } \\
\text { ganhos parciais de beneficios. }\end{array}$ & $\begin{array}{l}\text { Gerenciamento de risco } \\
\text { construído sobre processos de } \\
\text { negócios de rotina. } \\
\text { Gerenciamento de risco } \\
\text { implementado nos principais ou } \\
\text { em todos os projetos. } \\
\text { Estrutura geral de gerenciamento } \\
\text { de riscos formalizada. } \\
\text { Beneficios conhecidos em todos } \\
\text { os níveis da organização, ainda } \\
\text { que não alcançados plenamente. }\end{array}$ & $\begin{array}{l}\text { Cultura de sensibilização a risco, } \\
\text { com gerenciamento de risco em } \\
\text { todos os processos de negócios. } \\
\text { Uso ativo de informações de risco } \\
\text { para incremento de processos de } \\
\text { negócios e ganho de vantagem } \\
\text { competitiva. } \\
\text { Enfase em gerenciamento de } \\
\text { oportunidade ("positive risk"). }\end{array}$ \\
\hline $\begin{array}{c}\text { Sem sensibilização para riscos. } \\
\text { Resistente/ relutante à mudança. } \\
\text { Tendência a continuar com os } \\
\text { processos existentes. }\end{array}$ & $\begin{array}{l}\text { Processos de risco são vistos } \\
\text { como custos adicionais com } \\
\text { benefícios variáveis. } \\
\text { Gerenciamento de risco apenas } \\
\text { para processos selecionados. }\end{array}$ & $\begin{array}{l}\text { Política de gerenciamento de } \\
\text { riscos aceita. } \\
\text { Beneficios reconhecidos e } \\
\text { esperados. } \\
\text { Preparada para comprometer } \\
\text { recursos para obter ganhos. }\end{array}$ & $\begin{array}{l}\text { Comprometimento com } \\
\text { gerenciamento de risco, tendo a } \\
\text { alta direção como exemplo. } \\
\text { Gerenciamento de risco pró-ativo, } \\
\text { encorajado e remunerado. }\end{array}$ \\
\hline Sem processos formais. & $\begin{array}{l}\text { Sem processos formais, embora } \\
\text { alguns métodos especificos } \\
\text { possam estar em uso. } \\
\text { Efetividade do processo depende } \\
\text { das habilidades do time interno e } \\
\text { de suporte externo. }\end{array}$ & $\begin{array}{c}\text { Processos genéricos aplicados a } \\
\text { todos os projetos. } \\
\text { Processos formais, incorporados } \\
\text { ao sistema de qualidade. } \\
\text { Orçamento para gerenciamento } \\
\text { de riscos alocado em todos os } \\
\text { níveis da organização. } \\
\text { Necessidade limitada de suporte } \\
\text { externo. }\end{array}$ & $\begin{array}{c}\text { Processos de negócios baseados } \\
\text { em risco. } \\
\text { Total Risk Management } \\
\text { permeando todo o negócio. } \\
\text { Revisão e atualização regular dos } \\
\text { processos. } \\
\text { Metricas de gerenciamento de } \\
\text { risco com constante feedback } \\
\text { para melhoria de performance. }\end{array}$ \\
\hline $\begin{array}{l}\text { Sem entendimento dos principios } \\
\text { ou linguagem de risco. }\end{array}$ & $\begin{array}{l}\text { Limitado a colaboradores com } \\
\text { pouco ou nenhum treinamento em } \\
\text { gerenciamento de risco. }\end{array}$ & $\begin{array}{l}\text { Time interno de experts, treinado } \\
\text { nas habilidades básicas. } \\
\text { Desenvolvimento de processose } \\
\text { ferramentas especificas. }\end{array}$ & $\begin{array}{c}\text { Toda a equipe com atitude de } \\
\text { sensibilização a riscose } \\
\text { conhecimento básico da } \\
\text { metodologia. } \\
\text { Aprendizado com a experiência } \\
\text { como parte do processo. } \\
\text { Treinamentos externos regulares } \\
\text { para aperfeiçoar habilidades. }\end{array}$ \\
\hline $\begin{array}{l}\text { Sem aplicação estruturada } \\
\text { Sem recursos dedicados } \\
\text { Sem ferramentas de } \\
\text { gerenciamento de risco }\end{array}$ & $\begin{array}{l}\text { Aplicação inconsistente. } \\
\text { Disponibilidade variável do time } \\
\text { interno. } \\
\text { Ferramentas e métodos } \\
\text { desenvolvidos internamento (ad } \\
\text { hoc). }\end{array}$ & $\begin{array}{c}\text { Aplicação consistente e rotineira a } \\
\text { todos os projetos. } \\
\text { Recursos alocados. } \\
\text { Conjunto integrado de } \\
\text { ferramentas e métodos. }\end{array}$ & $\begin{array}{l}\text { Gerenciamento de risco como } \\
\text { uma segunda natureza, aplicado a } \\
\text { todas as atividades. } \\
\text { Reportes e tomadas de decisão } \\
\text { baseadas em risco. } \\
\text { Ferramentas e métodos no estado } \\
\text { da arte. }\end{array}$ \\
\hline
\end{tabular}




\section{ANEXO 04 - Enterprise Risks In The Environment Of Value}

Oliva (2016) - Figura Original

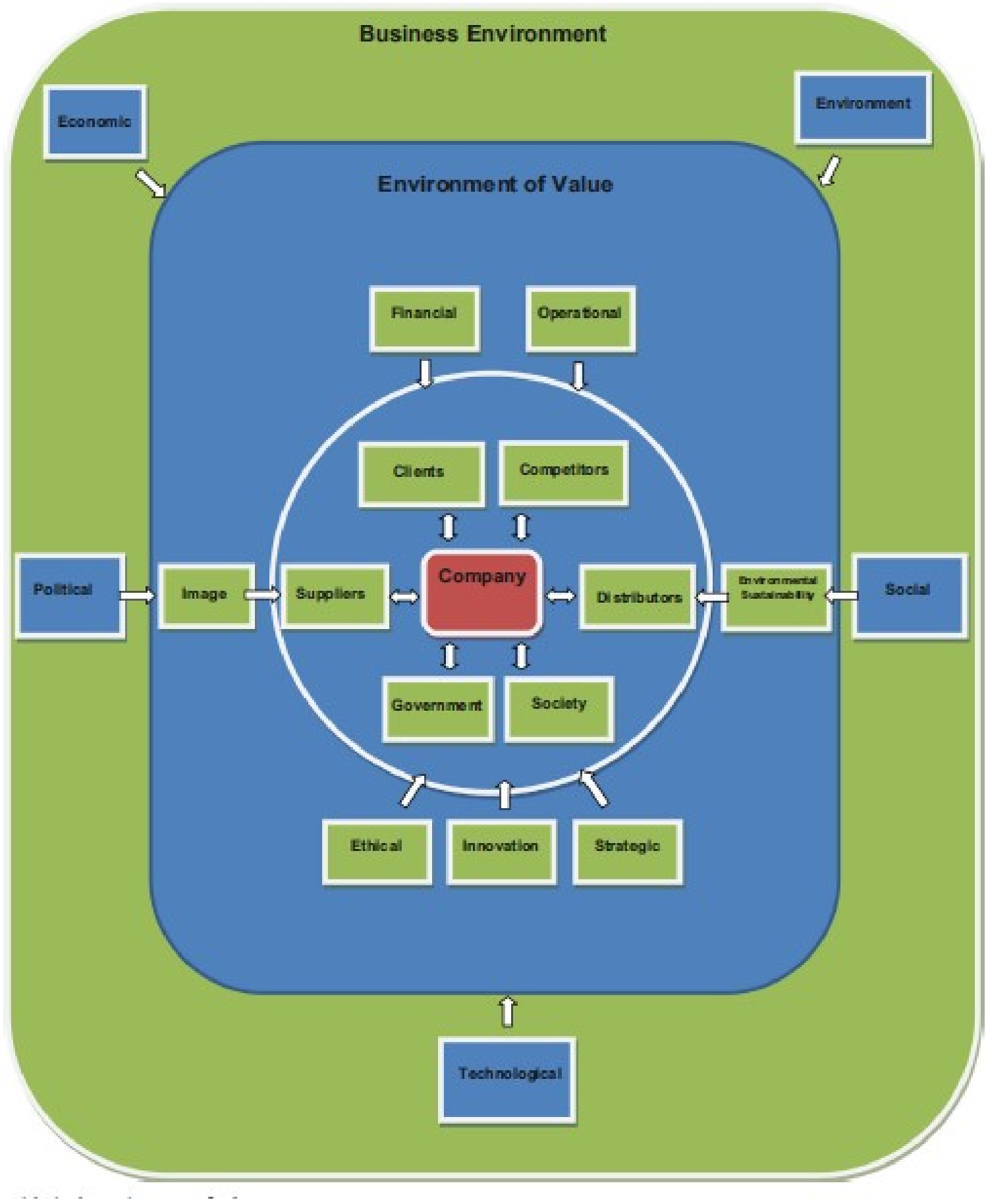




\section{APÊNDICE 01 - Questionário}

\section{INTRODUÇÃO}

Rogerio Meirelles é Gerente de Procurement South America para o negócio de PPC (Pulp \& Performance Chemicals) da AkzoNobel. Está cursando o Mestrado Profissional em Empreendedorismo na FEA - Faculdade de Economia e Administração da USP - Universidade de São Paulo. Sua dissertação para conclusão do Mestrado aborda o tema Gerenciamento de Riscos Corporativos e Avaliação de Maturidade Empresarial (no processo de Gerenciamento de Riscos Corporativos) na AkzoNobel, em seu negócio de PPC no Brasil. O Mestrando pede e agradece sua valiosíssima colaboração respondendo às perguntas abaixo, que irão ajudá-lo a desenhar a necessária avaliação, dentro das atividades declinadas, à conclusão de seu trabalho. A AkzoNobel concedeu a devida autorização para o trabalho, e nenhum dado confidencial será divulgado.

É importante que as perguntas sejam respondidas de modo a refletir a sua percepção a respeito do assunto, não havendo portanto respostas certas ou erradas. As respostas não precisam ser altamente elaboradas, mas o Mestrando solicita que se evitem simples "Sim" ou "Não", pois quer ter a oportunidade de conhecer a medida de sua percepcão.

Você pode optar por devolver o questionário em meio eletrônico ou impresso.

"A mente que se abre a uma nova idéia jamais voltará ao seu tamanho original"

Albert Einstein.

\section{IDENTIFICAÇÃO}

\begin{tabular}{|l|l|}
\hline NOME (opcional) & \\
\hline CARGO (opcional) & \\
\hline ÁREA DE ATUAÇÃO (necessário) & \\
\hline LOCAL DE TRABALHO (necessário) & \\
\hline
\end{tabular}


Por favor, considere em suas respostas o Ambiente de Valor e o Ambiente de Negócio onde a AkzoNobel PPC é a Organização:

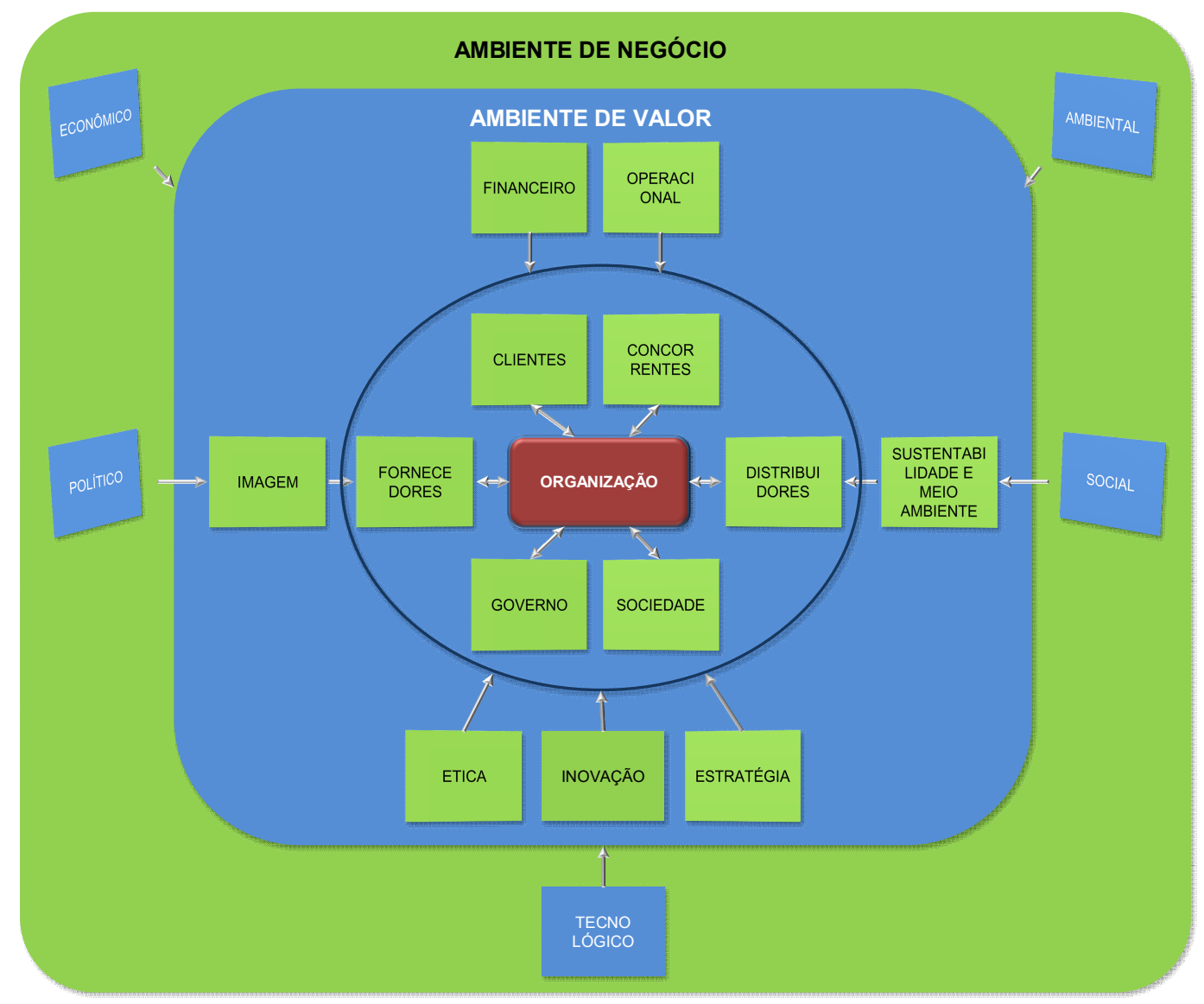

Riscos Empresariais no Ambiente de Valor Fonte: Oliva (2016), adaptado pelo autor (2017)

\section{PARTE 1 - QUESTÕES SOBRE GERENCIAMENTO DE RISCO CORPORATIVO}

1. A Alta Direção da AkzoNobel PPC está diretamente envolvida nas atividades de Gerenciamento de Risco ?

2. A AkzoNobel PPC mantém profissionais exclusivamente para gerenciar os controles internos da organização?

3. A AkzoNobel PPC especifica seus objetivos com clareza suficiente para possibilitar a identificação e avaliação dos riscos relacionados aos seus objetivos?

4. A AkzoNobel PPC considera fraudes em potencial quando avalia riscos relacionados aos atingimentos dos seus objetivos?

5. Os controles internos da AkzoNobel PPC são suportados por fontes de informação que possuam qualidade e confiança?

6. Como é a cultura de Gerenciamento de Riscos da AkzoNobel PPC ? 
7. A AkzoNobel PPC está preparada para gerenciar seus riscos internos ?

8. Considerando o modelo de negócios da AkzoNobel PPC, a que riscos você imagina que a empresa esteja exposta ? Por favor, cite-os ou exemplifique.

9. Que tipo de relação a AkzoNobel PPC possui com seus fornecedores ?

10. Existem outros agentes que não foram relacionados no modelo de Riscos Empresariais no Ambiente de Valor? Por favor, cite-os ou exemplifique.

11. A AkzoNobel PPC está preparada para gerenciar seus riscos externos ?

12. A AkzoNobel PPC audita constantemente seus controles internos para verificar sua efetividade ?

13. A AkzoNobel PPC comunica adequadamente à organização qual é o seu plano de Gerenciamento de Riscos?

\section{PARTE 2 - QUESTÕES SOBRE AVALIAÇÃO DE MATURIDADE EMPRESARIAL}

1. A AkzoNobel PPC é ciente da necessidade de possuir uma atividade estruturada de Gerenciamento de Risco?

2. A AkzoNobel PPC é ciente dos ganhos advindos de possuir uma estrutura eficaz de Gerenciamento de Risco?

3. A AkzoNobel PPC enxerga o Gerenciamento de Risco como custo ou benefício ?

4. A AkzoNobel PPC demonstra a intenção de investir em melhorias de suas atividades de gerenciamento de risco?

5. A AkzoNobel PPC possui uma estrutura centralizada de Gerenciamento de Riscos Corporativos ?

6. Existe um orçamento específico para atividades de Gerenciamento de Risco ?

7. Os colaboradores envolvidos no processo de gerenciamento de risco da AkzoNobel PPC possuem treinamento específico para isso?

8. A AkzoNobel PPC possui ferramenta de Gerenciamento de Riscos ?

9. O processo de Gerenciamento de Risco da AkzoNobel PPC depende de pessoas ou possui um método de suporte que o sustente?

10. A AkzoNobel PPC estabelece Gerenciamento de Risco para todas as suas atividades e processos ?

11. A AkzoNobel PPC enfrenta resistência dos funcionários para realizar atividades de Gerenciamento de Risco?

12. Você conhece a forma como a AkzoNobel PPC toma decisões sobre Gerenciamento de Riscos ?

13. A AkzoNobel PPC comunica adequadamente à organização qual é o seu plano de Gerenciamento de Risco? 
14. A AkzoNobel PPC contrata expertises externas (consultores e parceiros) para fortalecer seu processo de Gerenciamento de Risco ?

15. A AkzoNobel PPC avalia seus riscos considerando também o ambiente externo à organização (ver figura Riscos Empresariais no Ambiente de Valor)?

\section{ESPAÇO LIVRE PARA QUALQUER COMENTÁRIO SOBRE O TEMA:}

Muito obrigado pela sua gentileza em me atender e pela sua colaboração com meu aprendizado. Meirelles.

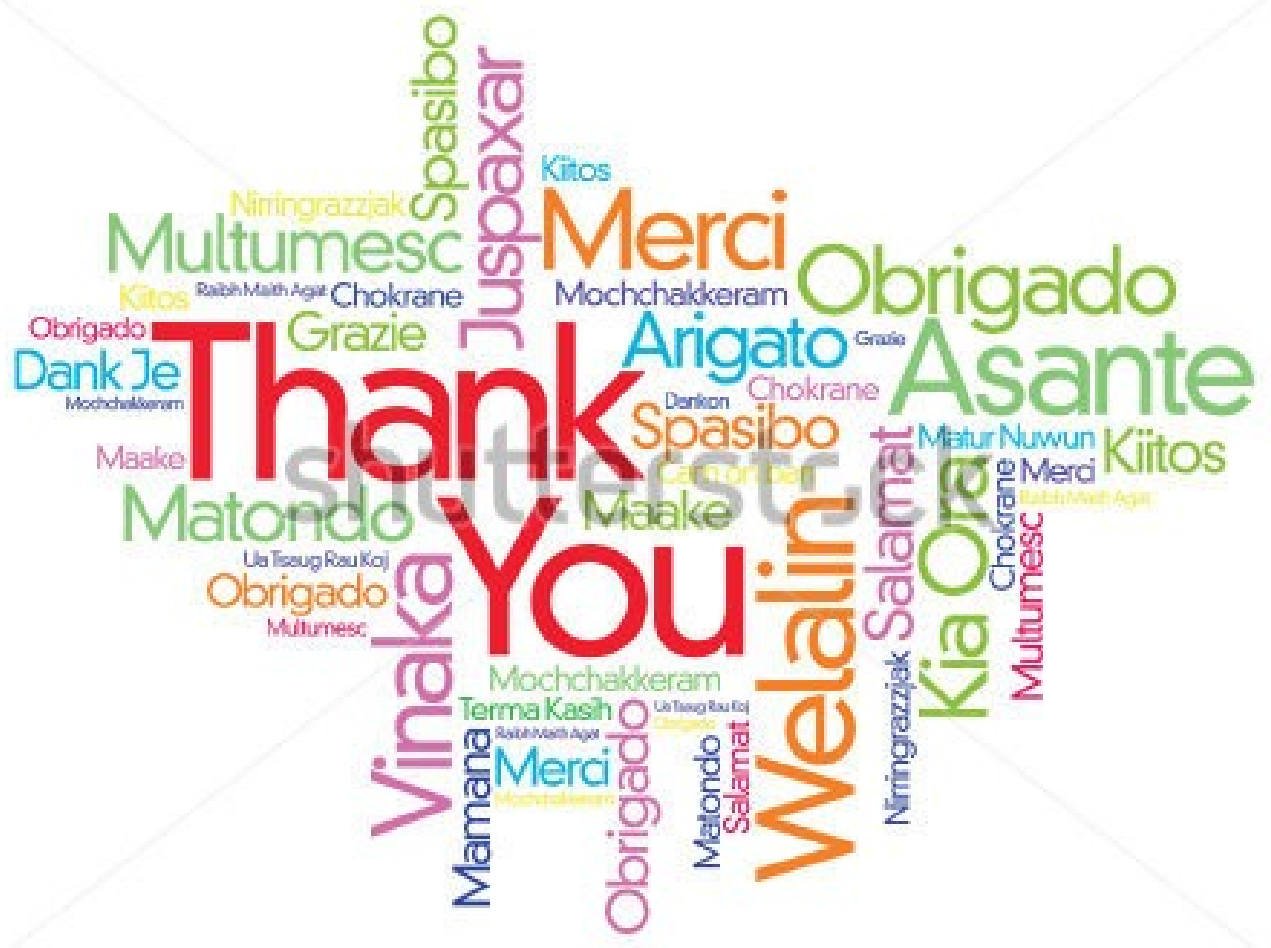


APÊNDICE 02 - Respostas Agrupadas - Parte 1 - Gerenciamento de Risco Corporativo

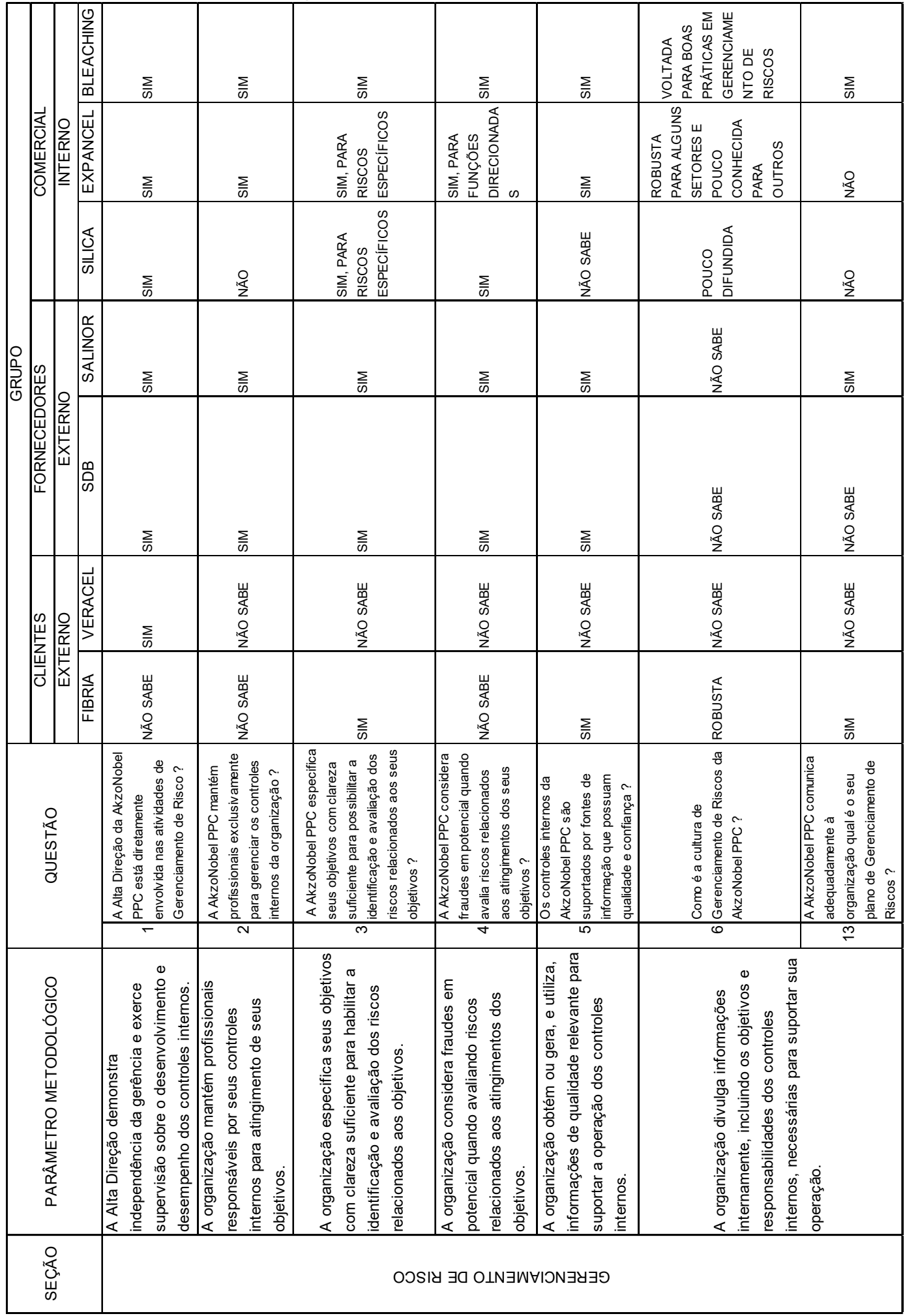




\begin{tabular}{|c|c|c|c|c|c|c|c|c|c|}
\hline 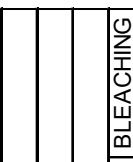 & 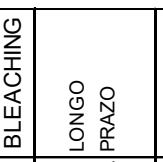 & $\frac{\pi}{z}$ & 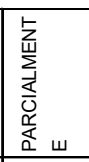 & $\frac{\sum}{\omega}$ & $\frac{\Sigma}{\infty}$ & 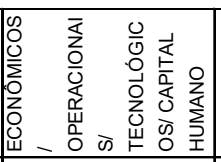 & $\frac{\pi}{z}$ & 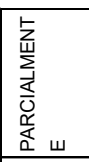 & $\frac{\sum}{\omega}$ \\
\hline 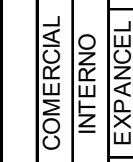 & 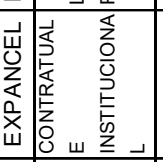 & $\frac{T}{\alpha}$ & 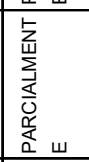 & $\frac{\sum}{\omega}$ & $\frac{\sum}{\infty}$ & 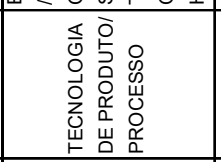 & $\frac{T}{\underline{N}}$ & 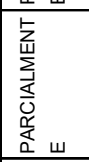 & $\frac{\frac{5}{\omega}}{\omega}$ \\
\hline & 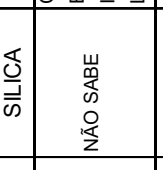 & 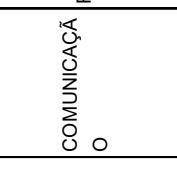 & 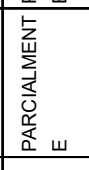 & 迹 & 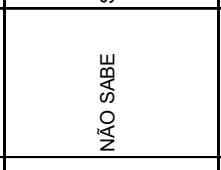 & 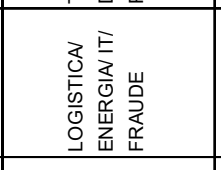 & 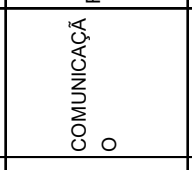 & 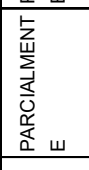 & 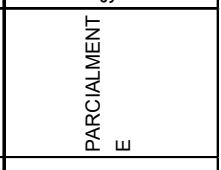 \\
\hline 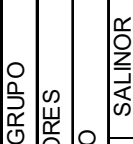 & 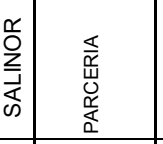 & 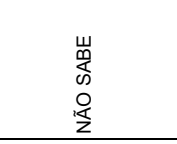 & $\frac{\Sigma}{\omega}$ & $\frac{\sum}{n}$ & $\frac{\Sigma}{\omega}$ & 过 & 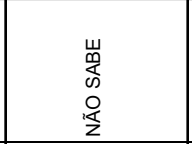 & $\frac{\sum}{\omega}$ & $\frac{\Sigma}{\omega}$ \\
\hline 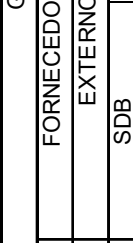 & 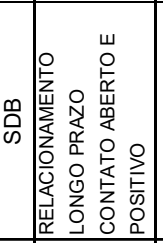 & 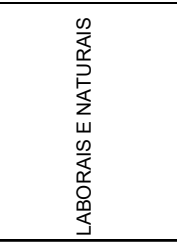 & 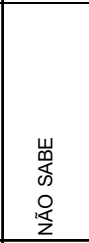 & 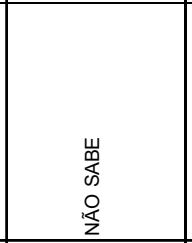 & $\frac{\sum}{\infty}$ & 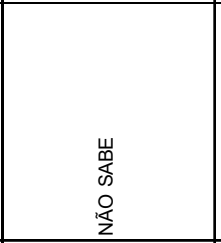 & 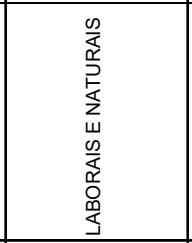 & 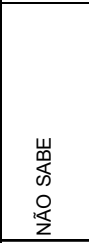 & $\frac{\sum}{\omega}$ \\
\hline 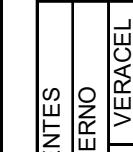 & 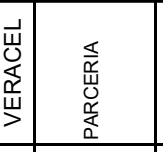 & $\frac{8}{2}$ & 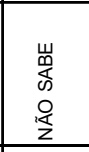 & 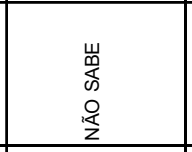 & 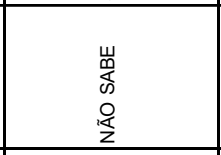 & 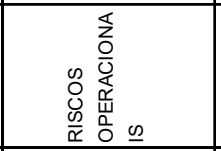 & 迹 & 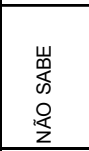 & $\frac{\sum}{\omega}$ \\
\hline 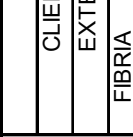 & 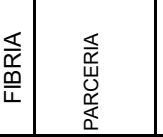 & is & 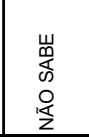 & $\sum$ & $\sum$ & 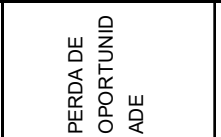 & is & 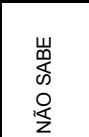 & $\frac{\pi}{z}$ \\
\hline 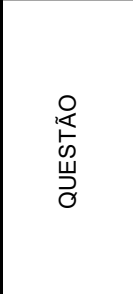 & 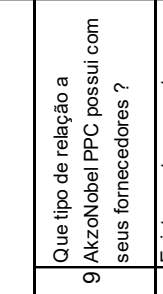 & 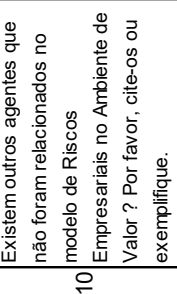 & 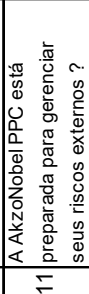 & 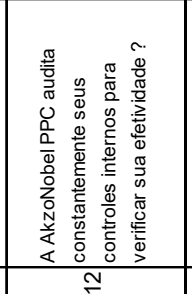 & 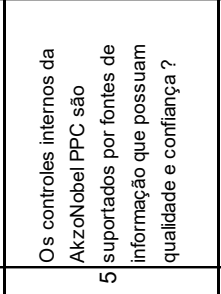 & 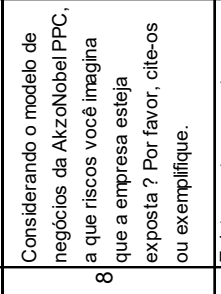 & 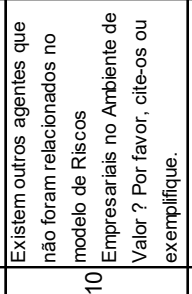 & 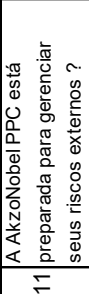 & 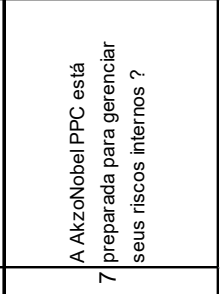 \\
\hline 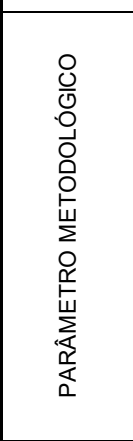 & & 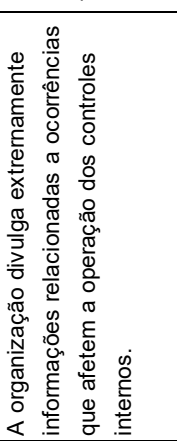 & & 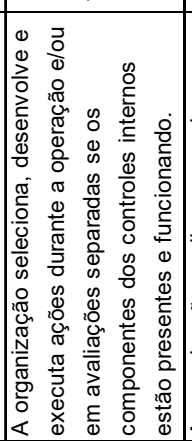 & 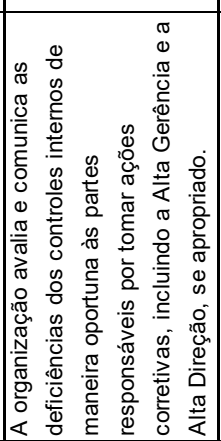 & 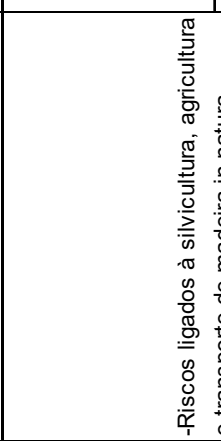 & 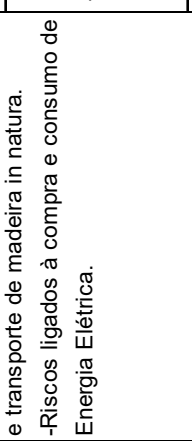 & & 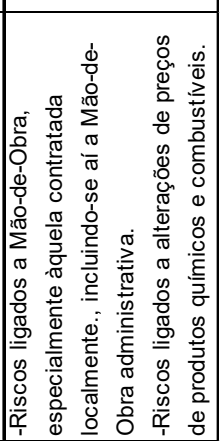 \\
\hline 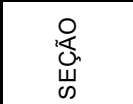 & \multicolumn{9}{|c|}{ 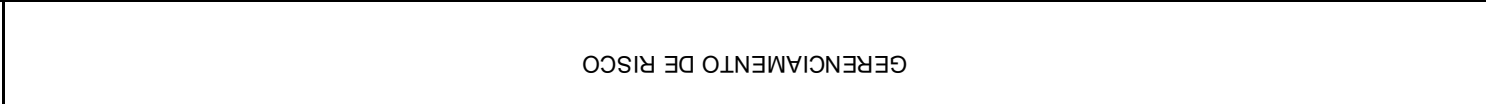 } \\
\hline
\end{tabular}




\begin{tabular}{|c|c|c|c|c|c|c|c|}
\hline 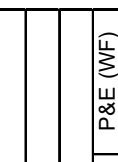 & $\frac{\sum}{\omega}$ & $\frac{\sum}{\omega}$ & $\frac{\Sigma}{\omega}$ & $\frac{\sum}{\omega}$ & 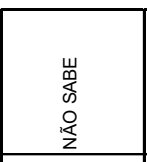 & 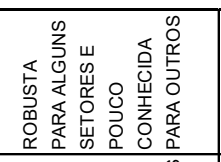 & $\frac{8}{2}$ \\
\hline 党 & $\frac{\sum}{w}$ & $\frac{\sum}{\infty}$ & $\frac{\sum}{\omega}$ & 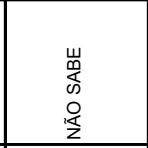 & 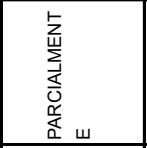 & 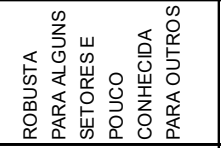 & 是 \\
\hline 竧岕 & $\frac{\Sigma}{\omega}$ & $\frac{\sum}{\infty}$ & $\frac{\Sigma}{\omega}$ & $\frac{\Sigma}{\infty}$ & $\frac{\Sigma}{\infty}$ & 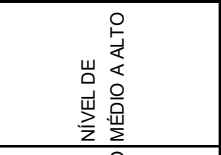 & $\frac{8}{2}$ \\
\hline & $\frac{\sum}{\infty}$ & 迹 & 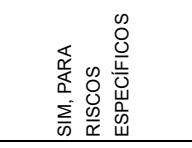 & 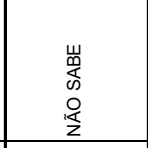 & $\frac{\Sigma}{\omega}$ & 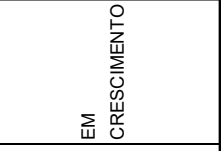 & 是 \\
\hline & $\frac{\Sigma}{\omega}$ & $\frac{\Sigma}{\omega}$ & $\frac{8}{2}$ & $\frac{\Sigma}{\omega}$ & $\frac{5}{\omega}$ & $\begin{array}{l}\frac{5}{3} \\
\frac{1}{2} \\
\frac{1}{2} \\
\end{array}$ & 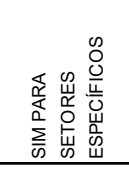 \\
\hline 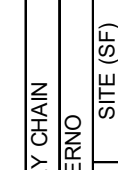 & 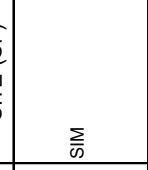 & 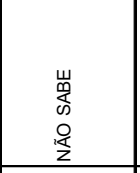 & 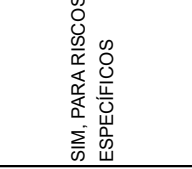 & 过 & $\frac{\Sigma}{\sigma}$ & 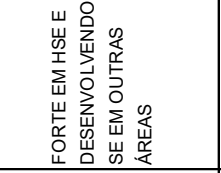 & $\frac{8}{2}$ \\
\hline 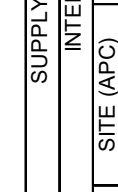 & 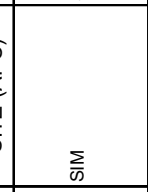 & $\frac{\Sigma}{\omega}$ & 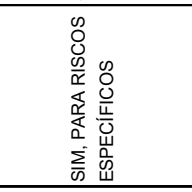 & 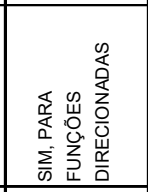 & $\frac{\sum}{\omega}$ & 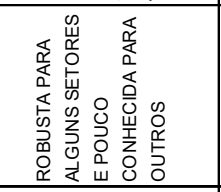 & 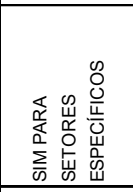 \\
\hline 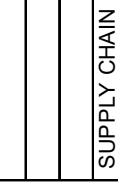 & $\frac{\Sigma}{\sigma}$ & 造 & $\frac{8}{2}$ & $\frac{\Sigma}{0}$ & 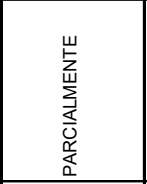 & 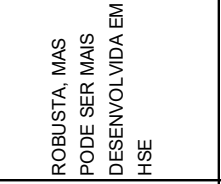 & $\frac{9}{2}$ \\
\hline 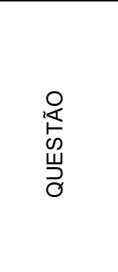 & 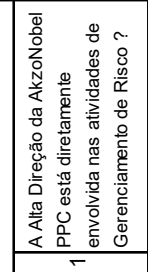 & 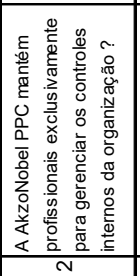 & 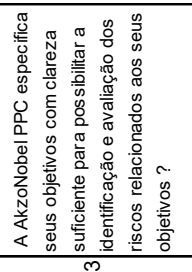 & 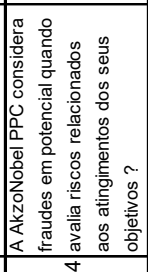 & 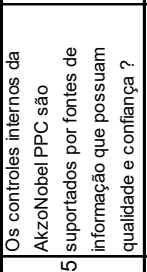 & 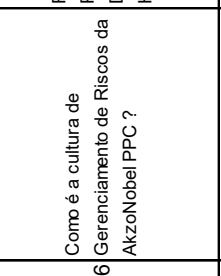 & 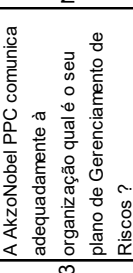 \\
\hline 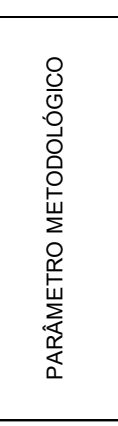 & 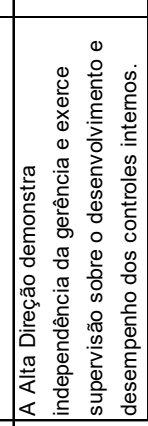 & 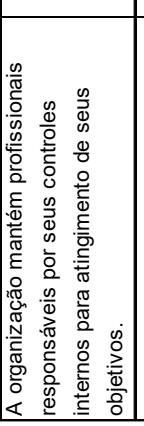 & 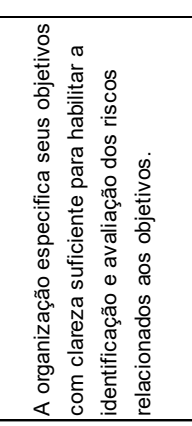 & 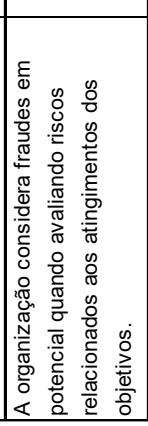 & 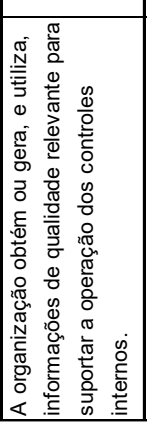 & 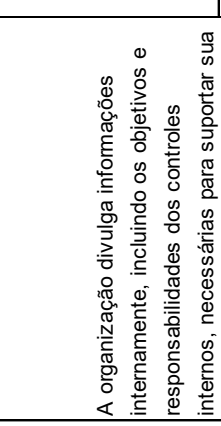 & 0 \\
\hline 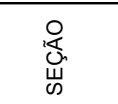 & \multicolumn{7}{|c|}{ 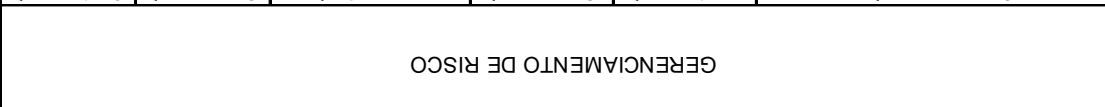 } \\
\hline
\end{tabular}




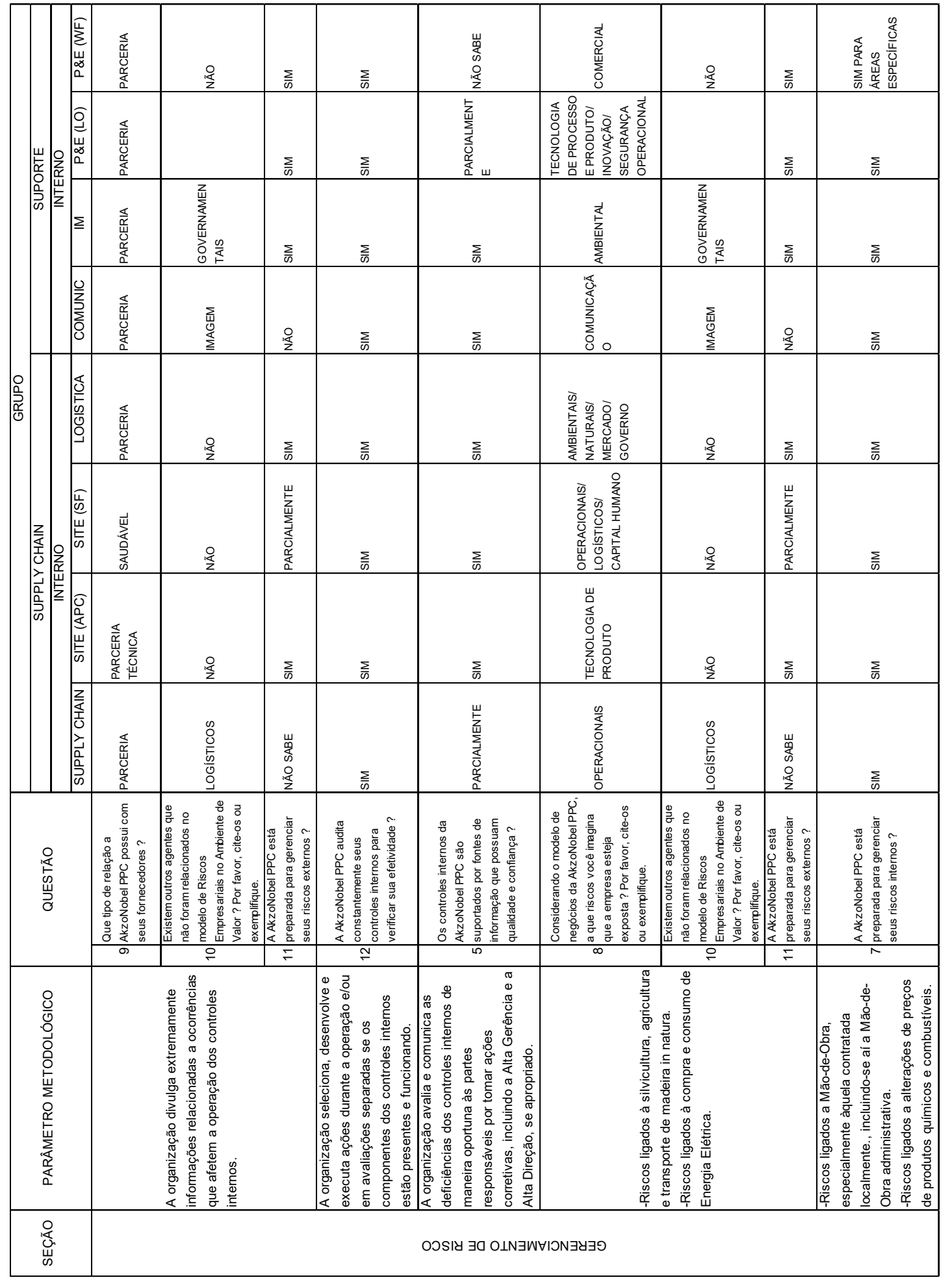




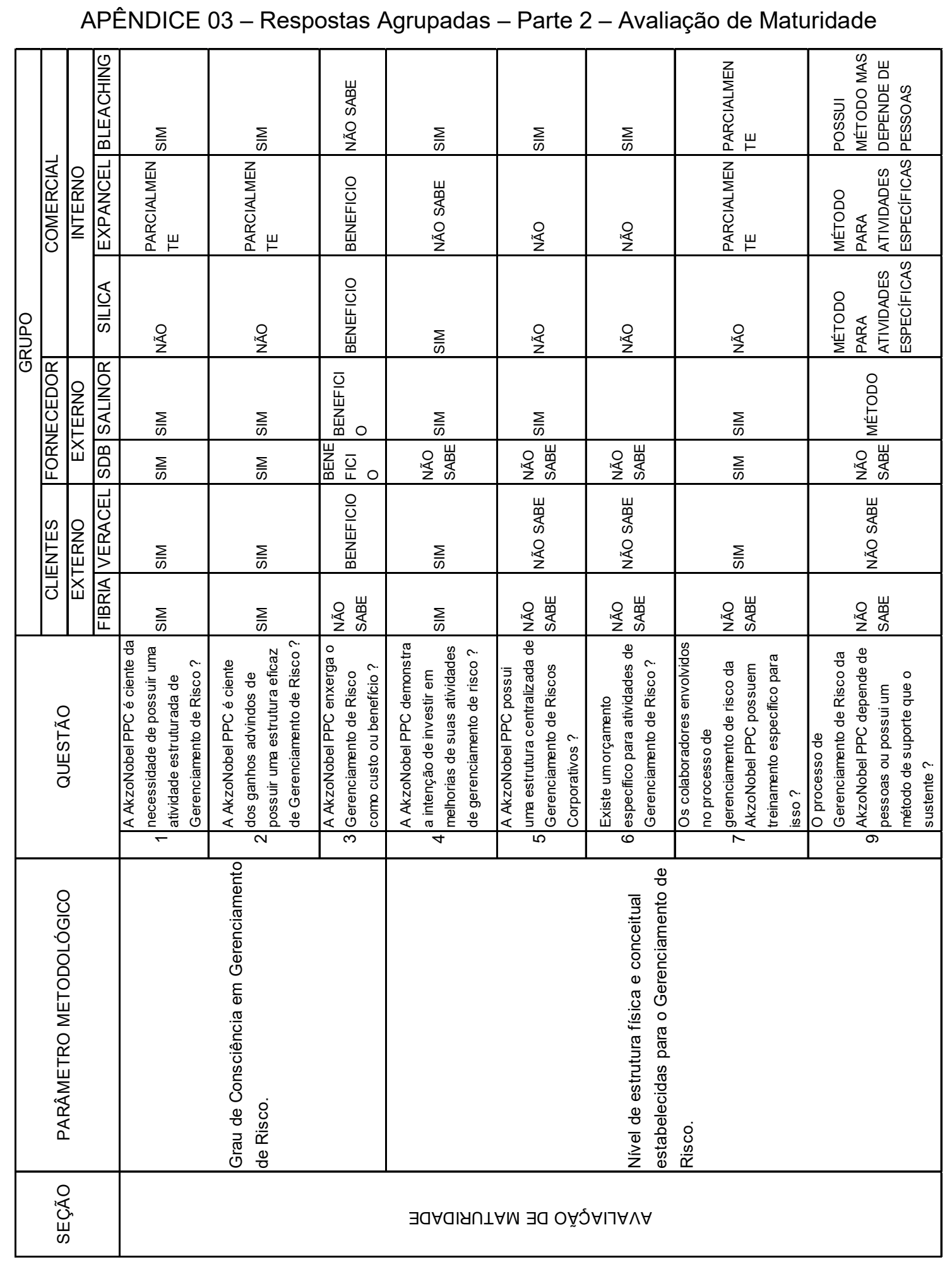




\begin{tabular}{|c|c|c|c|c|c|c|c|c|c|c|}
\hline \multirow{4}{*}{ SEÇÃO } & \multirow{4}{*}{ PERGUNTA } & \multirow{4}{*}{\multicolumn{2}{|c|}{ QUESTÃO }} & \multicolumn{7}{|c|}{ GRUPO } \\
\hline & & & & \multirow{2}{*}{\multicolumn{2}{|c|}{$\begin{array}{r}\text { CLIENTES } \\
\text { EXTERNO }\end{array}$}} & \multirow{2}{*}{\multicolumn{2}{|c|}{\begin{tabular}{|c|} 
FORNECEDOR \\
EXTERNO
\end{tabular}}} & \multicolumn{3}{|c|}{ COMERCIAL } \\
\hline & & & & & & & & & INTERNO & \\
\hline & & & & $\overline{\text { FIBRIA }}$ & VERACEL & SDB & SALINOR & SILICA & EXPANCEL & BLEACHING \\
\hline \multirow{12}{*}{ 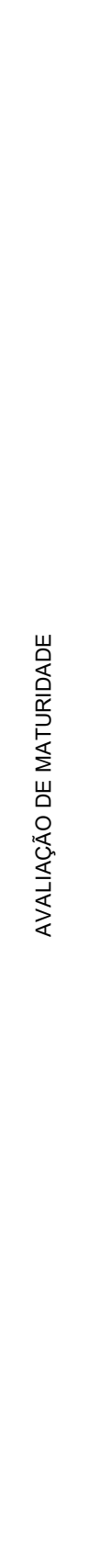 } & \multirow{2}{*}{$\begin{array}{l}\text { Nível de utilização de técnicas, } \\
\text { ferramentas e métodos de } \\
\text { Gerenciamento de Risco. }\end{array}$} & 8 & $\begin{array}{l}\text { A AkzoNobel PPC possui } \\
\text { ferramenta de Gerenciamento } \\
\text { de Riscos? }\end{array}$ & $\begin{array}{l}\text { NÃO } \\
\text { SABE }\end{array}$ & NÃO SABE & SIM & SIM & NÃO & $\begin{array}{l}\text { PARCIALMEN } \\
\text { TE }\end{array}$ & SIM \\
\hline & & 10 & $\begin{array}{l}\text { A AkzoNobel PPC estabelece } \\
\text { Gerenciamento de Risco para } \\
\text { todas as suas atividades e } \\
\text { processos? }\end{array}$ & $\begin{array}{l}\text { PARCIA } \\
\text { LMENT } \\
\text { E }\end{array}$ & NÃO SABE & $\begin{array}{l}N A ̃ O \\
\text { SABE }\end{array}$ & SIM & $\begin{array}{l}\text { PARCIALMEN } \\
\text { TE }\end{array}$ & NÃO & $\begin{array}{l}\text { PARCIALMEN } \\
\text { TE }\end{array}$ \\
\hline & $\begin{array}{l}\text { Grau de envolvimento dos } \\
\text { colaboradores em geral nas atividades } \\
\text { de Gerenciamento de Risco. }\end{array}$ & 11 & $\begin{array}{l}\text { A AkzoNobel PPC enfrenta } \\
\text { resistência dos funcionários } \\
\text { para realizar atividades de } \\
\text { Gerenciamento de Risco? }\end{array}$ & SIM & NÃO SABE & $\begin{array}{l}N A ̃ O \\
\text { SABE }\end{array} \mid$ & NÃO & NÃO SABE & NÃO & NÃO \\
\hline & \multirow{4}{*}{$\begin{array}{l}\text { Grau de organização dos processos } \\
\text { relacionados a Gerenciamento de Risco. }\end{array}$} & 2 & $\begin{array}{l}\text { A AkzoNobel PPC é ciente } \\
\text { dos ganhos advindos de } \\
\text { possuir uma estrutura eficaz } \\
\text { de Gerenciamento de Risco? }\end{array}$ & SIM & SIM & SIM & SIM & NÃO & $\begin{array}{l}\text { PARCIALMEN } \\
\text { TE }\end{array}$ & SIM \\
\hline & & 6 & $\begin{array}{l}\text { Existe um orçamento } \\
\text { especifico para atividades de } \\
\text { Gerenciamento de Risco? }\end{array}$ & $\begin{array}{l}\text { NÃO } \\
\text { SABE }\end{array}$ & NÃO SABE & $\begin{array}{l}\text { NÃO } \\
\text { SABE }\end{array}$ & 0 & NÃO & NÃO & SIM \\
\hline & & & $\begin{array}{l}\text { Os colaboradores envolvidos } \\
\text { no processo de } \\
\text { gerenciamento de risco da } \\
\text { AkzoNobel PPC possuem } \\
\text { treinamento especifico para } \\
\text { isso? }\end{array}$ & SÃO & SIM & SIM & SIM & NÃO & $\begin{array}{l}\text { PARCIALMEN } \\
\text { TE }\end{array}$ & $\begin{array}{l}\text { PARCIALMEN } \\
\text { TE }\end{array}$ \\
\hline & & 9 & $\begin{array}{l}\text { O processo de } \\
\text { Gerenciamento de Risco da } \\
\text { AkzoNobel PPC depende de } \\
\text { pessoas ou possui um } \\
\text { método de suporte que o } \\
\text { sustente? }\end{array}$ & $\begin{array}{l}\text { NÃO } \\
\text { SABE }\end{array}$ & NÃO SABE & $\begin{array}{l}\text { NÃO } \\
\text { SABE }\end{array}$ & MÉTODO & $\begin{array}{l}\text { MÉTODO } \\
\text { PARA } \\
\text { ATIVIDADES } \\
\text { ESPECÍFICAS }\end{array}$ & \begin{tabular}{|l|} 
MÉTODO \\
PARA \\
ATIVIDADES \\
ESPECÍFICAS
\end{tabular} & $\begin{array}{l}\text { POSSUI } \\
\text { MÉTODO MAS } \\
\text { DEPENDE DE } \\
\text { PESSOAS }\end{array}$ \\
\hline & $\begin{array}{l}\text { Grau de centralização das atividades de } \\
\text { Gerenciamento de Risco. }\end{array}$ & 5 & $\begin{array}{l}\text { A AkzoNobel PPC possui } \\
\text { uma estrutura centralizada de } \\
\text { Gerenciamento de Riscos } \\
\text { Corporativos? }\end{array}$ & SAB̃ & NÃO SABE & $\begin{array}{l}\text { NÂO } \\
\text { SABE }\end{array} \mid$ & SIM & NÃO & NÃO & SIM \\
\hline & \multirow{2}{*}{$\begin{array}{l}\text { Importância da Comunicação interna e } \\
\text { externa nos processos de } \\
\text { Gerenciamento de Risco. }\end{array}$} & 12 & $\begin{array}{l}\text { Você conhece a forma como } \\
\text { a AkzoNobel PPC toma } \\
\text { decisões sobre } \\
\text { Gerenciamento de Riscos? }\end{array}$ & $\begin{array}{l}\text { PARCIA } \\
\text { LMENT } \\
\text { E }\end{array}$ & NÃO & NÃO & & NÃO & $\begin{array}{l}\text { PARCIALMEN } \\
\text { TE }\end{array}$ & SIM \\
\hline & & 13 & $\begin{array}{l}\text { A AkzoNobel PPC comunica } \\
\text { adequadamente à } \\
\text { organização qual é o seu } \\
\text { plano de Gerenciamento de } \\
\text { Risco? }\end{array}$ & NÃO & NÃO & $\begin{array}{l}\text { NÃO } \\
\text { SABE }\end{array} \mid$ & SIM & NÃO & NÃO & $\begin{array}{l}\text { PARCIALMEN } \\
\text { TE }\end{array}$ \\
\hline & $\begin{array}{l}\text { Utilização de expertise externa } \\
\text { (consultorias e parceiros) em seu } \\
\text { processo de Gerenciamento de Risco. }\end{array}$ & 14 & $\begin{array}{l}\text { A AkzoNobel PPC contrata } \\
\text { expertises externas } \\
\text { (consultores e parceiros) } \\
\text { para fortalecer seu processo } \\
\text { de Gerenciamento de Risco? }\end{array}$ & $\begin{array}{l}\text { NÃO } \\
\text { SABE }\end{array}$ & NÃO SABE & $\begin{array}{l}\text { NÃO } \\
\text { SABE }\end{array}$ & & NÃO SABE & SIM & SIM \\
\hline & $\begin{array}{l}\text { Avaliação de risco transcendente ao } \\
\text { ambiente de valor da companhia } \\
\text { (interno), inlcuindo o ambiente de } \\
\text { negócio (externo). }\end{array}$ & 15 & $\begin{array}{l}\text { A AkzoNobel PPC avalia } \\
\text { seus riscos considerando } \\
\text { também o ambiente externo à } \\
\text { organização (ver figura } \\
\text { Riscos Empresariais no } \\
\text { Ambiente de Valor)? }\end{array}$ & $\begin{array}{l}\text { NÃO } \\
\text { SABE }\end{array}$ & SIM & SIM & SIM & NÃO SABE & NÃO & SIM \\
\hline
\end{tabular}




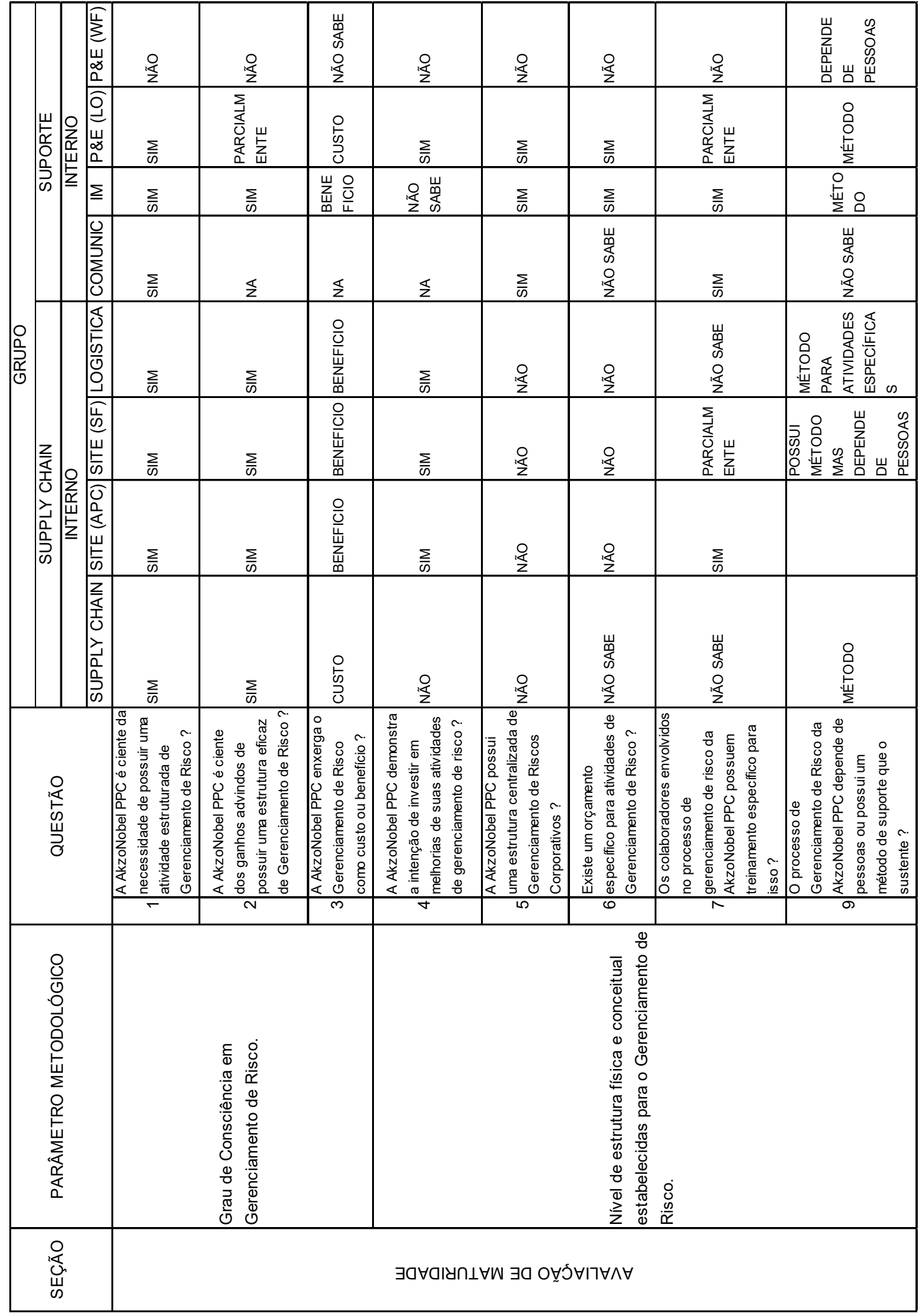




\begin{tabular}{|c|c|c|c|c|c|c|c|c|c|c|c|}
\hline \multirow{4}{*}{ SEÇÃO } & \multirow{4}{*}{ PERGUNTA } & \multirow{4}{*}{\multicolumn{2}{|c|}{ QUESTÃO }} & \multicolumn{8}{|c|}{ GRUPO } \\
\hline & & & & \multirow{2}{*}{\multicolumn{4}{|c|}{$\begin{array}{c}\text { SUPPLY CHAIN } \\
\text { INTERNO }\end{array}$}} & \multicolumn{4}{|c|}{ SUPORTE } \\
\hline & & & & & & & & & & TERNO & \\
\hline & & & & SUPPLY CHAIN & SITE (APC) & SITE (SF) & LOGISTICA & COMUNIC & IM & P\&E (LO) & P\&E (WF) \\
\hline \multirow{12}{*}{ 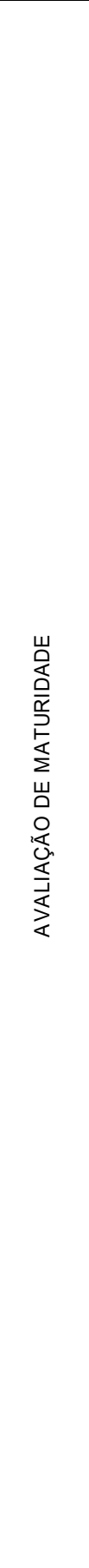 } & \multirow{2}{*}{$\begin{array}{l}\text { Nível de utilização de técnicas, } \\
\text { ferramentas e métodos de } \\
\text { Gerenciamento de Risco. }\end{array}$} & 8 & $\begin{array}{l}\text { A AkzoNobel PPC possui } \\
\text { ferramenta de Gerenciamento } \\
\text { de Riscos? }\end{array}$ & SIM & $\left|\begin{array}{l}\text { PARCIALMEN } \\
\text { TE }\end{array}\right|$ & $\begin{array}{l}\text { PARCIALM } \\
\text { ENTE }\end{array}$ & SIM & SIM & SIM & SIM & $\begin{array}{l}\text { PARCIALM } \\
\text { ENTE }\end{array}$ \\
\hline & & 10 & \begin{tabular}{|l|} 
A AkzoNobel PPC estabelece \\
Gerenciamento de Risco \\
para todas as suas \\
atividades e processos?
\end{tabular} & PARCIALMENTE & $\mid \begin{array}{l}\text { PARCIALMEN } \\
\text { TE }\end{array}$ & $\begin{array}{l}\text { PARCIALM } \\
\text { ENTE }\end{array}$ & SIM & NÃO & $\begin{array}{l}\text { PARCI } \\
\text { ALME } \\
\text { NTE }\end{array}$ & $\begin{array}{l}\text { PARCIALM } \\
\text { ENTE }\end{array}$ & NÃO \\
\hline & $\begin{array}{l}\text { Grau de envolvimento dos } \\
\text { colaboradores em geral nas atividades } \\
\text { de Gerenciamento de Risco. }\end{array}$ & 11 & $\begin{array}{l}\text { A AkzoNobel PPC enfrenta } \\
\text { resistência dos funcionários } \\
\text { para realizar atividades de } \\
\text { Gerenciamento de Risco? }\end{array}$ & NÃO & NÃO & $\begin{array}{l}\text { PARCIALM } \\
\text { ENTE }\end{array}$ & NÃO & SIM & $\begin{array}{l}\text { NÃO } \\
\text { SABE }\end{array}$ & SIM & NÃO \\
\hline & \multirow{4}{*}{$\begin{array}{l}\text { Grau de organização dos processos } \\
\text { relacionados a Gerenciamento de } \\
\text { Risco. }\end{array}$} & 2 & \begin{tabular}{|l} 
A AkzoNobel PPC é ciente \\
dos ganhos advindos de \\
possuir uma estrutura eficaz \\
de Gerenciamento de Risco?
\end{tabular} & SIM & SIM & SIM & SIM & NA & SIM & \begin{tabular}{|l|} 
PARCIALM \\
ENTE
\end{tabular} & NÃO \\
\hline & & 6 & $\begin{array}{l}\text { Existe um orçamento } \\
\text { especifico para atividades de } \\
\text { Gerenciamento de Risco? }\end{array}$ & NÃO SABE & NÃO & NÃO & NÃO & NÃO SABE & SIM & SIM & NÃO \\
\hline & & 7 & $\begin{array}{l}\text { Os colaboradores envolvidos } \\
\text { no processo de } \\
\text { gerenciamento de risco da } \\
\text { AkzoNobel PPC possuem } \\
\text { treinamento especifico para } \\
\text { isso? }\end{array}$ & NÃO SABE & SIM & $\begin{array}{l}\text { PARCIALM } \\
\text { ENTE }\end{array}$ & NÃO SABE & SIM & SIM & \begin{tabular}{|l|} 
PARCIALM \\
ENTE
\end{tabular} & NÃO \\
\hline & & 9 & \begin{tabular}{|l|} 
O processo de \\
Gerenciamento de Risco da \\
AkzoNobel PPC depende de \\
pessoas ou possui um \\
método de suporte que o \\
sustente?
\end{tabular} & MÉTODO & 0 & $\begin{array}{l}\text { POSSUI } \\
\text { MÉTODO } \\
\text { MAS } \\
\text { DEPENDE } \\
\text { DE } \\
\text { PESSOAS }\end{array}$ & $\begin{array}{l}\text { MÉTODO } \\
\text { PARA } \\
\text { ATIVIDADES } \\
\text { ESPECIFICA } \\
\text { S }\end{array}$ & NÃO SABE & $\begin{array}{l}\text { MÉTO } \\
\text { DO }\end{array}$ & MÉTODO & $\begin{array}{l}\text { DEPENDE } \\
\text { DE } \\
\text { PESSOAS }\end{array}$ \\
\hline & $\begin{array}{l}\text { Grau de centralização das atividades de } \\
\text { Gerenciamento de Risco. }\end{array}$ & 5 & \begin{tabular}{|l|} 
A AkzoNobel PPC possui \\
uma estrutura centralizada de \\
Gerenciamento de Riscos \\
Corporativos?
\end{tabular} & NÃO & NÃO & NÃO & NÃO & SIM & SIM & SIM & NÃO \\
\hline & \multirow{2}{*}{$\begin{array}{l}\text { Importância da Comunicação interna e } \\
\text { externa nos processos de } \\
\text { Gerenciamento de Risco. }\end{array}$} & 12 & $\begin{array}{l}\text { Você conhece a forma como } \\
\text { a AkzoNobel PPC toma } \\
\text { decisões sobre } \\
\text { Gerenciamento de Riscos? }\end{array}$ & NÃO SABE & & SIM & NÃO & NÃO & $\begin{array}{l}\text { PARCI } \\
\text { ALME } \\
\text { NTE }\end{array}$ & \begin{tabular}{|l} 
PARCIALM \\
ENTE
\end{tabular} & NÃO \\
\hline & & 13 & \begin{tabular}{|l|} 
A AkzoNobel PPC comunica \\
adequadamente à \\
organização qual é o seu \\
plano de Gerenciamento de \\
Risco?
\end{tabular} & NÃO & \begin{tabular}{|l} 
PARCIALMEN \\
TE
\end{tabular} & $\begin{array}{l}\text { PARCIALM } \\
\text { ENTE }\end{array}$ & SIM & NÃO & NÃO & NÃO & NÃO \\
\hline & $\begin{array}{l}\text { Utilização de expertise externa } \\
\text { (consultorias e parceiros) em seu } \\
\text { processo de Gerenciamento de Risco. }\end{array}$ & 14 & \begin{tabular}{|l} 
A AkzoNobel PPC contrata \\
expertises externas \\
(consultores e parceiros) \\
para fortalecer seu processo \\
de Gerenciamento de Risco?
\end{tabular} & NÃO SABE & SIM & SIM & NÃO SABE & NÃO SABE & SIM & NÃO SABE & NÃO \\
\hline & $\begin{array}{l}\text { Avaliação de risco transcendente ao } \\
\text { ambiente de valor da companhia } \\
\text { (interno), inlcuindo o ambiente de } \\
\text { negócio (externo). }\end{array}$ & 15 & \begin{tabular}{|l|} 
A AkzoNobel PPC avalia \\
seus riscos considerando \\
também o ambiente externo à \\
organização (ver figura \\
Riscos Empresariais no \\
Ambiente de Valor)?
\end{tabular} & SIM & SIM & $\begin{array}{l}\text { PARCIALM } \\
\text { ENTE }\end{array}$ & SIM & NÃO SABE & SIM & \begin{tabular}{|l|} 
PARCIALM \\
ENTE
\end{tabular} & NÃO \\
\hline
\end{tabular}

